\title{
TAXONOMY AND PHYLOGENY
}

\section{OF LEAF MONKEYS (COLOBINAE)}

WITH FOCUS ON THE GENUS

PRESBYTIS (ESCHSCHOLTZ, 1821)

Dissertation zur Erlangung des akademischen Grades Dr. rer. nat. der Mathematisch-Naturwissenschaftlichen Fakultäten der Georg-August-Universität zu Göttingen

vorgelegt von

Dipl.-Biol.

Dirk Meyer

aus

Berlin 
Referent: Prof. Dr. J. Keith Hodges

Koreferent: Prof. Dr. Julia Fischer

vorgelegt von: Dipl.-Biol. Dirk Meyer

Tag der mündlichen Prüfung: 


\section{Summary}

Leaf monkeys (Colobinea) constitute a very diverse group of primates with major radiations in Africa and Asia. The Asian colobines are tradionally divided into the oddnosed group (Simias, Nasalis, Pygathrix, Rhinopithecus) and the langur group (Semnopithecus, Trachypithecus, Presbytis). Among the langur group Presbytis constitutes a particular diverse taxon, but the phylogenetic position of Presbytis among the Asian colobines, as well as the number of Presbytis taxa and their phylogenetic relationships remain controversial.

Previous molecular studies on leaf monkeys on the generic level based on incomplete sampling and revealed discordant gene trees for the Asian group. In particular the phylogenetic position of Presbytis was unclear. In a comperative genetic approach, we combined presence/absence analysis of mobile elements with autosomal, $\mathrm{X}$ chromosomal, $Y$ chromosomal and mitochondrial sequence data from all recognized colobine genera. Our results could not clarify the phylogenetic position of Presbytis, but indicated an unidirectional gene flow from Semnopithecus into Trachypithecus via male introgression, rather than a previously proposed hybridization between Presbytis and Trachypithecus.

Regarding the genus Presbytis, almost all current classifications predominantly based on morphological traits, while the only molecular study relied heavily on captive animals of uncertain origin. Therefore during two extended field surveys on Java, Sumatra and the Mentawai Islands, fecal and acoustic samples of more than 30 wild Presbytis populations were collected and subsequently analysed. Phylogenetic reconstructions based on a $1.8 \mathrm{~kb}$ long fragment of the mitochondrial genome and revealed various well-supported terminal clades, which refer mainly to the described taxa. The P.melalophos group emerged as paraphyletic, which was strongly supported by a structural analysis of 100 male loud-calls. This enabled us to propose a revised classification of the P.m.melalophos group. Furthermore and in concordance with the com- 
plex geographic distribution of Presbytis, we found a highly significant correlation between call structure and genetic similarity, and lesser significant correlations between call structure and geographic distance, and genetic similarity and geographic distance. Based on divergence time estimates we detected two periods of radiation, the first during the late Miocene and the second during the late Pliocene/early Pleistocene. Previous phylogeographic hypothesis based predominantly on a proposed basal position of P.potenziani from the Mentawai Islands. Our results however indicated that these morphological features might be pleisiomorphic. In our phylogenetic reconstruction P.thomasi is the sister to the remaining taxa. P.thomasi most likely evolved on the Asian mainland, while P.potenziani diverged during the second phase of radiation. The general sympatry of Presbytis on Borneo is at least to some extend the result of a second colonization of the island during the Pleistocene. 


\section{Ringkasan}

Monyet daun (Colobinea) mewakili kelompok primata yang sangat beragam dengan radiasi/sebaran utama di Afrika dan Asia. Colobine Asia secara tradisional terdiri dari kelompok berhidung aneh [odd-nosed] (Simias, Nasalis, Pygathrix, Rhinopithecus) dan kelompok langur (Semnopithecus, Trachypithecus, Presbytis). Diantara kelompok langur, Presbytis mewakili sejumlah takson yang beragam, tetapi posisi filogenetik Presbytis diantara colobine asia maupun jumlah taksa Presbytis dan hubungan filogenetik mereka-hingga saat ini- masih kontroversial.

Studi molekuler terdahulu tentang monyet daun pada tingkatan generik berdasarkan sampling yang tidak lengkap dan mengungkapkan pohon gen yang tidak sesuai untuk kelompok Asia. Secara khusus adalah tidak jelasnya posisi filogenetik Presbytis. Dalam pendekatan genetis komparatif, kami menggabungkan kehadiran/ketidakhadiran analisa elemen bergerak dengan autosomal, kromosom $\mathrm{X}$, kromosom $\mathrm{Y}$ dan data sekuensi mitokondrial dari semua genera colobine yang bisa dikenali. Hasil kami tidak dapat mengklarifikasi posisi filogenetik Presbytis, tetapi mengindikasikan aliran gen searah dari Semnopithecus ke Trachypithecus melalui introgesi jantan, berbeda dari usulan sebelumnya tentang hibridisasi (persilangan) antara Presbytis dan Trachypithecus.

Mengenai genus Presbytis sendiri, hampir semua pengelompokan terkini utamanya berdasarkan sifat morfologi, sementara satu-satunya studi molekuler sangat bergantung pada hewan tangkapan dari asal yang belum diketahui. Oleh karena itu, selama dua survey lapang lanjutan di Jawa, Sumatra dan Kepulauan Mentawai, contoh kotoran dan bunyi dari 30 populasi Presbytis liar telah dikumpulkan dan dianalisa secara berurutan. Rekonstruksi filogenetik berdasarkan pada fragmen sepanjang $1.8 \mathrm{~kb}$ dari genom mitokondrial dan mengungkapkan beragam terminal klad yang cukup didukung, yang umumnya mengacu pada takson yang telah digambarkan. Kelompok $P$. melalophos muncul sebagai parafiletik, yang didukung secara kuat oleh analisa struktural dari 
100 suara panggilan keras jantan dewasa. Hal ini memungkinkan kami untuk mengajukan klasifikasi revisi dari kelompok P. m. melalophos. Lebih jauh dan berkaitan dengan penyebaran geografis kompleks Presbytis, kami menemukan korelasi yang sangat signifikan antara struktur panggilan dan kemiripan genetis, dan korelasi yang kurang signifikan antara struktur panggilan dan jarak geografis, dan kemiripan genetis dan jarak geografis. Berdasarkan perkiraan waktu divergen, kami mendeteksi dua periode radiasi, pertama pada masa akhir Miosen dan yang kedua pada akhir Pliosen/awal Pleistosen. Hipotesis filogeografi sebelumnya utamanya berdasarkan pada usulan posisi basal dari $P$. potenziani dari Kepulauan Mentawai. Namun hasil kami mengindikasikan bahwa fitur morfologis ini kemungkinan adalah plesiomorfis. Dalam rekonstruksi filogenetik kami $P$. thomasi adalah kerabat dari takson yang sudah ada. $P$. thomasi kemungkinan besar berevolusi di daratan Asia, sementara $P$. potenziani terdivergen saat fase kedua radiasi. Simpatri umum dari Presbytis di Borneo setidaknya merupakan hasil dari kolonisasi kedua dari pulau tersebut pada masa Pleistosen. 


\section{Table of Contents}

Summary $\quad$..........................................................................................

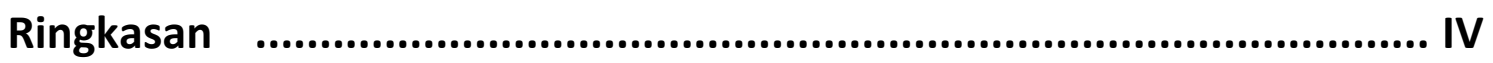

Chapter 1 General Introduction .........................................................1

1.1 Leaf monkeys (Colobinae) .................................................................

1.2 Surilis (genus Presbytis, Eschscholtz 1821) ..........................................4

1.2.1 Presbytis taxonomy............................................................6

1.2.2 Presbytis phylogeny and phylogeography ...............................8

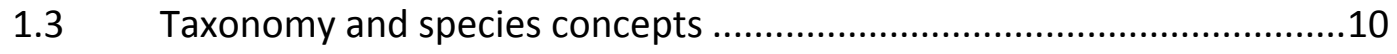

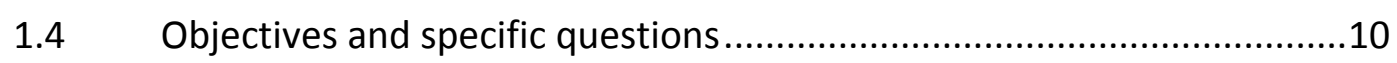

Chapter 2 Nuclear versus mitochondrial DNA: evidence for hybridization in Colobine monkeys ..................................14

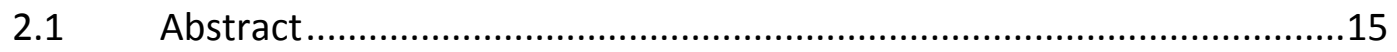

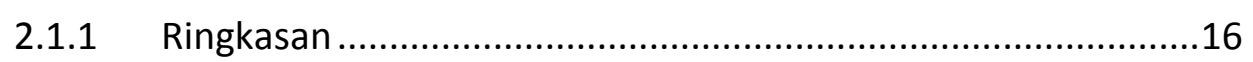

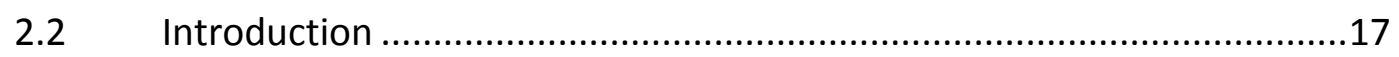

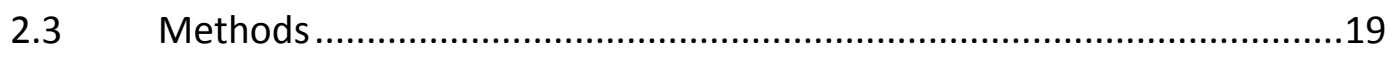

2.3.1 Sample collection and DNA extraction ...................................19

2.3.2 Analysis of mobile elements ..................................................19

2.3.3 Amplification and sequencing of nuclear loci.........................21

2.3.4 Amplification and sequencing of mitochondrial genomes........22

2.3.5 Statistical analysis of sequence data .....................................23

2.3.6 Divergence age estimation .....................................................24

2.3.7 Inferring hybridization in the presence of incomplete lineage

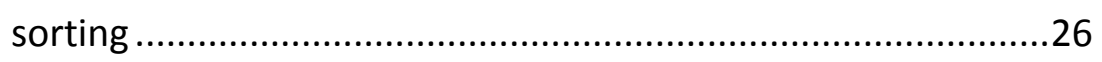

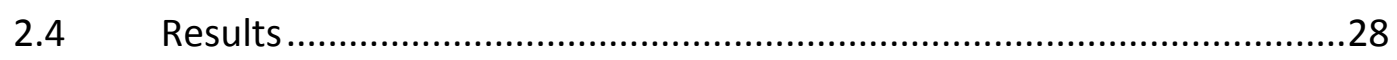

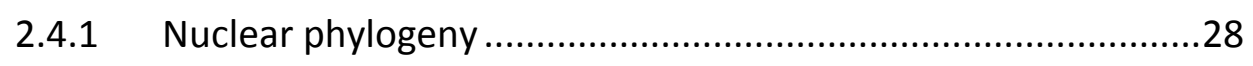

2.4.2 Mitochondrial phylogeny.......................................................30

2.4.3 Inferring hybridization in the presence of incomplete lineage

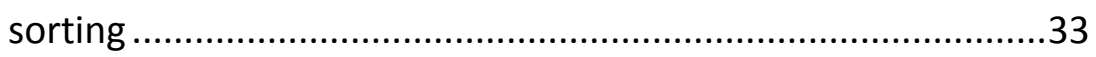

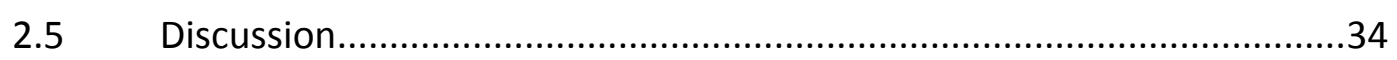

2.5.1 Possible explanations for gene tree discordance .....................34

2.5.2 Hybridization hypothesis .......................................................36 


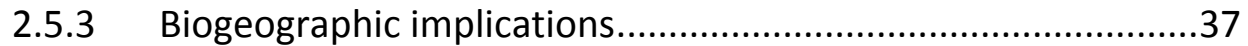

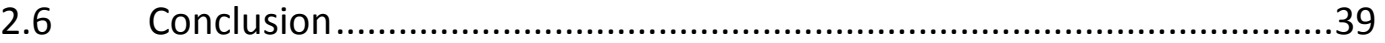

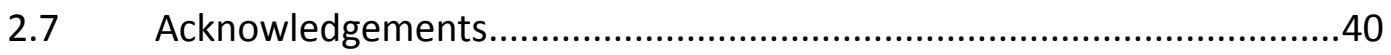

Chapter 3 Mitochondrial phylogeny of leaf monkeys (genus Presbytis, Eschscholtz, 1821) with implications for taxonomy and conservation ......................................................................42 42

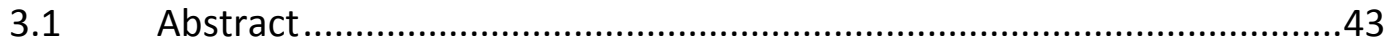

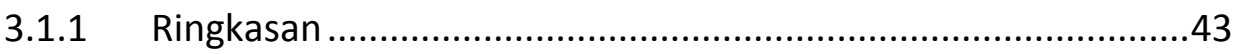

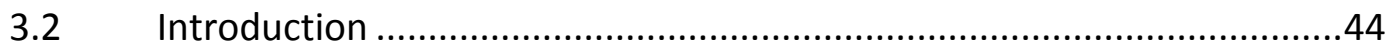

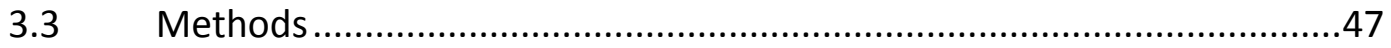

3.3.1 Sample collection ...............................................................4

3.3.2 Laboratory work .................................................................47

3.3.3 Statistical analysis ................................................................50

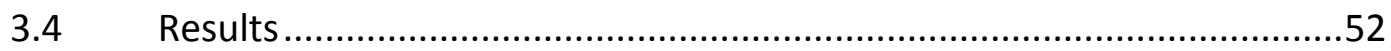

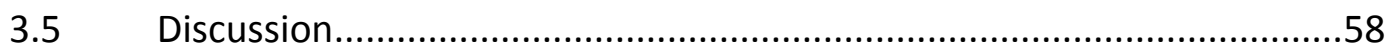

3.5.1 Phylogenetic relationships...................................................59

3.5.2 Taxonomic implications .....................................................62

3.5.3 Conservation implications ....................................................63

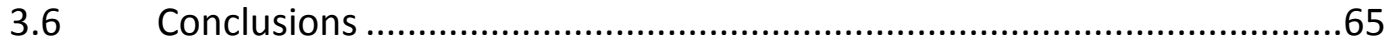

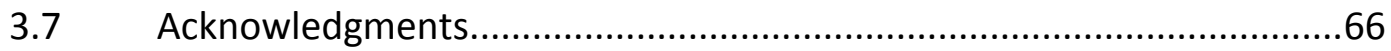

Chapter 4 Acoustic structure of male loud-calls support molecular phylogeny of Sumatran and Javanese leaf monkeys (genus

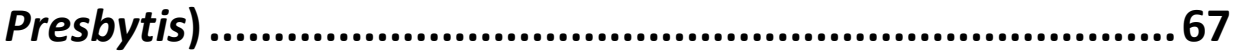

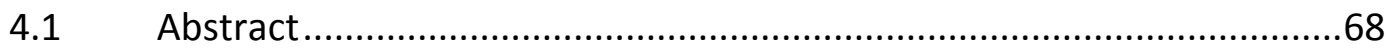

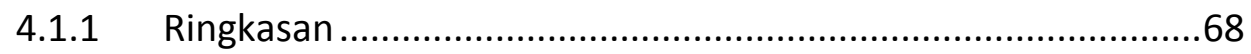

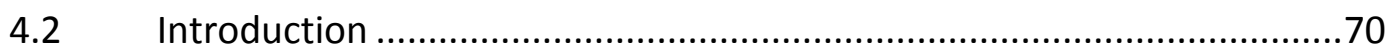

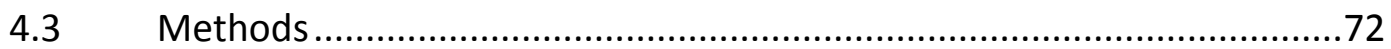

4.3.1 Survey locations and data collection .....................................72

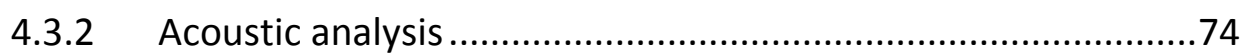

4.3.3 Discriminant Function Analysis ............................................77

4.3.4 Phylogenetic tree reconstruction ............................................78

4.3.5 Correlation analysis between vocal structure, genetic and geographical distance ........................................................78

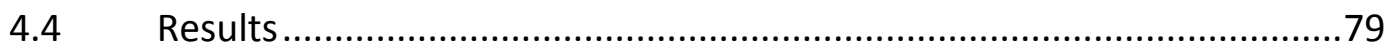


4.4.1 General differences in male loud-calls .................................79

4.4.2 Subtle differences in male loud-calls.......................................80

4.4.3 Correlation between vocal structure, genetic and geographical distance.

4.4.4 Phylogenetic relationships among Presbytis taxa based on acoustic data and comparison with molecular data .................85

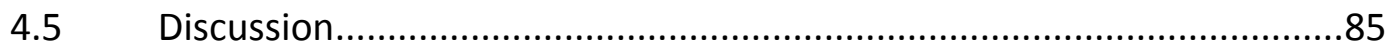

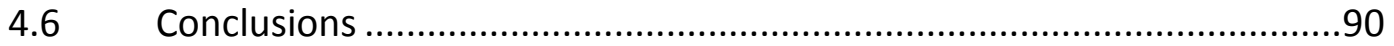

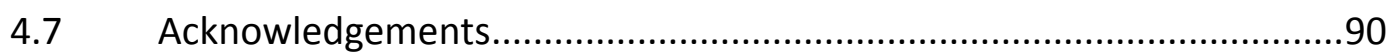

Chapter 5 General discussion ................................................ 92

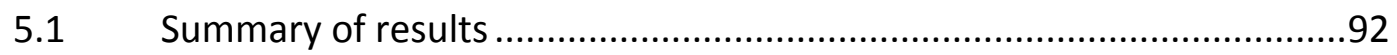

5.2 Consideration of the major results ....................................................96

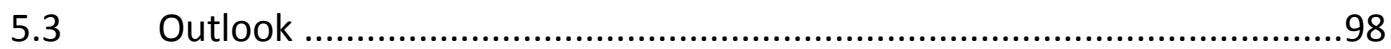

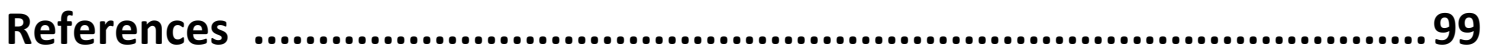

Appendix $\quad$........................................................................... 114

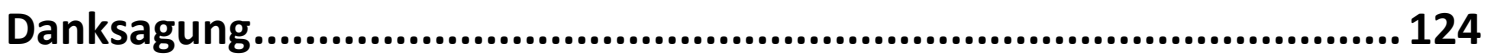

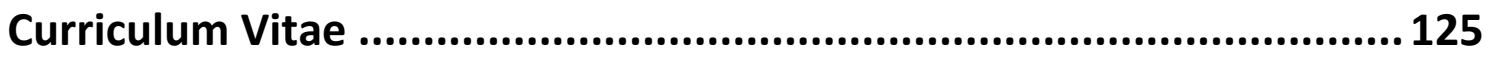

Eidesstattliche Erklärung ....................................................... 127 


\section{List of Tables}

Table 1.1: Arrangement of the classifications of Groves (2001) and Brandon-Jones et al. (2004) 7

Table 2.1: Origin and sample type of studied species 20

Table 2.2: Estimation of divergence ages in mya (95\% highest posterior density) ....... 32

Table 3.1: Details on the Presbytis samples used in this study.................................. 48

Table 3.2: Information about primers used in this study. ....................................... 50

Table 3.3: Bayesian divergence date estimates ....................................................... 59

Table 3.4: Proposed classification compared to earlier classifications along with information about type localities, authors and conservation status............................6 64

Table 4.1: Description of the used 23 acoustic parameters ...................................... 75

Table 4.2: Classification results of the first and second Discriminant Function Analysis in relation to the taxon membership 82

\section{List of Figures}

Figure 1.1: Illustrations of colobine monkey genera 3

Figure 1.2: Present distribution range of Presbytis.

Figure 2.1: Phylogenetic relationships among colobine and outgroup genera as inferred from insertions of mobile elements, combined nuclear sequence data, and mitochondrial genome data.

Figure 2.2: The nine alternative hybridization scenarios compared in the coalescent framework 27

Figure 2.3: Dispersal scenario for colobine monkeys ..................................................... 38

Figure 3.1: Origin of the fecal samples in a distribution map of Presbytis .................... 46

Figure 3.2: Phylogenetic reconstruction based on mtDNA sequence data. 54

Figure 3.3: Ultrametric tree and estimated divergence ages among studied Presbytis individuals 57

Figure 4.1: Origin of the acoustic samples in a distribution map of Presbytis. 73 
Figure 4.2: Spectrograms of typical loud-calls of P.thomasi, P.potenziani, P.comata and P.melalophos. 76

Figure 4.3: Spectrogram of a Presbytis loud-call with examples for the measured parameters. 77

Figure 4.4: Spectrograms of typical loud-calls of P.melalophos subspecies. 81

Figure 4.5: Distributions of the different populations in scatterplots of the Discriminant Function Analysis 1 (DFA 1) and DFA 2. 83

Figure 4.6: Neighbor-joining tree of Presbytis taxa based on an acoustic similarity matrix ( $F$ values) and their phylogenetic relationships according to mitochondrial sequence data 86

\section{List of Appendices}

Additional File 1: Presence/absence pattern, location, primers and PCR product sizes of mobile elements (Chapter 2) 114

Additional File 2: Primers and PCR conditions for the amplification of nuclear loci (Chapter 2).

Additional File 3: GenBank accession numbers. Sequences in italic are taken from GenBank (Chapter 2)

Additional File 4: Single-locus phylogenetic trees (Chapter 2). 118

Additional File 5: Divergence ages for each locus separately (Chapter 2) 119

Additional File 6: Descriptive statistics to the measured parameters (Chapter 4) ..... 121

Additional File 7: Photographs of Presbytis taxa 


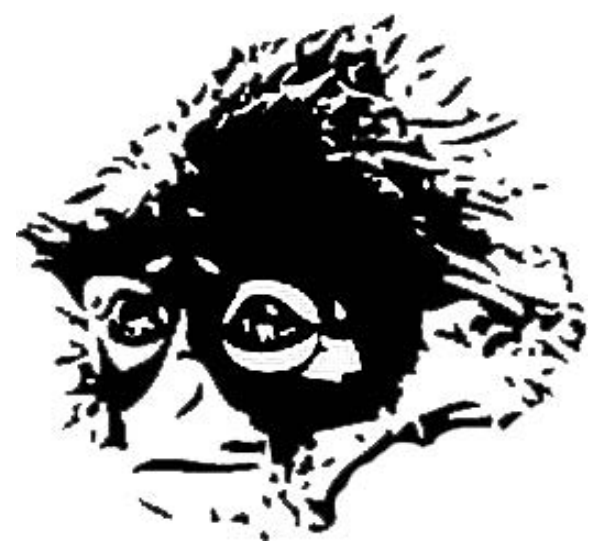

"While wandering a deserted beach at dawn, stagnant in my work, I saw a man in the distance bending and throwing as he walked the endless stretch toward me. As he came near, I could see that he was throwing starfish, abandoned on the sand by the tide, back into the sea. When he was close enough I asked him why he was working so hard at this strange task. He said that the sun would dry the starfish and they would die. I said to him that I thought he was foolish. There were thousands of starfish on miles and miles of beach. One man alone could never make a difference. He smiled as he picked up the next starfish. Hurling it far into the sea he said, "It makes a difference for this one." I abandoned my writing and spent the morning throwing starfish." 



\section{Chapter 1 General Introduction}

With more than 630 currently described taxa, the primate order is one of the most diverse and successful group of mammals (Groves 2004; Mittermeier et al. 2009; Rowe and Myers 2011). Over the course of their evolutionary history, non-human primates display great diversity of behavioral and morphological traits (Smuts 1987). With the exception of Antarctica, non-human primates have been documented on every major continent colonized by placental mammals (Rowe and Myers 2011).

\subsection{Leaf monkeys (Colobinae)}

According to Groves (2001) the Old World Monkey family Cercopithecidae is divided into two subfamilies, the Cercopithecinae (Cheek Pouch Monkeys) and the Colobinae (Leaf monkeys). In contrast to the Cercopithecinae, the Colobinae are particularly distinguished by the presence of a ruminant-like chambered stomach, unique among primates (Napier and Napier 1967; Oates and Davies 1994). The complexity of their stomach is partly a response to the chemical problems in digesting leaves, that contain much fiber and other secondary components, as well as to neutralize the effects of inhibitors and toxins (Chivers 1994; Strasser and Delson 1987). Other key anatomical characters are also related to food processing, for instance greatly enlarged salivary glands (Davies and Oates 1994), and the morphology of their teeth (Lucas and Teaford 1994). Colobines get their name from very short or absent thumbs of the African species (Greek kolobos, mutilated), whereas Asian colobines have a small thumb (Oates and Davies 1994). Typically the hindlimbs of colobines are much longer than the forelimbs (Strasser 1992) and almost all colobines have long tails (Oates and Davies 1994). These postcranial characters are proposed to be related to the colobine monkey commitment to arborality and leaping (Strasser 1992).

Colobines show a great diversity in the social organizations of their societies. Reported are matrilinial - harems (e.g. Colobus guereza, Trachypithecus obscurus, Presbytis me- 
lalophos, Nasalis larvatus, Semnopithecus entellus), matriliniael - multi-male societies (e.g. Colobus satanas, Nasalis larvatus, Semnopithecus entellus), patrilineal - multimale societies (e.g. Piliocolobus badius, Procolobus verus) and even monogamy (e.g. Presbytis potenziani) (Newton and Dunbar 1994; Tilson 1976b; Watanabe 1981). Variations in other aspects of colobine social life, such as grooming patterns, sexual swellings, flamboyant natal coats, nurtureing behavior and infanticide are probably linked to this variation in social organization (Clutton Brock and Harvey 1977; Newton and Dunbar 1994).

Tradionally behavioral patterns, in particular anatomical traits were used to propose working classifications. Taxonomy always was, and still is a very dynamic and controversially discussed scientific discipline. With increasing knowledge over the past decades and since molecular genetic methods were applied more often in order to draw taxonomic and phylogenetic conclusions, it is not surprising that colobine monkeys have a long history of taxonomic revisions. They have been grouped into between four and ten genera (Delson et al. 1982; Groves 2001; Napier and Napier 1967; Napier 1985; Oates et al. 1994; Szalay and Delson 1979; Thorington Jr and Groves 1970).

I will follow the classification of Groves (2001), who further divided the colobines themselves into two groups: an African group with the genera Colobus, Procolobus and Piliocolobus, and an Asian group comprising the langur genera Semnopithecus, Trachypithecus and Presbytis, and the odd-nosed monkey genera (which were named after their unusual nose morphology) Rhinopithecus, Pygathrix, Nasalis and Simias (Figure 1.1). 


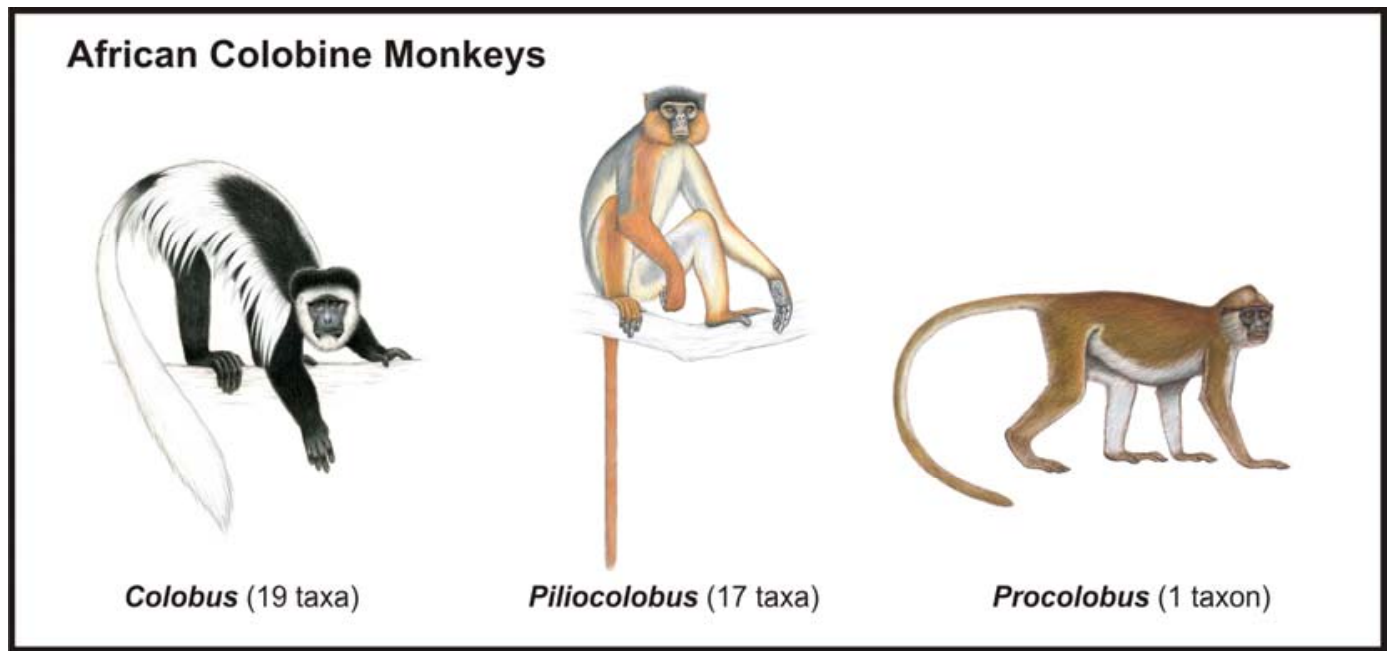

\section{Asian Colobine Monkeys}
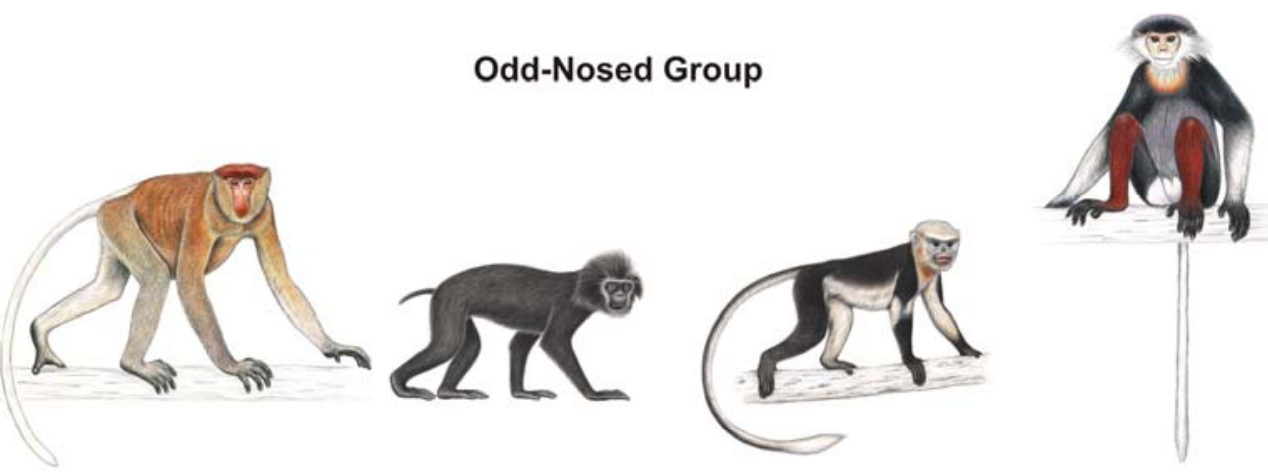

Nasalis (1 taxon)

Simias (1 taxon)

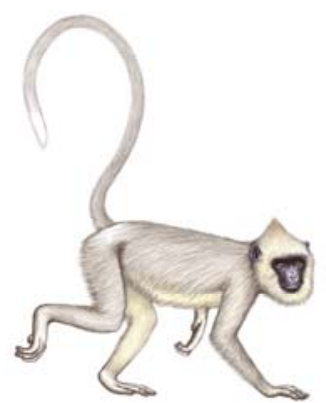

Semnopithecus (8 taxa)

Langur Group

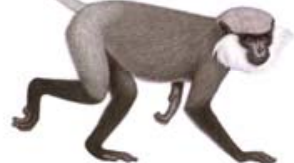

Trachypithecus (34 taxa)

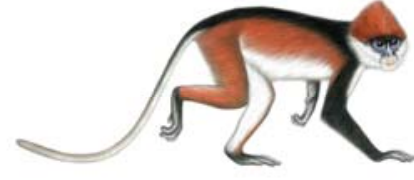

Presbytis (31 taxa)

Figure 1.1: Illustrations of colobine monkey genera (classification based on Groves 2001; Illustrations used with permission by Stephen D. Nash I Conservation international. Copyright 2011) 
The monophyly of the Asian and African groups is supported by molecular genetic data, but based on incomplete sampling (Osterholz et al. 2008; Sterner et al. 2006; Ting et al. 2008).

Within the Asian group, genetic studies indicate conflicting phylogenetic relationships between langur genera in relation to mitochondrial and nuclear data. Mitochondrial data either support a sister grouping of Presbytis and Trachypithecus (Sterner et al. 2006) or do not resolve langur relationships in general (Osterholz et al. 2008). Xchromosomal data however place Presbytis as sister to all Asian colobines, and support a sister grouping of Trachypithecus and Semnopithecus. This could be explained by introgressive hybridization (Ting et al. 2008).

\subsection{Surilis (genus Presbytis, Eschscholtz 1821)}

Compared to Trachypithecus, Presbytis has longer hind limbs, leaps more, uses less quadrupedalism (Fleagle 1977; Strasser 1992) and has a smaller stomach (Chivers 1994). Leaves contribute less than $40 \%$ in some Presbytis diet (i.e. in rubicunda, siamensis, hosei) (Chivers 1994) which mainly consists of seeds and fruits (Bennett and Davies 1994), whereas foliage nutrition constitutes more than 60\% in Trachypithecus (Chivers 1994). Neonates of Trachypithecus are orange, while newborn Presbytis are white or whitish and as the coat darkens during development they pass through a stage that displays a cruciform pattern on the back and upper head (Pocock 1928).

The majority of Presbytis live in matrilineal (or female bonded) uni-male groups (Newton and Dunbar 1994). Only P.potenziani is reported to live partly monogamous (Tilson 1976b; Watanabe 1981) and P.thomasi forms matrilineal uni-male or multi-male groups (Newton and Dunbar 1994).

The geographical range of Presbytis is confined to Sundaland, which includes the Malay peninsular and the western Indo-Malay archipelago consisting of Borneo, Sumatra, Java, the Natuna Islands and the Mentawai Islands (Brandon-Jones et al. 2004; Groves 2001)(Figure 1.2). 


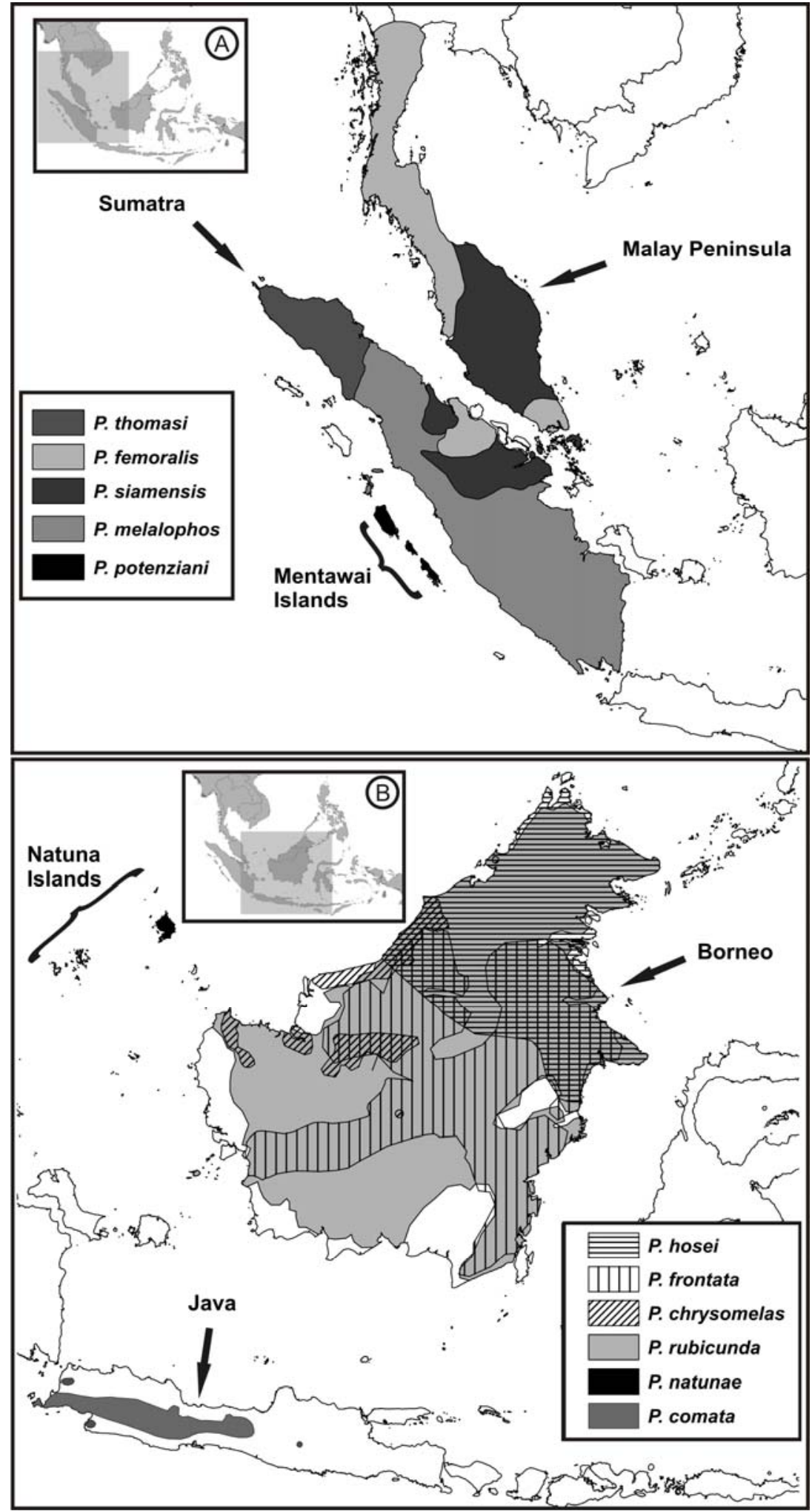

Figure 1.2: Present distribution range of Presbytis on the Asian Mainland, Sumatra and the Mentawai Islands (A) and on Borneo, Java and the Natuna Islands (B) (Groves 2001). 


\subsubsection{Presbytis taxonomy}

Presbytis is one of the most diverse primate genera. Since 1821 more than 50 Presbytis color-morphs have been described (Brandon-Jones et al. 2004; Groves 2001). Based on morphological features, i.e. natal pelage color, body weight or body length Napier \& Napier (1967) proposed 4 Presbytis species groups, with 14 species. Currently however, only seven are still considered as members of the genus (Brandon-Jones et al. 2004; Groves 2001).

The taxonomy of Presbytis continued to be unclear with subsequent studies dividing the genus into either four (Wolfheim 1983), seven (Brandon-Jones 1984; Groves 1970; Medway 1970; Oates et al. 1994) or eight (Corbet and Hill 1992; Weitzel et al. 1988) species according to various interpretations of anatomical, ecological and behavioral data. A few studies also used phonetic descriptions of male vocalizations as a tool to propose the separation of respective taxa or phylogenetic relationships. Based on onephrase, two-phrase or three-phrase vocalizations, Sumatran langurs were divided into distinct species (Aimi and Bakar 1992; Wilson and Wilson 1976; Wilson and Wilson 1975) and a close affiliation of the Mentawai langur (P.potenziani) with the Thomas's langur (P.thomasi) was suggested (Wilson and Wilson 1976).

Most recent studies led Groves (2001) and Brandon-Jones et al. (2004) to propose a revised classification resulting in 11 and 10 species respectively. Although the authors agree on the species status of P.melalophos, P.thomasi, P.potenziani, P.siamensis, P.femoralis, P.comata, P.frontata, P.hosei and P.rubicunda, major differences in their classifications still exist (Table 1.1). These differences exist on the level of species and subspecies, even the validity of some taxa is disputed (synonyms). Furthermore, although Brandon-Jones et al. (2004) divided P.comata, P.thomasi and P.hosei as single species (which stands in accordance with Groves 2001), the authors still refer to a polytypic species concept (Brandon-Jones 1978, 1996c). According to this concept thomasi and hosei are conspecifics of P.comata.

To date, the only molecular genetic study addressing the Presbytis taxonomy and phylogeny came out by Md Zain (2001). Using mitochondrial, Y-chromosomal and auto- 
somal markers, he suggested that P.melalophos might be a single highly polytypic species with numerous subspecies, including P.femoralis, P.siamensis and P.natunae.

Table 1.1: Arrangement of the classifications of Groves (2001) and Brandon-Jones et al. (2004). Bold letters indicate species. * possibly referable to Presbytis comata (BrandonJones 1978, 1996c).

\begin{tabular}{|ll|l|}
\hline Taxon & Groves (2001) & Brandon-Jones et al. (2004) \\
\hline potenziani & P.potenziani potenziani & P.potenziani potenziani \\
\hline siberu & P.p.siberu & P.p.siberu \\
\hline thomasi & P.thomasi & P.thomasi \\
\hline melalophos & P.m.melalophos & P.m.melalophos \\
\hline mitrata & P.m.mitrata & P.m.mitrata \\
\hline bicolor & P.m.bicolor & P.m.bicolor \\
\hline sumatrana & P.m.sumatrana & \multicolumn{1}{c|}{ synonym of melalophos } \\
\hline nobilis & \multicolumn{1}{|c|}{ synonym of melalophos } & P.m.nobilis \\
\hline siamensis & P.siamensis siamensis & P.siamensis siamensis \\
\hline paenulata & P.s.paenulata & P.s.paenulata \\
\hline cana & P.s.cana & P.s.cana \\
\hline rhionis & P.s.rhionis & P.s.rhionis \\
\hline natunae & P.natunae & P.s.natunae \\
\hline femoralis & P.femoralis femoralis & P.femoralis femoralis \\
\hline robinsoni & P.f.robinsoni & P.f.robinsoni \\
\hline percura & P.f.percura & P.f.percura \\
\hline batuana & \multicolumn{1}{|c|}{ synonym of sumatrana } & P.f.batuana \\
\hline chrysomelas & P.chrysomelas chrysomelas & P.f.chrysomelas \\
\hline cruciger & P.c.cruciger & P.f.cruciger \\
\hline comata & P.comata comata & P.comata \\
\hline fredericae & P.c.fredericae & P.fredericae \\
\hline frontata & P.frontata & P.frontata \\
\hline hosei & P.hosei hosei & P.hosei hosei * \\
\hline sabana & P.h.sabana & P.h.sabana * \\
\hline everetti & P.h.everetti & P.h.everetti * \\
\hline canicrus & P.h.canicrus & P.h.canicrus * \\
\hline rubicunda & P.rubicunda rubicunda & P.rubicunda rubicunda \\
\hline chrysea & P.r.chrysea & P.r.chrysea \\
\hline carimatae & P.r.carimatae & P.r.carimatae \\
\hline ignita & P.r.ignita & P.r.ignita \\
\hline rubida & P.r.rubida & \multicolumn{1}{c|}{ synonym of carimatae } \\
\hline
\end{tabular}

In summary, therefore the taxonomy of the genus Presbytis remains unresolved. Many different classifications have been proposed over the past 40 years and the recent trend is that the taxon has become more and more speciose, but no final agreement 
on Presbytis taxonomy could be reached to date - neither on the level of species nor subspecies.

\subsubsection{Presbytis phylogeny and phylogeography}

Previous divergence time estimates suggest that the Presbytis ancestor have colonized Sundaland at the end of the Miocene (Sterner et al. 2006). During that geological period and also subsequently during the Pliocene and Pleistocene, Sundaland was affected by dramatic changes in geology (Barry et al. 1985; van Bemmelen 1970), fluctuation in ocean levels (Haq et al. 1987; Miller et al. 2005) and changes in vegetation patterns (Cerling et al. 1997), which gave rise to a high degree of radiation (Meijaard 2004). As a result Presbytis represents one of the most diverse genera within the Old World Monkeys. Almost all evolutionary models on Presbytis that have been proposed so far, are predominantly based on anatomical features (Brandon-Jones 1978; Brandon-Jones 1996a; Groves 1989; Meijaard and Groves 2004) and only one model is derived from molecular genetic analysis (Md Zain 2001).

According to Md Zains' (2001) phylogeographic model proto-Presbytis underwent two cladogenic events on Borneo. The first separated the proto-Presbytis into a hosei like form and an intersectional Presbytis. The latter underwent a further subdivision into a melalophos like - and a comata / thomasi / rubicunda like form. This dispersal pattern is opposite to the direction of events proposed by previous studies of Meijaard and Groves (2004), Groves (1989) and Brandon-Jones (1978; 1996a).

In Brandon-Jones's (1978; 1996a) reconstruction, P.potenziani represents the most primitive form with its dark coat coloration. P.potenziani evolved during the middle Miocene where it was restricted to the Mentawai Islands during a severe glaciation. After this glaciation stage P.comata splitted from P.potenziani. During a subsequent glacial period P.comata, with a greyish pelage colour, was restricted to glacial refugias in northern Sumatra (thomasi), West Java (comata) and Borneo (hosei). From the Sumatran population two branches dispersed. One branch dispersed to the southern tip of the island (femoralis and melalophos) and another migrated to the Malay Peninsular 
(siamensis) and Northwest Borneo (frontata). Furthermore Brandon-Jones (1996b) proposed a close affinity between P.rubicunda and P.melalophos in terms of behavioral characters. Thus P.melalophos, P.femoralis, P.frontata and P.rubicunda represent the most derived forms in Brandon-Jones's model of coat coloration, all with red/brown pelage coloration.

According to the principles of the metachromism model of Hershkovitz (1968), where coat colours advance from a primitive agouti pattern via blackish / brown to more derived colours like red or white (but see Lawlor 1969), Groves (1989) proposed his centrifugal speciation hypothesis for Presbytis. With regards to the basal position of P.potenziani he agreed with Brandon-Jones. In Groves' model, the greyish taxa comata, thomasi and hosei, which evolved from the black P.potenziani, are found at the periphery of the present geographical range of the genus. The derived red / brown forms are central in distribution (melalophos, femoralis, frontata, rubicunda).

Based on the models of Brandon-Jones and Zain, while additionally analysing craniometrical data, Meijaard and Groves (2004) proposed that an ancestral species crossed Sumatra, Java and Borneo during an early/middle Pleistocene glacial period. In contrast to the model of Brandon Jones, Meijaard and Groves' hypothesis claims that the ancestral potenziani evolved on Sumatra and spread to the Mentawai islands. P.potenziani subsequently became extinct on mainland Sumatra. Furthermore they suggested an early split of thomasi from a previous form. In addition to that and as a direct result of the dispersal of its ancestor, P.melalophos evolved exclusively on Sumatra in their model.

In summary, Meijaard, Groves and Brandon-Jones agree about the basal phylogenetic position of P.potenziani based on craniometrical data and on coat colouration respectively. In marked contrast to the other models, Zains' results show a dispersal pattern of the genus which is opposite to the direction of all other reconstructions. 


\subsection{Taxonomy and species concepts}

Species are the units of classification, biogeography and conservation; as they must be defined as objectively as possible (De Queiroz 2005; Groves 2004). Every classification is a hypothesis, which relies not only on the type and quantity of data available, but also on a framework, called "species concept" (Groeneveld 2008). The question "What is a species?" is maybe one of the most controversial discussed issues in biology. It is not the aim of this study to discuss pros and cons of certain species concepts, but we had to decide for a framework based on which we could draw our taxonomic conclusions. The tradional Biological Species Concept (BSC) by Mayr (1963) is proven to be insufficient (De Queiroz 2007). If two populations are sympatric and maintain their separateness, this is of course evidence that they are distinct species and the BSC applies well. But as mentioned above, many populations of Presbytis are allopatric and this is the critical argument, where the BSC leaves the vast majority of the natural world unclassifiable (Groves 2004). Therefore we will apply the so called "Phylogenetic Species Concept" (PSC) proposed by Cracraft $(1983,1989)$, which defines a species as "the smallest cluster of individual organisms within there is a parental pattern of ancestry and descent and that is diagnosbly distinct from other such clusters by a unique combination of fixed character states". The major advantages are 1) that the PSC is completely objective and therefore falsifiable, 2) it is free of speculations about mechanisms of speciation, even in the case of species of hybrid origin and 3) the recognition of species depends on whether the differences are fixed, not on the degree or amount of differences (Groves 2004). This might be the reason why the PSC is widely applied in most recent studies on primate taxonomy, for instance in Callicebus (van Roosmalen et al. 2002), Saguinus (Matauschek et al. 2011), Microcebus or Lepilemur (Russell et al. 2010; Tattersall 2007).

\subsection{Objectives and specific questions}

With eight species listed among the 25 most endangered primates in the world, almost one third are colobine monkeys (Mittermeier et al. 2009), hence it is suprising, that 
colobines still receive much less scientific attention as opposed to other primates, especially their close cercopithecine relatives and the apes (Davies and Oates 1994). Their neglect relative to cercopithecines since the early 1960 s is probably partly a consequence of some of their ecological differences. In contrast to cercopithecines, the great majority of colobines live in moist forests, in which observational studies are more difficult than in more open woodland or savanna habitats. Additionally many colobine populations occur in countries that have presented serious political or logistical obstacles to field research (Davies and Oates 1994).

Regarding Presbytis phylogeny and taxonomy, there is a particular lack of knowledge. As mentioned above, almost all previous studies are mainly based on anatomical features, while molecular genetic studies are extremely limited and relied heavily on samples of captive animals. Furthermore the majority of Presbytis taxa live in Indonesian territories and were to date not adequately addressed. For instance genetic data on key taxa such as P.potenziani, which are crucial for the reconstruction and understanding of Presbytis phylogeny, are completely lacking. Therefore, and from the above outlined state of art the present study was designed with the overall goal to clarify colobine monkey taxonomy, phylogeny and phylogeography with particular emphasis on the genus Presbytis. I conducted two comprehensive field surveys on Java, Sumatra and the Mentawai Islands. During a period of 13 month I collected fecal samples for genetic analysis and recorded male loud-calls for an acoustic study of wild nonhabituated Presbytis populations. Additionally I collected fecal samples from captive animals and tissue samples of museum specimen. In total I achieved samples of more than 30 locations representing eight of the ten species (Groves 2001). The following main questions arose and are addressed in this dissertation: newly collected data from the field were used to answer the following questions:

1. What can be concluded from the re-examination of the leaf monkey phylogeny regarding Presbytis?

- What is the phylogenetic position of Presbytis among the Asian colobines? 
- Does the colobine monkey phylogeny support a possible hybridization between Presbytis and Trachypithecus, or between Semnopithecus and Trachypithecus (Ting et al. 2008)?

2. Are previous classifications of Presbytis supported by new acoustic and genetic data from the field?

- Is P.comata a polytypitc species group (Brandon-Jones 1978, 1996c)?

- Is P.melalophos a polytypic species group (Md Zain 2001)?

- Is there a conspecific relationship between P.potenziani and P.thomasi (Wilson and Wilson 1976)?

3. Can existing phylogeographic hypothesis of Presbytis be supported by divergence time estimates and a reassessed phylogeny of the genus?

- When did the genus Presbytis evolve?

- Do our results support an east/west (Brandon-Jones 1978; Brandon-Jones 1996a; Meijaard and Groves 2004) or a west/east dispersal pattern of Presbytis (Md Zain 2001)?

- Are there any explanations for Presbytis' allopatry on Sumatra and sympatry on Borneo?

The following chapters address the above mentioned main questions:

Chapter 2 gives insights into the phylogenetic relationships between colobine monkey genera on a broader scale. To address the first main question, a presence/absence analysis of mobile elements is combined with the analysis of autosomal, Xchromosomal, Y-chromosomal and complete mitochondrial genome sequence data derived from samples of all recognized colobine monkey genera. Additionally divergence time estimates of all taxa are calculated. The following Chapters focus on the genus Presbytis. To address the second and third main questions, two different ap- 
proaches are used: A molecular genetic approach (chapter 3 ) and an acoustic approach (chapter 4). Chapter 3 deals with the mitochondrial phylogeny of Presbytis based on a sequence data analysis of the cytochrome $b$ and the hypervariable region I. Aditionally divergence time estimates were calculated for all taxa. In Chapter 4 acoustic data in combination with genetic data is used to reassess our findings of chapter 3 , based on a detailed structural analysis of male loud-calls and correlations between acoustic, genetic and geographic distances. 


\title{
Chapter 2 Nuclear versus mitochondrial DNA: evidence for hybridization in Colobine monkeys
}

\section{Nuclear versus mitochondrial DNA: evidence for hybridization in colobine monkeys}

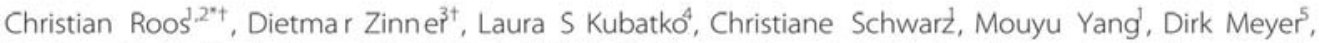
Stephen D Nash', Jinchuan Xing, Mark A Batzer, Markus Brameier', Fabian H Leendertzి, Thomas Ziegle?, Dyah Perwitasa ri-Farajallah ${ }^{0}$, Tilo Nadler ${ }^{11}$, Lutz Walter ${ }^{1,2}$, Martin Osterh olz.,12*

\section{Abstract}

Background: Colobine monkeys constitute a diverse group of primates with major radiations in Africa and Asia However, phylogenetic relationships among genera are under debate, and recent molecular studies with incomplete taxon-sampling revealed discordant gene trees. To solve the evolutionary history of colobine genera and to determine causes for possible gene tree incongruences, we combined presence/absence analysis of mobile elements with autosomal, $\mathrm{X}$ chromosomal, $\mathrm{Y}$ chromosomal and mitochondrial sequence data from all recognized colobine genera.

Results:Gene tree topologies and divergence age estimates derived from different markers were similar, but differed in placing Piliocolobus/Procolobusand langur genera among colobines. Although insufficient data, homoplasy and incomplete lineage sorting might all have contributed to the discordance among gene trees, hybridization is favored as the main cause of the observed discordance. We propose that African colobines are paraphyletic, but might later have experienced female introgression from Piliocolobus/ProcolobusintoColobus . In the late Miocene, colobines invaded Eurasia and diversified into several lineages. Among Asian colobines, Semnopithecusdiverged first, indicating langur paraphyly. However, unidirectional gene flow from Semnopithecus intoTrachypithecusvia male introgression followed by nuclear swamping might have occurred until the earliest Pleistocene

Conclusions: Overall, our study provides the most comprehensive view on colobine evolution to date and emphasizes that analyses of various molecular markers, such as mobile elements and sequence data from multiple loci, are crucial to better understand evolutionary relationships and to trace hybridization events. Our results also suggest that sex-specific dispersal patterns, promoted by a respective social organization of the species involved, can result in different hybridization scenarios.
\end{abstract}

\section{Author details}

'Primate Genetics Laboratory, German Primate Center, Kellnerweg 4, 3707 7 Göttingen, Germany. ${ }^{2}$ Gene Bank of Primates, German Primate Center, Kellnerweg 4, 37077 Göttingen, Germany. ${ }^{3}$ Cognitive Ethology Laboratory. German Primate Center, Kellnerweg 4, 37077 Göttingen, Germany. "Departments of Statistics and Evolution, Ecology and Organismat Biology. The Ohi State University, Col Evbus, Ohio 43210, USA 5 Reproductive The Ohio State University, Columbus, Ohio 43210, USA. SReproductive Germany. 'Department of Anatomical Sciences, State University of New York. Stony Brook, New York $11794-8081$, USA. Department of Human Genetics. University of Utah, 15 North 2030 East, Salt Lake City, Utah 84112, USA "Department of Biological Sciences, Louisiana State University, 202 Life Sciences Building, Baton Rouge, Louisiana 70803, USA. "Research Group Emerging Zoonoses, Robert Koch Institute, Postfach 650261, 13302 Berlin, Germany. "Primate Research Center and Department of Biology, Bogor Agricultural University, J. Lodaya 11/5, Bogor 16151, Indonesia. Frankfurt Zoological Society, Endangered Primate Rescue Center, Cuc Phuong Nation Park, Nho Quan District, Ninh Binh Province, Vietnam. 2 Stem Cell Biology Unit, German Primate Center, Kellnerweg 4, 37077 Göttingen, Germany.

\section{Acknowledgements}

We thank the zoos in Cologne, Dresden, Duisburg. Howletts, Munich, Nuremberg, Stuttgart and Wuppertal, and Roland Plesker and Werner Schempp for providing samples. We are also grateful to our colleagues at Bogor Agricultural University (IPB) and the Indonesian Institute for Science (LPI) as well as the Ivorian authorities, the Ministry of the Environment and Forests, the Ministry of Research, the directorship of Taï National Park and the Swiss Research Centre for providing the necessary field research permits and documents. No international and national rules and regulations have been violated during sampling and shipping. We thank Vanessa Roden, Laura Zidek, Linn Groeneveld, Daniel Stahl and two anonymous reviewers for valuable comments on an eartier version of the manuscript and statistical help. This work was supported by the German Primate Center and the Biodiversitats-Pakt of the Wissenschartsgemeinschaft Gottried-Withelm Leibniz to CR, DZ and LW, and by grants from the National Institutes of Health to MAB (RO1 GM59290) and JX (K99 HG005846). 


\subsection{Abstract}

Background: Colobine monkeys constitute a diverse group of primates with major radiations in Africa and Asia. However, phylogenetic relationships among genera are under debate, and recent molecular studies with incomplete taxon-sampling revealed discordant gene trees. To solve the evolutionary history of colobine genera and to determine causes for possible gene tree incongruences, we combined presence/absence analysis of mobile elements with autosomal, $\mathrm{X}$ chromosomal, $\mathrm{Y}$ chromosomal and mitochondrial sequence data from all recognized colobine genera.

Results: Gene tree topologies and divergence age estimates derived from different markers were similar, but differed in placing Piliocolobus/Procolobus and langur genera among colobines. Although insufficient data, homoplasy and incomplete lineage sorting might all have contributed to the discordance among gene trees, hybridization is favored as the main cause of the observed discordance. We propose that African colobines are paraphyletic, but might later have experienced female introgression from Piliocolobus/Procolobus into Colobus. In the late Miocene, colobines invaded Eurasia and diversified into several lineages. Among Asian colobines, Semnopithecus diverged first indicating langur paraphyly. However, unidirectional gene flow from Semnopithecus into Trachypithecus via male introgression followed by nuclear swamping might have occurred until the earliest Pleistocene.

Conclusions: Overall, our study provides the most comprehensive view on colobine evolution to date and emphasizes that analyses of various molecular markers, such as mobile elements and sequence data from multiple loci, are crucial to better understand evolutionary relationships and to trace hybridization events. Our results also suggest that sex-specific dispersal patterns, promoted by a respective social organization of the species involved, can result in different hybridization scenarios. 


\subsubsection{Ringkasan}

Latar Belakang: Monyet colobine terdiri atas kelompok berbagai jenis primata yang memiliki radiasi-radiasi utama di Afrika dan Asia. Namum denikian, hubungan filogenetik antara marga masih diperdebatkan, dan studi-studi molekuler dengan penarikan contoh taxon yang tidak lengkap mengungkapkan adanya pohon gen yang tidak harmonis. Untuk menjelaskan sejarah evolusi marga colobine dan menentukan penyebab dari kemungkinan adanya ketidaksamaan pohon genetik, kami mengombinasikan analisis presence/absence dari unsur-unsur begerak dengan autosomal, X chromosomal, Y chromosomal dan data sekuens mitokondria dari semua marga colobine yang sudah dikenal.

Hasil: Topologi pohon genetik dan dugaan umur divergensi diduga dari berbagai penanda yang sama, tetapi berbeda dalam penempatan Piliocolobus/Procolobus serta marga lutung di antara colobine. Meskipun data yang ada tidak mencukupi, homoplasi dan pemilahan garis keturunan kemungkinan berperan dalam ketidaksesuaian antara pohon genetik, hibridisasi dipilih sebagai penyebab utama ketidaksesuaian yang tampak. Menurut kami, colobine Afrika adalah paraphyletik, tetapi mungkin selanjutnya terjadi penggabungan gen betina dari Piliocolobus/Procolobus menjadi Colobus. Pada akhir Miosen, colobine menginvasi Eurasia dan memecah menjadi beberapa garis keturunan. Di antara colobine Asia, Semnopithecus yang pertama kali terpisah, menunjukkan parafili lutung. Namun, aliran gen searah dari Semnopithecus menjadi Trachypithecus melalui penggabungan gen jantan dengan nuklir swamping mungkin telah terjadi hingga awal Pleistosen

Kesimpulan: Secara umum, studi kami menyajikan bahasan yang paling komprehensif sampai saat ini tentang evolusi colobine dan menekankan bahwa analisis berbagai penanda molekuler, misalnya unsur-unsur bergerak dan data sekuens dari loci ganda, sangalah penting untuk lebih memahami hubungan evolusioner dan untuk melacak peristiwa hibridisasi. Hasil kami juga menunjukkan bahwa pola-pola dispersal yang 
khas menurut jenis kelamin, didukung oleh organisasi sosial dari suatu jenis dapat berakibat pada skenario hibridisasi yang berbeda untuk jenis tersebut.

\subsection{Introduction}

With more than 50 species and due to some ecological adaptations, such as a ruminant-like chambered stomach to digest food rich in fiber, the Old World monkey subfamily Colobinae represents a diverse and enigmatic group of primates (Groves 2001; Oates and Davies 1994). Colobines are predominantly arboreal and occur in forest and woodland habitats. They have experienced two major radiations, one in Africa with the genera Procolobus, Piliocolobus and Colobus, and a second in South and Southeast Asia comprising the langur genera Semnopithecus, Trachypithecus and Presbytis, and the odd-nosed monkey genera Rhinopithecus, Pygathrix, Nasalis and Simias (Groves 2001). However, their phylogenetic relationships are disputed (Groves 1989; Jablonski 1998; Jablonski et al. 1999; Stewart and Disotell 1998; Zhang and Ryder 1999), and recent molecular studies detected substantial gene tree discordance (Osterholz et al. 2008; Sterner et al. 2006; Ting et al. 2008).

Traditionally, African and Asian genera are believed to form reciprocally monophyletic groups (Groves 2001; Napier and Napier 1967; Oates et al. 1994; Szalay and Delson 1979), though paraphyly has also been proposed (Groves 1989; Jablonski 1998; Jablonski et al. 1999). Molecular investigations clearly confirm a common origin of Asian colobines and the odd-nosed monkey group (Osterholz et al. 2008; Sterner et al. 2006; Ting et al. 2008), but evidence for monophyly of the langur group as well as for African colobines is still lacking. Moreover, nuclear and mitochondrial data indicate conflicting relationships among langur genera, and between langurs and the odd-nosed monkeys (Osterholz et al. 2008; Sterner et al. 2006; Ting et al. 2008). While nuclear data consistently link Semnopithecus and Trachypithecus to the exclusion of all other Asian colobines (Osterholz et al. 2008; Ting et al. 2008), mitochondrial data either do not resolve 
these relationships (Osterholz et al. 2008) or suggest a clade consisting of Presbytis and Trachypithecus (Sterner et al. 2006).

Incongruent phylogenetic relationships among genes, like those detected among colobines are common in phylogenetic studies and could be explained by homoplasy, insufficient data, nucleotide composition, differential lineage sorting, or hybridization (Avise 2004; Barton 2001; Funk and Omland 2003; Koblmüller et al. 2007; McCracken and Sorenson 2005; Nichols 2001; Philippe and Laurent 1998; Pollard et al. 2006; Seehausen 2004). To ascertain which of these possibilities are responsible for the incongruence, information from various independent molecular loci can be helpful (Petit and Excoffier 2009). To date, only mitochondrial and X chromosomal data as well as presence/absence information of mobile elements, all based on an incomplete taxon sampling, are available for comparative phylogenetic studies in colobines (Osterholz et al. 2008; Sterner et al. 2006; Ting et al. 2008; Xing et al. 2005). Among all marker systems, mobile element insertions are a promising tool to uncover phylogenetic relationships among colobine genera. Compared to sole sequence data, mobile elements such as Short Interspersed Elements (SINEs) and Long Interspersed Elements (LINEs) exhibit advantages which make them ideal markers for phylogenetic reconstructions (for review see (Batzer and Deininger 1991; Okada 1991; Ray et al. 2006; Salem et al. 2005; Schmitz et al. 2005; Shedlock and Okada 2000; Van de Lagemaat et al. 2005)). Accordingly, mobile elements are successfully applied in numerous primate phylogenetic studies (Herke et al. 2007; Li et al. 2009; Osterholz et al. 2008, 2009; Ray et al. 2005; Roos et al. 2004; Salem et al. 2003; Schmitz et al. 2001; Schmitz et al. 2005; Xing et al. 2007a; Xing et al. 2007b).

In our study, we examined the presence/absence pattern of mobile elements and compared the inferred phylogeny with those derived from mitochondrial and nuclear sequence data (in total $\sim 30,000$ bp per genus). We extended available $X$ chromosomal and mitochondrial genome data, and sequenced de novo five autosomal loci that map to different human chromosomes, and six $\mathrm{Y}$ chromosomal loci from all ten colobine genera. By combining results from different marker systems, we provide detailed in- 
sights into the evolutionary and biogeographic history of colobine monkeys, and show that different hybridization mechanisms might have been involved during the colobine radiation.

\subsection{Methods}

\subsubsection{Sample collection and DNA extraction}

Blood, tissue or fecal samples from representatives of all ten colobine genera (Colobus, Piliocolobus, Procolobus, Presbytis, Trachypithecus, Semnopithecus, Rhinopithecus, Pygathrix, Nasalis, Simias) and several non-colobine taxa (Macaca, Papio, Theropithecus, Chlorocebus, Pongo, Pan) were obtained from specimens kept in zoos or breeding facilities, or collected in the field (Table 2.1). Sample collection was conducted according to relevant German and international guidelines, including countries where we collected samples. Fecal samples were collected in a non-invasive way without disturbing, threatening or harming the animals. Blood samples were taken by veterinarians for diagnostic reasons to check the health status of the respective individuals, and tissue samples were obtained only from deceased specimens. Total genomic DNA was extracted with the DNeasy Blood \& Tissue or QIAamp DNA Stool Mini kits from Qiagen following standard procedures.

\subsubsection{Analysis of mobile elements}

Due to their high copy number ( one million) and relatively small size ( $\sim 300 \mathrm{bp})$, the primate specific Alu elements were selected as molecular-cladistic markers. The presence or absence of mobile elements in different colobines at specific loci was tested via PCR using primers occupying the flanking region of the insertion site. Details on analyzed loci, primers and presence/absence pattern of mobile elements in studied species are listed in Additional File 1. For most loci, sequencing was neglected, but in relevant cases the insertion orthology was confirmed by sequencing, and direct repeats flanking the insertion as well as the original target site prior to transposition were traced. 
Table 2.1: Origin and sample type of studied species

\begin{tabular}{|l|l|l|}
\hline species & origin & $\begin{array}{l}\text { sample } \\
\text { type }\end{array}$ \\
\hline $\begin{array}{l}\text { Colobus guereza } \\
\text { Piliocolobus badius }\end{array}$ & Cologne zoo, Germany & tissue \\
\hline Procolobus verus & Taï National Park, Ivory Coast & tissue \\
\hline $\begin{array}{l}\text { Semnopithecus entellus } \\
\text { Trachypithecus obscurus }\end{array}$ & Dresden zoo, Germany & tissue \\
\hline Presbytis melalophos & Howletts Wild Animal Park, Great Britain & blood \\
\hline Pygathrix nemaeus & Cologne zoo, Germany & tissue \\
\hline Rhinopithecus avunculus & Endangered Primate Rescue Center, Viet- & tissue \\
\hline Nasalis larvatus & nam \\
\hline Simias concolor & Wilhelma Stuttgart, Germany & blood \\
\hline Macaca sylvanus & Siberut Conservation Programme, Indo- & feces \\
\hline Papio hamadryas & nesia & blood \\
\hline Theropithecus gelada & Munich zoo, Germany & Duisburg zoo, Germany \\
\hline Chlorocebus aethiops & Paul-Ehrlich-Institute, Germany & blood \\
\hline Pongo abelii & Nuremberg zoo, Germany & blood \\
\hline Pan troglodytes & Munich zoo, Germany & blood \\
\hline
\end{tabular}

In our study, we included published markers (Herke et al. 2007; Osterholz et al. 2008; Xing et al. 2005), which were further examined in previously untested genera, and newly detected integration loci (Additional File 1). Therefore, we performed subtractive hybridizations following described methods (Osterholz et al. 2008). To avoid biased hybridization results, various species combinations were used as tracer and driver (hybridization 1: tracer Nasalis/Pygathrix, driver Presbytis; hybridization 2: tracer Nasalis/Pygathrix, driver Semnopithecus; hybridization 3: tracer Trachypithecus/Presbytis, driver Pygathrix; hybridization 4: tracer Presbytis, driver Semnopithecus; hybridization 5: tracer Piliocolobus/Colobus, driver Pygathrix). Besides Alu insertions, a LINE present in Piliocolobus and Procolobus in the studied Xq13.3 fragment was additionally applied as marker (Additional File 1). 
Phylogenetic reconstructions using the MP algorithm were conducted in PAUP v4.0b10 (Swofford 2003). Presence of an integration was coded as 1 , its absence as 0 , and missing data as '?'. Internal node support was obtained via a heuristic search with 10,000 bootstrap replications. To evaluate the reliability of the depicted relationships among colobines, various alternative tree topologies were assessed with the KishinoHasegawa test (Kishino and Hasegawa 1989) with full optimization and 1,000 bootstrap replications in PAUP.

\subsubsection{Amplification and sequencing of nuclear loci}

Inter-exonic intron and exonic sequences were generated for six single-copy genes of the $\mathrm{Y}$ chromosome, five autosomal loci, and a fragment of the $\mathrm{X}$ chromosomal $\mathrm{Xq13.3}$ region. With exception of the SRY gene (sex-reversal, $Y$ chromosome), all other $Y$ chromosomal loci (DBY5: Dead Box, intron 5; SMCY7: SMC mouse homologue, intron 7; SMCY11: SMC mouse homologue, intron 11; UTY18: ubiquitous TPR motif, intron 18; ZFYLI: Zinc finger, last intron) have homologues on the $X$ chromosome ( $X$ degenerate). As autosomal loci, we selected intron 11 of the von Willebrand Factor ( $v W F 11)$, located on human chromosome 12, intron 3 of the serum albumin gene ( $A L B 3$, human chromosome 4), intron 3 of the interstitial retinol-binding protein (IRBP3, human chromosome 10), intron 1 of the transition protein 2 (TNP2, human chromosome 16) and intron 1 of the transthyretin gene (TTR1, human chromosome 18). SRY, DBY5, SMCY7, SMCY11, UTY18, vWF11 and a 4,300 bp fragment of the Xq13.3 region were amplified using primers and PCR conditions as described (Chaves et al. 1999; Hellborg and Ellegren 2003; Ting et al. 2008; Tosi et al. 2005; Whitfield et al. 1993) (Additional File 2). For the amplification of $Z F Y L I, A L B 3, I R B P 3, T N P 2$ and TTR1, new primers (Additional File 2) were designed on the basis of available primate sequences in GenBank. PCR conditions for the latter comprised a pre-denaturation step at $94^{\circ} \mathrm{C}$ for $2 \mathrm{~min}$, followed by 40 cycles each with denaturation at $94^{\circ} \mathrm{C}$ for $1 \mathrm{~min}$, annealing at varying temperatures (Additional File 2) for $1 \mathrm{~min}$, and extension at $72^{\circ} \mathrm{C}$ for $2 \mathrm{~min}$. At the end, a final extension step at $72^{\circ} \mathrm{C}$ for 5 min was added. The results of all PCR amplifications were checked on $1 \%$ agarose gels. PCR products were cleaned with the Qiagen PCR Purifica- 
tion kit and subsequently sequenced on an $A B I 3130 x \mid$ sequencer using the BigDye Terminator Cycle Sequencing kit. Alignments and sequences are available in TreeBASE (http://purl.org/phylo/ treebase/phylows/study/TB2:S11179) and GenBank, respectively (for GenBank accession numbers see Additional File 3).

\subsubsection{Amplification and sequencing of mitochondrial genomes}

To reduce the likelihood of amplifying nuclear pseudogenes (numts), complete mitochondrial genomes from four colobine genera (Rhinopithecus, Pygathrix, Nasalis, Procolobus) were generated following an approach in which two overlapping $\sim 10,000 \mathrm{bp}$ long fragments were amplified via long-range PCR (Raaum et al. 2005; Sterner et al. 2006). Due to degradation of DNA extracted from faeces, the mitochondrial genome of Simias was amplified via five overlapping fragments, each with a size of $\sim 5,000 \mathrm{bp}$. All long-range PCRs were performed with the SuperTaq Plus polymerase from Ambion following protocols of the supplier and primers as described (Raaum et al. 2005; Sterner et al. 2006). Long-range PCR amplicons were separated on $1 \%$ agarose gels, excised from the gel, purified with the Qiagen Gel Extraction kit and used as template for nested PCRs. PCR conditions for all nested PCR amplifications were identical and comprised a pre-denaturation step at $94^{\circ} \mathrm{C}$ for $2 \mathrm{~min}$, followed by 30 cycles each with denaturation at $94^{\circ} \mathrm{C}$ for $1 \mathrm{~min}$, annealing at $60^{\circ} \mathrm{C}$ for $1 \mathrm{~min}$, and extension at $72^{\circ} \mathrm{C}$ for $1.5 \mathrm{~min}$. At the end, a final extension step at $72^{\circ} \mathrm{C}$ for 5 min was added. Nested PCR products (900-1,200 bp in length) were cleaned with the Qiagen PCR Purification kit and sequenced on an $\mathrm{ABI} 3130 \mathrm{xl}$ sequencer. Sequences were assembled with Geneious v4.6.1 (Drummond et al. 2008). No inconsistent positions in overlapping regions were detected and all protein-coding genes were correctly translated. Annotation of mitochondrial genomes was conducted with the online program DOGMA (Wyman et al. 2004) and manually inspected. Alignment and sequences are available in TreeBASE (http://purl.org/phylo/treebase/phylows/ study/TB2:S11179) and GenBank, respectively (for GenBank accession numbers see Additional File 3). 


\subsubsection{Statistical analysis of sequence data}

For phylogenetic reconstructions, all datasets comprised 17 sequences including each one representative of the ten colobine genera (Colobus, Piliocolobus, Procolobus, Trachypithecus, Semnopithecus, Presbytis, Rhinopithecus, Pygathrix, Nasalis, Simias), four cercopithecine genera (Papio, Theropithecus, Macaca, Chlorocebus), and three hominoid genera (Homo, Pan, Pongo), which were used as outgroup taxa. To complete datasets, we partly implemented sequences from GenBank (Additional File 3). Alignments for individual loci were generated with MAFFT v6 (Katoh et al. 2005) and corrected by eye. In all alignments, poorly aligned positions and indels were removed with Gblocks v0.91b (Castresana 2000) using default settings. For the mitochondrial dataset, also the D-loop region was excluded (dataset mtDNA1) and a second alignment, generated in Mesquite v2.6 (Maddison and Maddison 2009), included solely proteincoding genes (dataset mtDNA2). For all datasets, uncorrected pairwise differences were estimated in PAUP. Nucleotide composition for all and only parsimonyinformative positions for the combined nuclear and both mitochondrial alignments was also estimated in PAUP. To test whether datasets can be combined, we performed partition homogeneity tests in PAUP with 10,000 replications.

Phylogenetic trees were constructed with MP and NJ algorithms as implemented in PAUP as well as with ML and Bayesian algorithms, using the programs GARLI v0.951 (Zwickl 2006) and MrBayes v3.1.2 (Huelsenbeck et al. 2001; Ronquist and Huelsenbeck 2003). For MP analyses, all characters were treated as unordered and equally weighted throughout. A heuristic search was performed with the maximum number of trees set to 100 . For NJ, ML and Bayesian reconstructions, the optimal nucleotide substitution models for each locus and concatenated datasets were chosen using AIC as implemented in MODELTEST v3.7 (Posada and Crandall 1998). Relative support of internal nodes was assessed by bootstrap analyses with 10,000 (MP, NJ) or 500 replications (ML). In GARLI, only the model specification settings were adjusted according to the respective concatenated dataset, while all other settings were left at their default value. ML majority-rule consensus trees were calculated in PAUP. 
For Bayesian reconstructions, the datasets were partitioned treating each locus separately and each with its own substitution model. The solely protein-coding alignment of the mitochondrial genome (mtDNA2) was partitioned into codon positions. We used four independent Markov Chain Monte Carlo (MCMC) runs with the default temperature of 0.1. Four repetitions were run for $10,000,000$ generations with tree and parameter sampling occurring every 100 generations. The first $25 \%$ of samples were discarded as burnin, leaving 75,001 trees per run. PPs for each split and a phylogram with mean branch lengths were calculated from the posterior density of trees.

To evaluate the reliability of obtained relationships among colobines, various alternative tree topologies were tested with the Shimodaira-Hasegawa test (Shimodaira and Hasegawa 1999) with full optimization and 1,000 bootstrap replications in PAUP.

\subsubsection{Divergence age estimation}

A Bayesian MCMC method, which employs a relaxed molecular clock approach (Drummond et al. 2006), as implemented in BEAST v1.4.8 (Drummond and Rambaut 2007), was used to estimate divergence times. Therefore, a relaxed lognormal model of lineage variation and a Yule prior for branching rates was assumed. Divergence times were calculated for each locus separately and for the combined nuclear dataset. The latter was partitioned treating each locus as distinct unit. The mitochondrial alignment comprising solely protein-coding genes (mtDNA2) was partitioned into codon positions and the substitution model, rate heterogeneity and base frequencies were unlinked across codon positions. Optimal nucleotide substitution models were chosen using AIC in MODELTEST.

As calibrations we used the fossil-based divergence between Homo and Pan, which has been dated at 6-7 mya (Brunet et al. 2005; Lebatard et al. 2008; Vignaud et al. 2002), the separation of Pongo from the Homo/Pan lineage 14 mya (Kelley 2002), the split 


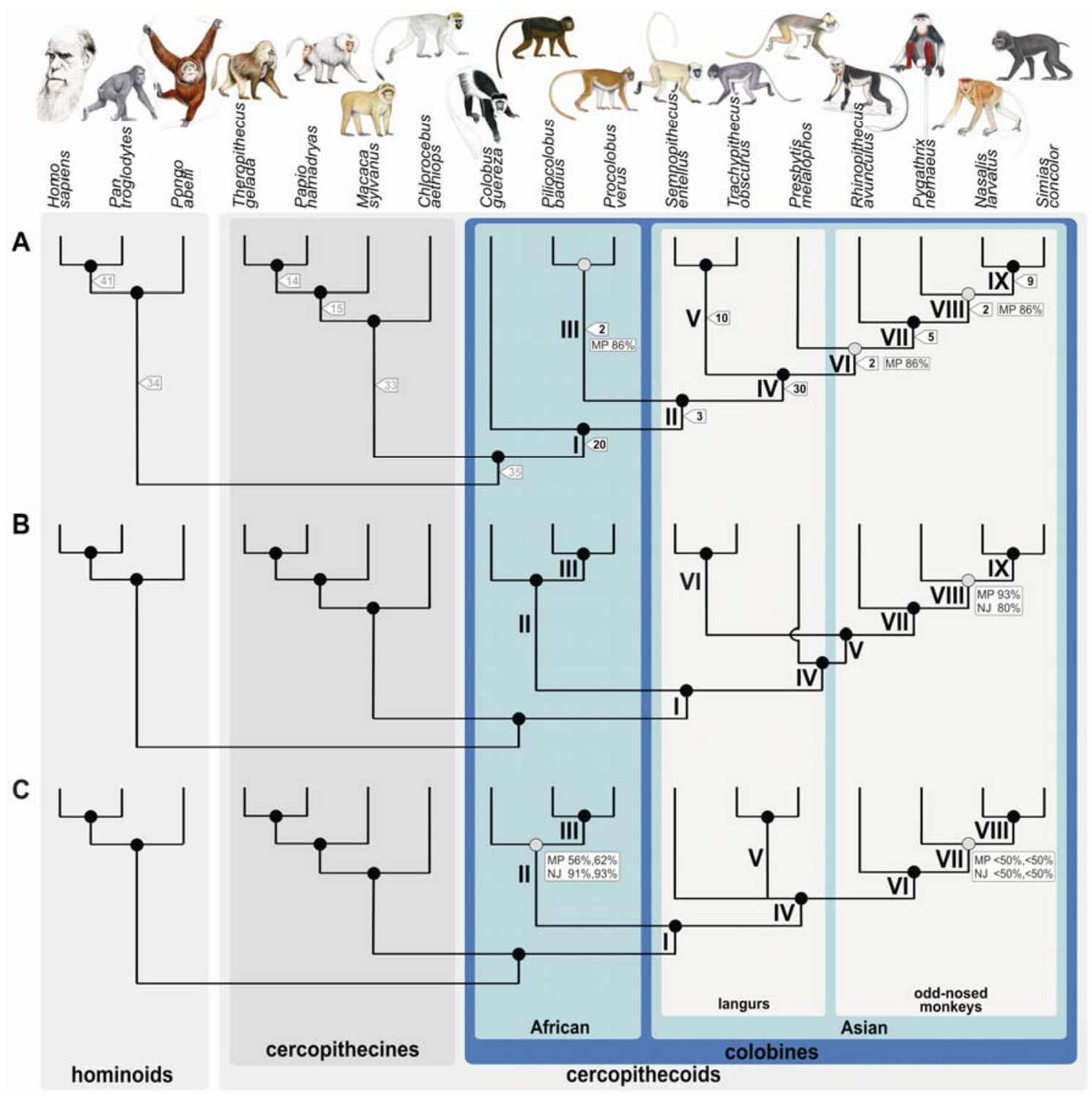

Figure 2.1: Phylogenetic relationships among colobine and outgroup genera as inferred from different datasets. Panels refer to insertions of mobile elements (A), combined nuclear sequence data (B), and mitochondrial genome data (C). Roman numbers are used as branch identifiers and are discussed in the text. In $A$, numbers in flags represent the number of available mobile elements (black: colobine markers, grey: non-colobine markers). In $B$ and $C$, all nodes are significantly supported by $M L$ and Bayesian reconstructions $(\geq 95 \%, 1.0)$. Black and grey dots on nodes indicate high $(\geq 95 \%)$ and lower $(<95 \%)$ branch support as obtained from MP (in A-C) and NJ (in B and C) reconstructions, respectively. Bootstrap values $<95 \%$ are presented at respective nodes. In C, first and second values refer to those obtained from reconstructions using datasets mtDNA1 and mtDNA2, respectively. 
between Theropithecus and Papio 4 mya (Delson 2000; Leakey 1993), and the divergence of hominoids and cercopithecoids 24 mya (Benefit and McCrossin 2002; Young and MacLatchy 2004; Zalmout et al.). Instead of hardbounded calibration points, we used the published dates as a normal distribution prior for the respective node.

For the Homo - Pan divergence, this translates into a normal distribution with a mean of 6.5 mya and a standard deviation (SD) of 0.5 mya, for the separation of Pongo from the Homo/Pan clade into a mean of 14.0 mya and a SD of 1.0 mya, for the Theropithecus - Papio split into a mean of 4.0 mya and a SD of 0.5 mya, and for the hominoid cercopithecoid divergence into a mean of 24 mya and a SD of 2 mya.

Since the estimation of phylogenetic relationships was not the main aim of this analysis, we used an apriori fixed tree topology as obtained from mobile elements (Figure 2.1 A) for the calculation from nuclear sequence data. Four replicates were run for $10,000,000$ generations with tree and parameter sampling occurring every 100 generations. The adequacy of a $10 \%$ burnin and convergence of all parameters were assessed by visual inspection of the trace of the parameters across generations using TRACER v1.4.1 (Rambaut and Drummond 2007). Subsequently, the sampling distributions were combined (25\% burnin) using the software LogCombiner v1.4.8 and a consensus chronogram with node height distribution was generated and visualized with TreeAnnotator v1.4.8 and FigTree v1.2.2 (Rambaut 2008).

\subsubsection{Inferring hybridization in the presence of incomplete lineage sorting}

Statistical support for putative hybridization scenarios was assessed with the method proposed by Kubatko (2009), in which statistical model selection techniques (e.g., AIC) are used to compare species trees that may or may not include hybridization scenarios. For our data, we hypothesized two possible hybridization events (for details see Results). The estimated gene trees used as input were those derived from single locus tree reconstructions (Additional File 4) and branch lengths as estimated in BEAST. To estimate evolutionary rates for individual loci, we followed the suggestion of Yang 

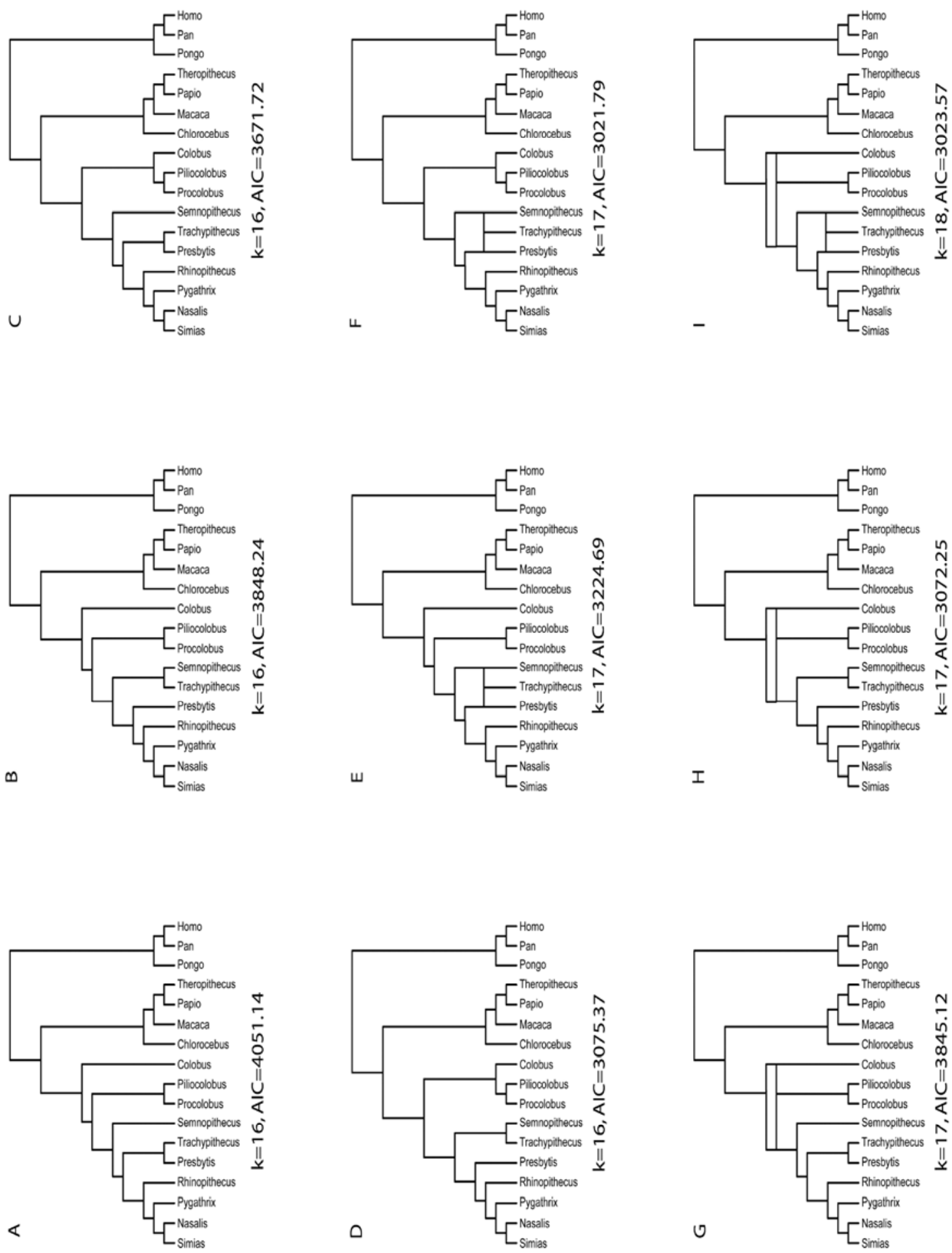

Figure 2.2: The nine alternative hybridization scenarios compared in the coalescent framework. Beneath each tree, the number of parameters in the model $(k)$ is given as well as the AIC. The lowest AIC values are observed for trees F and I, which indicate a similar fit fort hese scenarios. 
(2002) (see also (Kubatko et al. 2009)) and computed for each gene the average pairwise sequence divergence of each ingroup (colobine) sequence to the outgroup (noncolobine) taxa.

We then assigned to each locus a rate that was calculated by dividing the mean pairwise divergence for that locus by the median of the entire set of pairwise divergences. To convert gene tree branch lengths to coalescent units, we considered two effective population sizes, 50,000 and 100,000 , and used a generation time of 5 years. Since the results were identical in terms of the trees preferred, we show here the results only for effective population size 50,000. For haploid loci (mitochondrial genome, Y chromosomal loci), we additionally divided the rate by 2 (see (Kubatko et al. 2009)). We compared a total of nine species trees (four corresponding to no hybridization, four corresponding to single hybridization events, and one that included both hybridization scenarios, Figure 2.2). The AIC was computed for each tree using the STEM software (Kubatko et al. 2009). Models with AIC values within 2 of one another were regarded as providing similar fit to the data (Burnham and Anderson 2002).

\subsection{Results}

\subsubsection{Nuclear phylogeny}

Eighty-three mobile elements are phylogenetically informative for colobines (Figure 2.1 A, Additional File 1). Each of the following clades is strongly supported by at least five integrations: all colobines (clade I [A-I]), Asian colobines (A-IV), odd-nosed monkeys (A-VII), Trachypithecus and Semnopithecus (A-V), and Nasalis and Simias (A-IX). Three integrations were found in Piliocolobus and Procolobus and all Asian colobines (A-II), but not in Colobus. Two insertions suggested a sister grouping of Procolobus and Piliocolobus (A-III), Presbytis and the odd-nosed monkeys (A-VI), and a basal position of Rhinopithecus among the latter (A-VIII). Based on maximum-parsimony (MP) bootstrap analysis, most relationships were strongly supported ( $\geq 95 \%)$. Only the Pilio- 
colobus/Procolobus (A-III), Presbytis/odd-nosed monkey (A-VI), and Pygathrix/Nasalis/Simias (A-VIII) clades gained relatively weak bootstrap values (86\%). Based on alternative tree topology tests, different positions of the Piliocolobus/Procolobus clade and Presbytis among colobines were not rejected $(P>0.05)$, while relationships other than the most likely one were significantly rejected for all other taxa $(P<0.001, P<0.05)$.

Next, we performed phylogenetic analyses based on the concatenated nuclear sequence dataset, including five autosomal loci, six $\mathrm{Y}$ chromosomal loci and a fragment of the $X$ chromosomal Xq13.3 region. We combined all nuclear sequence data, because heuristic search methods for individual loci produced no conflicting relationships (Additional File 4), and partition homogeneity tests revealed no significant difference in their evolutionary history ( $Y$ chromosomal loci combined: $P=0.2939$; autosomal loci combined: $P=0.1543$; all nuclear loci combined: $P=0.3559)$. Nucleotide composition of studied species was similar. Phylogenetic reconstructions yielded identical and significantly supported branching patterns irrespectively of the applied algorithm (MP, neighbor-joining [NJ], maximum-likelihood [ML], Bayesian) (Figure 2.1 B). Only the Pygathrix/Nasalis/Simias (B-VIII) clade had lower support values (MP: 93\%, NJ: 80\%, but ML: 98\%, Bayesian posterior probabilities [PP]: 1.0). The resultant tree topology was mainly congruent with the mobile element-based phylogeny, but two cases of incongruence were obvious. First, in the nuclear sequence-based phylogeny, African (B-II) and Asian (B-IV) colobine genera formed reciprocally monophyletic clades and second, Presbytis represented a sister lineage to the other Asian genera (B-V). According to alternative tree topology tests, paraphyly of African colobines with Piliocolobus/Procolobus being closer related to Asian colobines than to Colobus as well as various alternative positions of Presbytis among Asian colobines were not rejected $(P>$ 0.05). However, affiliations of Presbytis to either Semnopithecus or Trachypithecus were rejected $(P<0.001)$.

Estimated divergence ages from the combined nuclear dataset (Table 2.2) and single loci (Additional File 5), both based on an a-priori fixed tree topology as obtained from 
mobile elements, differed slightly, most likely due to the general low variability in the studied loci. However, estimates were in the same range suggesting that loci evolve at similar evolutionary rates. According to our nuclear estimates, Colobus and Piliocolobus/Procolobus successively split off from Asian genera 10.93 million years ago (mya) and 10.73 mya, respectively (for 95\% highest posterior densities see Table 2.2). The latter two separated 6.92 mya. In Asia, an initial split occurred 8.12 mya and led to a clade consisting of Trachypithecus and Semnopithecus, and a group containing Presbytis and the odd-nosed monkeys. Among the latter, Presbytis diverged 7.96 mya and the odd-nosed monkeys began differentiating 6.43 mya. The most recent splits among Asian genera occurred between Trachypithecus and Semnopithecus (2.56 mya) and between Nasalis and Simias (1.06 mya).

\subsubsection{Mitochondrial phylogeny}

Mitochondrial and nuclear datasets were not combined, because the partition homogeneity test suggested that both track different evolutionary histories $(P=0.0002)$. Thus, mitochondrial sequence data were analyzed separately. For both alignments (mtDNA1, mtDNA2; for details about alignments see Materials and methods), we observed a major shift in nucleotide composition between colobine and non-colobine representatives. Both alignments produced identical and significantly supported branching patterns among genera (Figure $2.1 \mathrm{C}$ ). Only the Pygathrix/Nasalis/Simias (CVII) and African colobine (C-II) clades gained low MP (<50\%, <50\%, 56\%, 62\%) and NJ $(<50 \%,<50 \%, 91 \%, 93 \%)$ bootstrap values, but $\mathrm{ML}$ and Bayesian reconstructions provided strong support for both nodes $(96 \%, 100 \% ; 1.0,1.0)$. In principal, the tree topology was identical to those obtained from mobile elements and nuclear sequence data. However, as in the nuclear sequence tree, mitochondrial data suggested African (C-II) and Asian (C-IV) colobines as reciprocal monophyletic clades. Moreover, Asian colobines further diverged into a lineage leading to the odd-nosed monkeys (C-VI), a lineage comprising Trachypithecus and Presbytis (C-V), and finally a lineage with solely 
Semnopithecus, while the relationships among these three lineages remained unresolved.

According to alternative tree topology tests, paraphyly of African colobines with Piliocolobus/Procolobus being closer related to Asian colobines than to Colobus was rejected $(P<0.001)$. Among Asian colobines, relationships in which Trachypithecus and Presbytis do not form a monophyletic clade were also rejected $(P<0.001, P<0.05)$, as well as a close relationship of Trachypithecus and Semnopithecus $(P<0.01)$. In contrast, different positions of Semnopithecus among Asian colobines were similarly likely $(P>0.05)$.

Divergence age estimates from mitochondrial data were similar to nuclear estimates in case where identical branching patterns were obtained (Table 2.2). According to mitochondrial data, African and Asian colobine lineages were separated 10.90 mya. In Africa, Colobus represents the first split ( 8.47 mya), followed by the divergence of Piliocolobus and Procolobus (6.58 mya). The major Asian split leading to the three lineages Semnopithecus, Trachypithecus/Presbytis and the odd-nosed monkeys occured 8.91 mya.

Trachypithecus diverged from Presbytis 7.45 mya. The diversification of odd-nosed monkeys into genera started 6.91 mya and ended with the split between Nasalis and Simias 1.88 mya. 
Table 2.2: Estimation of divergence ages in mya (95\% highest posterior density)

\begin{tabular}{|c|c|c|}
\hline node & $\begin{array}{l}\text { nuclear } \\
\text { DNA }\end{array}$ & $\begin{array}{l}\text { mitochondrial } \\
\text { DNA }\end{array}$ \\
\hline cercopithecoids - hominoids & $24.39(22.44-26.47)$ & $23.73(21.88-25.94)$ \\
\hline Pongo-Homo/Pan & $13.89(12.80-14.95)$ & $13.58(12.51-14.64)$ \\
\hline Homo - Pan & $6.39(5.85-7.01)$ & $6.18(5.62-6.70)$ \\
\hline cercopithecines - colobines & $15.50(14.45-16.56)$ & $15.92(14.11-17.79)$ \\
\hline $\begin{array}{l}\text { Cholorocebus - other cercopitheci- } \\
\text { nes }\end{array}$ & $9.47(7.52-11.57)$ & $10.56(8.78-12.29)$ \\
\hline Macaca-Papio/Theropithecus & $6.59(5.12-8.27)$ & $8.55(6.82-10.03)$ \\
\hline Papio - Theropithecus & $3.80(3.20-4.38)$ & $3.97(3.39-4.46)$ \\
\hline Colobus - other colobines (A-I) & $10.93(9.60-12.31)$ & - \\
\hline $\begin{array}{l}\text { Piliocolobus/Procolobus - } \\
\text { Asian colobines (A-II) }\end{array}$ & $10.73(9.38-12.04)$ & - \\
\hline African - Asian colobines (C-I) & - & $10.90(9.34-12.44)$ \\
\hline $\begin{array}{l}\text { Colobus - Piliocolobus/Procolobus } \\
\text { (C-II) }\end{array}$ & - & $8.47(6.83-9.88)$ \\
\hline Piliocolobus - Procolobus (A-III, C-III) & $6.92(4.38-9.35)$ & $6.58(4.99-8.04)$ \\
\hline Asian colobines (A-IV, C-IV) & $8.12(7.14-9.16)$ & $8.91(7.43-10.23)$ \\
\hline $\begin{array}{l}\text { Trachypithecus - Semnopithecus (A- } \\
\text { V) }\end{array}$ & $2.56(1.25-4.22)$ & - \\
\hline $\begin{array}{l}\text { Presbytis - odd-nosed monkeys (A- } \\
\text { VI) }\end{array}$ & $7.96(6.93-8.95)$ & - \\
\hline Presbytis - Trachypithecus (C-V) & - & $7.45(5.88-8.86)$ \\
\hline odd-nosed monkeys (A-VII, C-VI) & $6.43(5.03-7.75)$ & $6.91(5.60-8.20)$ \\
\hline $\begin{array}{l}\text { Pygathrix - Nasalis/Simias (A-VIII, C- } \\
\text { VII) }\end{array}$ & $5.66(4.22-7.01)$ & $6.23(5.11-7.38)$ \\
\hline Nasalis - Simias (A-IX, C-VIII) & $1.06(0.44-1.81)$ & $1.88(1.21-2.45)$ \\
\hline
\end{tabular}




\subsubsection{Inferring hybridization in the presence of incomplete lineage sorting}

To assess the possible reasons for the incongruence between the nuclear and mitochondrial trees, we applied the method proposed by Kubatko (2009). The method assumes that incomplete lineage sorting (ILS) explains observed gene tree incongruence to some extent, and seeks to determine whether all variation in observed gene trees can be explained by ILS alone, as modeled by the coalescent process, or whether hybridization helps to explain significantly more the observed variation. Then, the Akaike information criterions (AIC) in each model (may or may not include hybridization scenarios) were compared to determine the best-fit model. For our data, two possible hybridization events were hypothesized. The first involved Trachypithecus, with parental taxa Semnopithecus and Presbytis, while the second involved the clade containing Piliocolobus and Procolobus, Colobus and the ancestor of Asian colobines.

By comparing the results from models with or without the hybridization events, the best-fit model (AIC $=3021.79$, Figure 2.2) was a tree in which Trachypithecus is the result of hybridization between Presbytis and Semnopithecus. The second best-fit model ( $\mathrm{AIC}=3023.57$, Figure $2.2 \mathrm{I})$ comprised the tree that includes both tested hybridization events. AIC values for all seven other models were considerably higher (3072.25 - 4051.14). Since AIC values for the scenarios presented in Figure $2.2 \mathrm{~F}$ and Figure 2.2 I were the lowest and were within 2 of one another, both were considered plausible explanations for the observed gene tree discordances (Burnham and Anderson 2002).

It is worth pointing out that the model used here to compute the AIC assumes that ILS is a possible source of gene trees incongruence. Since the two best-fit models include at least one hybridization event, it is clear that ILS alone does not adequately describe the extent of incongruence in the observed gene trees. 


\subsection{Discussion}

By combining presence/absence analysis of mobile elements with autosomal, $\mathrm{X}$ chromosomal, Y chromosomal and mitochondrial sequence data, the present study provides comprehensive insights into the evolutionary history of colobines. Most relationships are resolved and strongly supported by mobile elements and sequence data. Moreover, relationships and estimated divergence ages as obtained from different datasets are mainly congruent and in agreement with earlier studies (Goodman et al. 1998; Karanth et al. 2008; Osterholz et al. 2008; Raaum et al. 2005; Sterner et al. 2006; Ting 2008; Ting et al. 2008; Xing et al. 2005). Our study, however, also reveals significant discrepancies among gene trees. First, mitochondrial and nuclear sequence data suggest a monophyletic African colobine clade, while mobile elements provide evidence for a closer connection of the Piliocolobus/Procolobus clade to Asian genera than to Colobus. Second, mobile elements indicate close relationships between Semnopithecus and Trachypithecus, and between Presbytis and the odd-nosed monkeys. Nuclear sequence data support the former clade, but suggest Presbytis as basal among Asian colobines. In contrast, in the mitochondrial phylogeny, Presbytis and Trachypithecus are displayed as sister lineages, while the position of Semnopithecus remains ambiguous.

\subsubsection{Possible explanations for gene tree discordance}

Inadequate data, homoplasy, nucleotide composition, ILS or hybridization could be potential explanations for the observed differences (Avise 2004; Barton 2001; Funk and Omland 2003; Koblmüller et al. 2007; McCracken and Sorenson 2005; Nichols 2001; Philippe and Laurent 1998; Pollard et al. 2006; Seehausen 2004). For the mitochondrial dataset, at least for the African and Presbytis/Trachypithecus clades, incorrect branching patterns due to inadequate data or homoplasy are unlikely, since sufficient phylogenetic resolution with long internal branches is obtained. Likewise, a shift in nucleotide composition and differential sorting of ancestral mitochondrial lineages is implausible. Since the major shift in nucleotide composition was detected between 
colobines and non-colobines, it cannot be responsible for gene tree discordances among colobines. If the African and Presbytis/Trachypithecus clades are indeed the result of incomplete sorting of mitochondrial lineages, the mitochondrial divergence between respective genera should predate the nuclear splitting times, which is not the case (African colobines: 10.93 mya nuclear vs. 8.47 mya mitochondrial; Presbytis Trachypithecus: 8.12 mya nuclear vs. 7.45 mya mitochondrial). However, the unresolved position of Semnopithecus among Asian colobines might have been affected by one or several of the above mentioned factors, or alternatively, might be the result of a true radiation-like divergence of lineages. For nuclear data, these factors are unlikely explanations as well for the branching of Trachypithecus and Semnopithecus, because ten independent insertions and sequence data from 12 nuclear loci clearly confirm their close relationship. More challenging are explanations for the discordant positions of Presbytis and the African genera among colobines in phylogenies revealed by mobile elements and nuclear sequence data. Mixed genomes due to differentially selected genes cannot be excluded, but interestingly, both mobile elements and nuclear sequence data (as revealed from single locus analysis) show no conflicting phylogenies themselves. Most prominent, however, the mobile element-based phylogeny is not rejected by nuclear sequence data, indicating that insufficient informative sites, as also suggested by the low resolution of phylogenetic relationships in single-locus analysis, in the latter dataset might display incorrect relationships. For the integration of mobile elements, homoplasy is typically regarded as minimal (Okada 1991; Ray et al. 2006; Schmitz et al. 2005), but ILS has been reported (Li et al. 2009; Xing et al. 2007a). Only two and three integrations support the branching of Presbytis with odd-nosed monkeys and the paraphyly of African colobines, and alternative relationships cannot be rejected statistically. However, no inconsistent elements were detected and subtractive hybridizations specifically set up to screen for African colobine and Trachypithecus/Presbytis monophyly markers revealed no equivalent insertions. Accordingly, ILS seems to be an unreasonable explanation for our findings. Since the mobile elementbased phylogeny is not rejected by nuclear sequence data and due to their reliability as molecular-cladistic markers, the phylogeny suggested by mobile elements is assumed 
to reflect the true nuclear phylogeny of colobines, although we explicitly note that mosaic genomes cannot be excluded.

Because all above-mentioned factors provide no sufficient explanation for the herein detected discordances between mitochondrial and nuclear phylogenies, we favor ancestral hybridization as the main reason for the discordant pattern. Furthermore, comparisons of models with and without hybridization in a model selection framework strongly support hybridization in the presence of ILS over models of ILS alone. In other words, even after ILS was taken into account as a factor in the observed incongruence among gene trees, we still found support for hybridization in the evolutionary history of these taxa. This refers at least to Asian colobines, but hybridization among African colobines cannot be excluded either by the method we applied here.

\subsubsection{Hybridization hypothesis}

Although bidirectional hybridization, which would be indicated by mixed genomes, cannot be excluded with our data, a female introgression event is hypothesized for African colobines. The direction of gene flow remains obscure due to the rapid diversification of the colobine ancestor in Africa, but female introgression from Piliocolobus/Procolobus into Colobus is indicated and gains further support by some biological data (Groves 2001; Newton and Dunbar 1994). In contrast to Colobus, females in Piliocolobus and Procolobus tend to leave their natal groups, which was most likely also the case in their ancestor (Newton and Dunbar 1994), and Colobus males are on average larger than Piliocolobus and Procolobus males (Oates et al. 1994), thus increasing the chance of hybridization between Colobus males and Piliocolobus/Procolobus females. Moreover, hybridization between both ancestral lineages is in principal possible, because (at least nowadays) they occur in sympatry over wide ranges of their distribution (Groves 2001; Oates et al. 1994). Accordingly, after the successive separation of Colobus and Piliocolobus/Procolobus from the Asian colobine ancestor, Piliocolobus/Procolobus females might have entered Colobus populations and hybridized with their males. Backcrossing of hybrid females with resident Colobus males might has led to the fixation of the Piliocolobus/Procolobus mitochondrial lineage in the hy- 
brid population, while the original nuclear genome of Colobus increased again in every generation.

For Asian langurs, we propose male introgression from Semnopithecus into Trachypithecus followed by nuclear swamping. Both genera are similar in their morphology and general appearance (Brandon-Jones 1984; Groves 2001; Strasser and Delson 1987), but males in Semnopithecus are larger than in Trachypithecus (Oates et al. 1994). Moreover, hybridization events due to (at least nowadays) partially overlapping ranges are generally possible (Groves 2001; Oates 1994). Accordingly, after an initial separation, Semnopithecus males, which leave their natal group like most other primate males (Newton and Dunbar 1994; Pusey and Packer 1987), might have invaded Trachypithecus populations and hybridized successfully with the resident females. By backcrossing with further invading Semnopithecus males over a longer period, the Trachypithecus population might have accumulated nuclear material of Semnopithecus (nuclear swamping), while the mitochondrial genome remained Trachypithecus-like.

\subsubsection{Biogeographic implications}

By combining the available information, we develop the following extended dispersal scenario for colobines (Figure 2.3). The origin of the subfamily is most likely in Africa, which is in agreement with earlier suggestions (Delson 1994; Stewart and Disotell 1998). On the African continent, Colobus split off first from the main stem 10.93 mya, followed shortly afterwards by the progenitor of Piliocolobus and Procolobus. After this initial separation, hybridization between both lineages might have lasted until finally both mitochondrial lineages diverged ( 8.47 mya). Presumably, respective splitting and hybridization events took place in western Africa, because all three genera occur there in sympatry (Groves 2001; Oates 1994), and the most ancient splits among Piliocolobus and Colobus species are also found there (Ting 2008). The Asian colobine ancestor most likely invaded Eurasia via an emerging land bridge connecting Africa and the Arabian Peninsula in the late Miocene (Stewart and Disotell 1998; Whybrow 1992). 


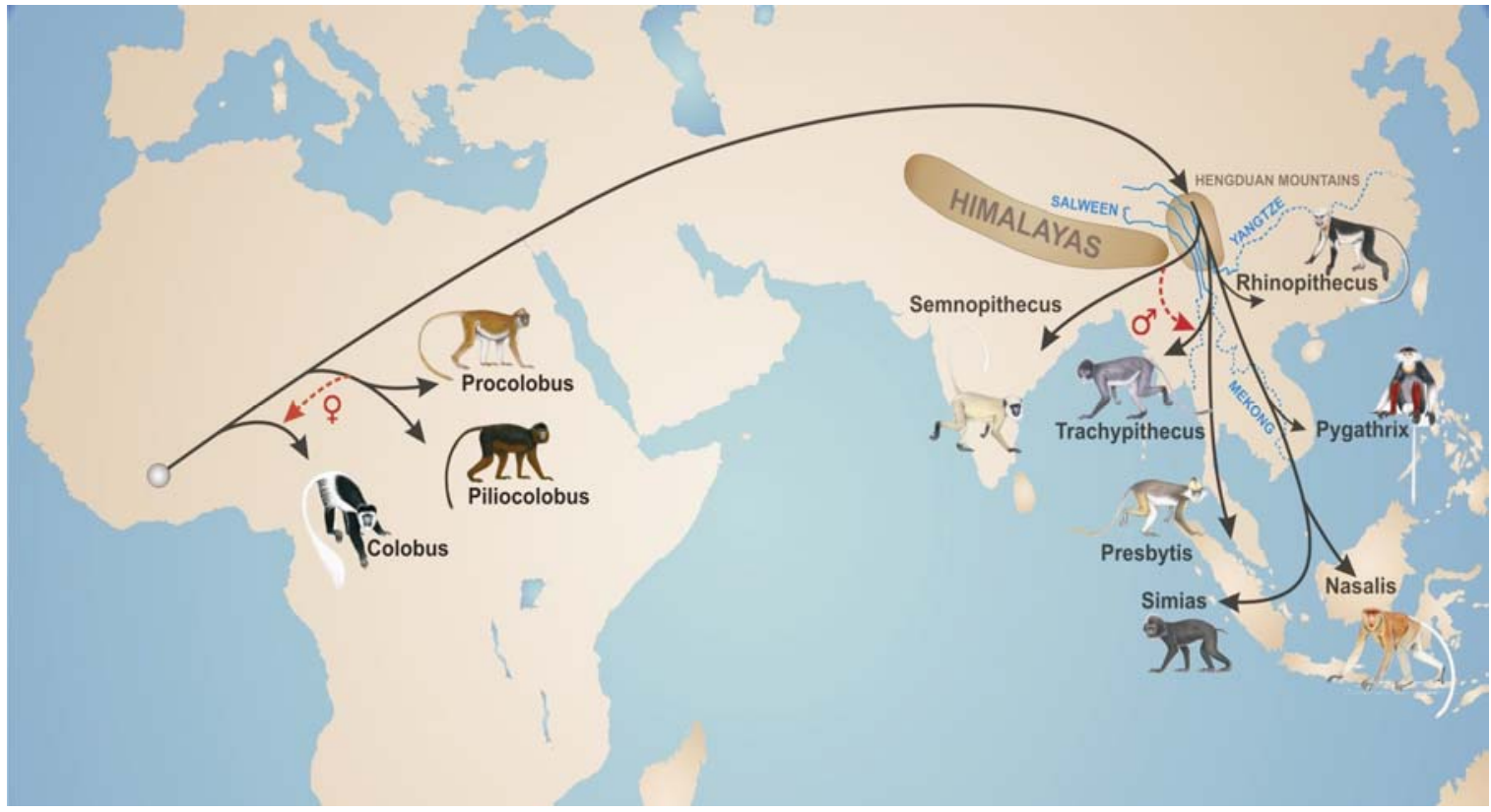

Figure 2.3: Dispersal scenario for colobine monkeys. Colobines most likely originated in western Africa. After the successive split of Colobus ( 10.9 mya) and a progenitor of Piliocolobus/Procolobus ( 10.7 mya) from the ancestor of Asian colobines, gene flow between both African lineages via female introgression from the Piliocolobus/Procolobus progenitor into Colobus occurred until $\sim 8.5$ mya (displayed by red-dashed arrow). During the late Miocene, colobines invaded eastern Asia most likely via a route north of the Himalayas. After their arrival at the Hengduan Mountains, Asian colobines diversified into a lineage comprising a progenitor of the odd-nosed monkeys and Trachypithecus/Presbytis, and of Semnopithecus, which later colonized the Indian subcontinent. Shortly afterwards, Trachypithecus/Presbytis split off from odd-nosed monkeys, and migrated to southern mainland Asia, before finally both genera diverged from each other. In the region of today's Burma, Bangladesh and India, Semnopithecus and Trachypithecus came into secondary contact and hybridized until $\sim 2.6$ mya (displayed by reddashed arrow). In the latest Miocene, odd-nosed monkeys migrated from China to the south and expanded their range into Indochina and Sundaland. Nasalis and Simias finally separated from each other 1.1-1.9 mya.

Whether a route into eastern Asia north or south of the Himalayas was chosen is a matter of speculation, but north of the Himalayas, on the Tibetan plateau, colobine fossils from the late Miocene were found, which is not the case south of the Himalayas (Delson 1994). Although not confirmed, the Hengduan Mountains in the border region of today's Burma, India and China might have been a possible diversification hotspot (Jablonski 1998; Peng et al. 1993; Thinh et al. 2010a). In the region, all the larger Southeast Asian rivers (Mekong, Salween, Yangtze) rise, which are all well-known as 
barriers for arboreal primates (Meijaard and Groves 2006) and are all known to exist since at least the early Miocene (Hallet and Molnar 2001). Semnopithecus might have diverged as first lineage and invaded the Indian subcontinent. Subsequently, the progenitor of Presbytis and Trachypithecus separated from the odd-nosed monkey ancestor and migrated into southern mainland Asia. Afterwards, Presbytis diverged from Trachypithecus and entered first the Malaysian peninsular and later on Sundaland during periods of lowered sea levels (Miller et al. 2005). Trachypithecus and Semnopithecus came into secondary contact and might have hybridized until the earliest Pleistocene. A potential contact zone could be the region of today's Bangladesh, Burma and the northeast of India, which is suggested as hybridization area for several primate species (Chakraborty et al. 2007; Karanth et al. 2008; Osterholz et al. 2008). On the Asian mainland, odd-nosed monkeys successively migrated from China to the south and expanded their range into Indochina and Sundaland in the latest Miocene. The migration into Sundaland was probably via land bridges connecting the mainland with Sundaland islands during periods of lowered sea levels (Miller et al. 2005). Finally, Nasalis on Borneo and Simias on the Mentawai islands west of Sumatra diverged in the Pleistocene. Due to the dating discrepancy (mitochondrial data: 1.88 mya, nuclear data: 1.06 mya), further gene flow between both genera after the initial separation cannot be excluded, especially considering that migration was repeatedly possible via land bridge connections during the Pleistocene (Miller et al. 2005).

\subsection{Conclusion}

Our study gives new and most comprehensive insights into the evolutionary history of colobine monkeys, and suggests hybridization among ancestral lineages as the most likely cause for the observed phylogenetic incongruences. Only the combination of maternally, paternally and bi-parentally inherited markers as well as the combination of sequence data with presence/absence patterns of mobile elements proved to be an adequate and reliable phylogenetic approach, particularly in revealing hybridization events. However, data from additional nuclear loci and a broader taxonomic sampling is required to fully understand hybridization mechanisms in colobines. 
Hybridization among taxa is traditionally recognized as a factor leading to limited diversification, reproductive isolation and lowered fitness (Darwin 1859; Mayr 1963), whereas our and earlier studies clearly indicate that hybridization played a prominent role in diversification and speciation of primates (for review see (Arnold and Meyer 2006; Zinner et al. 2011)). Hybridization events are genetically confirmed within all major primate lineages, mainly among species (Chakraborty et al. 2007; Cortes-Ortiz et al. 2007; Merker et al. 2009; Rumpler et al. 2008; Thalmann et al. 2007; Zinner et al. 2009b) but also between genera (Karanth et al. 2008; Osterholz et al. 2008; Zinner et al. 2009a). Even for the human lineage, hybridization has been suggested as an important evolutionary mechanism (Green et al.; Pääbo 2003; Patterson et al. 2006).

Since male dispersal and female philopatry predominates in primates (Pusey and Packer 1987), male introgression, and if intensive backcrossing of hybrids with more invading males occurs, followed by nuclear swamping would be the most likely hybridization scenario. In fact, the hybridization among Asian langur genera is most likely the result of such an event. However, as proposed for African colobines, alternative mechanisms (e.g. female introgression) could also occur, promoted by a respective social organization, where female migration predominates.

\subsection{Acknowledgements}

We thank the zoos in Cologne, Dresden, Duisburg, Howletts, Munich, Nuremberg, Stuttgart and Wuppertal, and Roland Plesker and Werner Schempp for providing samples. We are also grateful to our colleagues at Bogor Agricultural University (IPB) and the Indonesian Institute for Science (LIPI) as well as the Ivorian authorities, the Ministry of the Environment and Forests, the Ministry of Research, the directorship of Taï National Park and the Swiss Research Centre for providing the necessary field research permits and documents. No international and national rules and regulations have been violated during sampling and shipping. We thank Vanessa Roden, Laura Zidek, Linn Groeneveld, Daniel Stahl and two anonymous reviewers for valuable comments on an earlier version of the manuscript and statistical help. This work was supported by the 
German Primate Center and the Biodiversitäts-Pakt of the Wissenschaftsgemeinschaft Gottfried-Wilhelm Leibniz to CR, DZ and LW, and by grants from the National Institutes of Health to MAB (RO1 GM59290) and JX (K99 HG005846). 


\section{Chapter 3 Mitochondrial phylogeny of leaf monkeys (genus Presbytis, Eschscholtz, 1821) with implications for taxonomy and conservation}

Molecular Phylogenetics and Evolution 59 (2011) 311-319

Dirk Meyer a,b,*, Ir. Dones Rinaldi ${ }^{c}$, Hatta Ramlee ${ }^{\mathrm{d}}$, Dyah Perwitasari-Farajallah e,f J. Keith Hodges ${ }^{\mathrm{a}}$, Christian Roos ${ }^{\mathrm{g}}$

a Unit of Reproductive Biology, German Primate Center, Kellnerweg 4, D-37077 Göttingen, Germany ${ }^{b}$ Göttingen Center for Biodiversity and Ecology, Untere Karspüle 2, D-37073 Göttingen, Germany

'Department of Forest Resources Conservation and Ecotourism, Bogor Agricultural University, Jalan Dermaga, Bogor, Indonesia

${ }^{\mathrm{d} S}$ School of Archaeology and Anthropology, Faculty of Arts, The Australian National University, ACT 0200 Canberra, Australia

e Primate Research Center, Bogor Agricultural University, Jalan Lodaya II/5, Bogor 16151, Indonesia

'Department of Biology, Faculty of Mathematics and Natural Sciences, Bogor Agricultural University, Indonesia

${ }^{8}$ Gene Bank of Primates and Primate Genetics Laboratory, German Primate Center, Kellnerweg 4, D-37077 Göttingen, Germany

A R T I C L E I N F O

\section{Article history:}

Received 28 June 2010

Revised 12 February 2011

Accepted 14 February 2011

Available online 17 February 2011

\section{Keywords:}

Colobinae

Cytochrome b

D-loop

Sundaland

Asia

Taxonomy

Presbytis

Indonesia

Conservation

\section{A B S T R A C T}

The langurs of the genus Presbytis inhabit tropical rainforests of Sundaland, and with more than 50 color variants grouped in up to eleven species, Presbytis is one of the most diverse Old World monkey genera. The number of taxa and their phylogenetic relationships however remain controversial. To address these issues, we analyzed a $1.8 \mathrm{~kb}$ long fragment of the mitochondrial genome, including the cytochrome gene, the hypervariable region I of the D-loop and the intermediate tRNAs, from individuals representing nine species. Based on our data, we obtained various well-supported terminal clades, which refer mainly to described taxa. Relationships among these clades are not fully resolved, suggesting at least two radiations in the evolutionary history of the genus. According to divergence age estimates, radiations occurred in the late Miocene and the early to middle Pleistocene. Our findings support the revision of the current classification of the genus Presbytis and enable us to discuss implications for conservation. However, further studies including nuclear sequence data are necessary to completely understand the evolutionary history of the genus, and to address possible hybridization events among taxa.

Crown Copyright $₫ 2011$ Published by Elsevier Inc. All rights reserved. 


\subsection{Abstract}

The langurs of the genus Presbytis inhabit tropical rainforests of Sundaland, and with more than 50 color variants grouped in up to eleven species, Presbytis is one of the most diverse Old World monkey genera. The number of taxa and their phylogenetic relationships however remain controversial. To address these issues, we analyzed a 1.8 $\mathrm{kb}$ long fragment of the mitochondrial genome, including the cytochrome $\mathrm{b}$ gene, the hypervariable region I of the D-loop and the intermediate tRNAs, from individuals representing nine species. Based on our data, we obtained various well-supported terminal clades, which refer mainly to described taxa. Relationships among these clades are not fully resolved, suggesting at least two radiations in the evolutionary history of the genus. According to divergence age estimates, radiations occurred in the late Miocene and the early to middle Pleistocene. Our findings support the revision of the current classification of the genus Presbytis and enable us to discuss implications for conservation. However, further studies including nuclear sequence data are necessary to completely understand the evolutionary history of the genus, and to address possible hybridization events among taxa.

\subsubsection{Ringkasan}

Lutung dari marga Presbytis menghuni hutan hujan tropis wilayah Sunda, yang memiliki lebih dari 50 variasi warna yang dikelompokkan ke dalam 11 jenis. Presbytis merupakan salah satu marga monyet Dunia Lama yang paling beragam. Walaupun demikian jumlah taksa dan kekerabatan filogenetiknya masih kontroversial. Untuk membahas isu ini, kami menganalisis satu fragmen genom mitokondria, meliputi gen $b$ cytochrome, region hypervariabel I dari D-loop dan tRNA intermediate, dari individuindividu yang mewakili sembilan jenis. Berdasarkan data kami, kami memperoleh berbagai clade terminal yang didukung dengan baik, yang terutama mengacu pada taksa yang telah dideskripsikan. Hubungan antara clade ini tidak sepenuhnya terjelaskan, menunjukkan bahwa sedikitnya ada dua radiasi dalam sejarah evolusi marga. Menurut divergensi dugaan umur, radiasi terjadi pada akhir Miosen dan awal 
Pleistosen. Temuan kami mendukung revisi klasifikasi yang ada dari genus Presbytis dan memungkinkan kita untuk mendiskusikan implikasi-implikasi bagi konservasi. Namun, studi-studi lanjutan termasuk data sekuens nuklir diperlukan untuk dapat memahami secara sepenuhnya sejarah evolusi genus, dan untuk membahas kemungkinan terjadinya hibridisasi di antara taksa.

\subsection{Introduction}

Langurs of the Asian colobine genus Presbytis are exclusively arboreal animals, which inhabit tropical rainforest habitats of Sundaland, i.e., the Malay Peninsula and the western Indo-Malay archipelago (Oates et al. 1994) (Figure 3.1). Most Presbytis species live in unimale matrilineal or female bonded social systems, where males leave their natal troops at puberty (Bennett and Davies 1994; Newton and Dunbar 1994), but female dispersal is also reported (Sterck et al. 1997; Sterck et al. 2005). Mainly driven by Sundaland's dramatic geological and climatic changes during the past million years, the genus has undergone an extensive radiation (Meijaard 2004). With more than 50 described color variants, currently grouped into ten (Brandon-Jones et al. 2004) or eleven species (Groves 2001), Presbytis is one of the most diverse primate genera among Old World monkeys.

The classification of contemporary taxa and the evolutionary history of the genus, however, are poorly understood. Since the seminal work of Napier and Napier (1967), the genus Presbytis has been subject to a long history of frequent taxonomic revisions. Almost all proposed taxonomies and phylogenies for the genus are based on behavioral and anatomical features, largely coat coloration (Brandon-Jones 1978, 1996b, c; Brandon-Jones et al. 2004; Chasen 1940; Groves 1989, 2001; Hooijer 1962; Napier and Napier 1967; Wilson and Wilson 1976), while molecular genetic approaches are limited to a single study (Md Zain 2001). Unfortunately, the conclusions arising from these studies are at best inconsistent and often contradictory. In particular, the taxonomic status of the Sumatran langurs of the melalophos group (Brandon-Jones 2004; Groves 
2001; Md Zain 2001; Md Zain et al. 2002; SAMD 2006) and the Javanese comata group (Brandon-Jones 1995; Brandon-Jones 1996a; Groves 2001; Nijman 1997, 2001) remains to be resolved.

Similarly, the phylogenetic relationships among taxa and the biogeographic history of the genus have yet to be clarified. For example, current reconstructions of the evolutionary history of the genus have yielded entirely conflicting scenarios, one proposing that either the Mentawai langur, P. potenziani (Brandon-Jones 1978, 1996c; Meijaard and Groves 2004) off the west coast of Sumatra, or the Hose's langur, P. hosei (Md Zain 2001), from Borneo is the sister to all Presbytis congeners. Unfortunately, Md Zain (2001) did not sample $P$. potenziani.

In the present study, we analyze a $1.8 \mathrm{~kb}$ long fragment of the mitochondrial genome, including the cytochrome b (cytb) gene, the hypervariable region I (HVI) of the D-loop and the intermediate transfer RNAs (tRNA), from 31 individuals representing nine species. Based on analysis of an extensive range of samples derived predominantly from wild living animals of known location, our results enable us to a) provide the most complete phylogeny of Presbytis available to date, b) estimate divergence times between lineages, c) provide a reliable basis for their taxonomic classification, and d) discuss implications for conservation. 


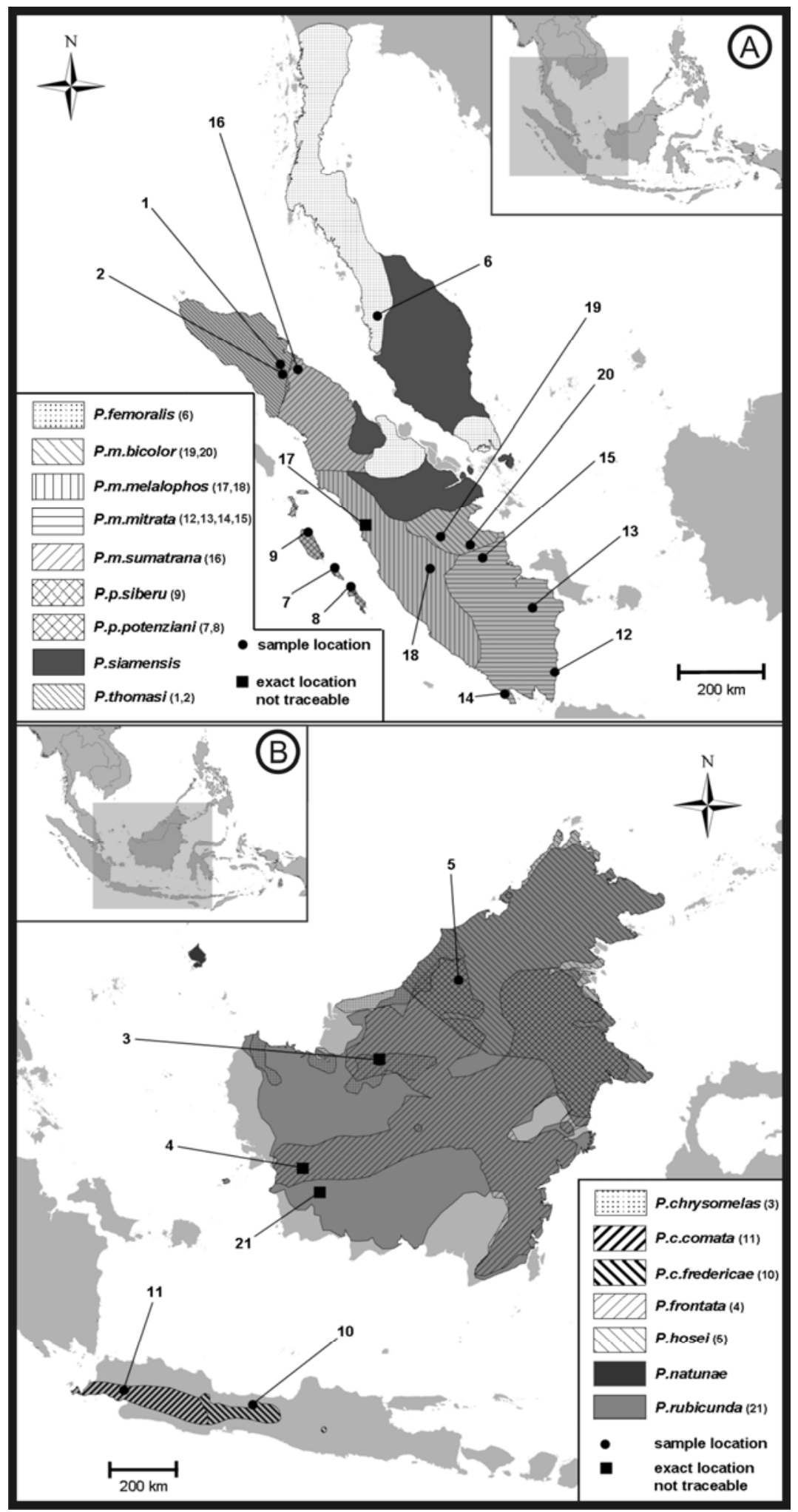

Figure 3.1: Present distribution range of Presbytis on the Asian Mainland, Sumatra and the Mentawai Islands (A) and on Borneo, Java and the Natunae Islands (B). Numbers indicate the origin of samples (see Table 3.1). 


\subsection{Methods}

\subsubsection{Sample collection}

Fecal samples from 15 wild Presbytis populations were collected during two field surveys in September to October 2007 and June to November 2008. The localities spanned the range of $P$. comata (Java), P. melalophos (Sumatra), P. thomasi (Sumatra), P. potenziani (Mentawai Islands) and P. hosei (Borneo) (Figure 3.1). Animals were tracked in the early morning and followed until they defecated. Taxon identity of individuals was ascertained by pelage coloration, morphology, vocalization and geographic origin. The geographical position of the sampling sites was determined by GPS coordinates. Only fresh fecal samples were collected and preserved following the two-step ethanol-silica method described by (Nsubuga et al. 2004). We additionally included two fecal samples from captive animals (P. m. mitrata, Schmutzer Primate Centre of the Ragunan Zoo, Jakarta; P. m. melalophos, Howletts Wild Animal Park, Port Lympne) and four dry tissue samples from museum specimens preserved at the Bavarian State Collection of Zoology (P. frontata, coll. no. 1909/1394; P. rubicunda, coll. no. 1909/784; P. chrysomelas, coll. no. 1909/832; P. m. sumatrana, coll. no. 1921/226).

The skins of the museum specimens were checked for their taxonomic affiliation by examining morphological features particularly pelage coloration and their origin. Tissue samples were stored in plastic bags without any additive. For details about sampling sites see Table 3.1 and Figure 3.1 .

\subsubsection{Laboratory work}

Genomic DNA from feces was extracted using the QIAamp ${ }^{T M}$ Stool Mini Kit from Qiagen following the procedures recommended by the supplier, with the exception that the DNA was diluted in HPLC quality water and stored at $-20^{\circ} \mathrm{C}$ before further processing. 
Table 3.1: Details on the Presbytis samples used in this study (for locations see also Figure 3.1)

\begin{tabular}{|c|c|c|c|c|}
\hline Taxon & Location (Number) & Source & $\begin{array}{l}\text { Sample } \\
\text { Code }\end{array}$ & $\begin{array}{l}\text { Accession } \\
\text { Number }\end{array}$ \\
\hline P. thomasi & Bukit Lawang, Sumatra (1) & Wild & Blaw & JF295124 \\
\hline P. thomasi & Tangkahan, Sumatra (2) & Wild & Tang & JF295125 \\
\hline P. chrysomelas & Kuna, Borneo (3) & Museum & Kun & JF295112 \\
\hline P. frontata & Paian, Borneo (4) & Museum & Pai & JF295113 \\
\hline P. hosei & Bukit Nakan, Sarawak (5) & Wild & Msa & JF295114 \\
\hline P. f. robinsoni & Redang Panjang, Malaysia (6) & GenBank & Mno & DQ355299 \\
\hline P. p. potenziani & Sipora, Mentawai Islands (7) & Wild & Sip & JF295122 \\
\hline P. p. potenziani & North Pagai, Mentawai Islands (8) & Wild & NPag & JF295123 \\
\hline P. p. siberu & Pungut, Menatwai Islands (9) & Wild & Pun1 & JF295121 \\
\hline P. p. siberu & Pungut, Mentawai Islands (9) & Wild & Pun2 & JF295119 \\
\hline P. p. siberu & Pungut, Mentawai Islands (9) & Wild & Pun3 & JF295120 \\
\hline P. c. fredericae & Mt. Slamet, Java (10) & Wild & Sit1 & JF295115 \\
\hline P. c. fredericae & Mt. Slamet, Java (10) & Wild & Sit2 & JF295116 \\
\hline P. c. comata & TN Gunung Halimun, Java (11) & Wild & Hal1 & JF295118 \\
\hline P. c. comata & TN Gunung Halimun, Java (11) & Wild & Hal2 & JF295117 \\
\hline P. m. mitrata & TN Way Kambas, Sumatra (12) & Zoo & Rag & JF295098 \\
\hline P. m. mitrata & TN Way Kambas, Sumatra (12) & Wild & Wk1 & JF295097 \\
\hline P. m. mitrata & TN Way Kambas, Sumatra (12) & Wild & Wk2 & JF295096 \\
\hline P. m. mitrata & Riding, Sumatra (13) & Wild & Rid & JF295099 \\
\hline P. m. mitrata & Way Canguk, Sumatra (14) & Wild & Wc1 & JF295100 \\
\hline P. m. mitrata & Way Canguk, Sumatra (14) & Wild & Wc2 & JF295101 \\
\hline P. m. mitrata & Sungai Gelam, Sumatra (15) & Wild & Gel1 & JF295103 \\
\hline P. m. mitrata & Sungai Gelam, Sumatra (15) & Wild & Gel2 & JF295102 \\
\hline P. m. sumatrana & Deli (Medan), Sumatra (16) & Museum & Med & JF295110 \\
\hline P. m. melalophos & West Sumatra, Sumatra (17) & Zoo & How & JF295105 \\
\hline P. m. melalophos & Bangko, Sumatra (18) & Wild & Ban & JF295104 \\
\hline P. m. bicolor & Bukit Tigapuluh, Sumatra (19) & Wild & Btp1 & JF295109 \\
\hline P. m. bicolor & Bukit Tigapuluh, Sumatra (19) & Wild & Btp2 & JF295106 \\
\hline P. m. bicolor & Bukit Tigapuluh, Sumatra (19) & Wild & Btp3 & JF295108 \\
\hline P. m. bicolor & Sengeti, Sumatra (20) & Wild & Seng & JF295107 \\
\hline P. rubicunda & Paun, Borneo (21) & Museum & Pau & JF295111 \\
\hline
\end{tabular}


DNA from tissue material was extracted with the QIAamp ${ }^{\text {TM }}$ DNA Mini Kit from Qiagen. The complete $1.8 \mathrm{~kb}$ fragment of the mitochondrial genome, which spans the complete cytb gene (1,140 bp), the tRNAs (ca. $140 \mathrm{bp}$ ) for Threonin (tRNA-Thr) and Prolin (tRNA-Pro), and the HVI region of the D-loop (ca. $533 \mathrm{bp}$ ), was amplified via four overlapping fragments using primers listed in Table 3.2. For all amplifications, standard wax-mediated hot-start PCRs were performed. The reactions were carried out in a total volume of $30 \mu \mathrm{l}$ containing a final concentration of $0,33 \mu \mathrm{M}$ of each primer, $3 \mathrm{mM}$ $\mathrm{MgCl}_{2}, 0,166 \mathrm{mM}$ dNTPs, $1 \times$ buffer and $1 \mathrm{U}$ Taq DNA polymerase (Biotherm, Genecraft). PCR conditions for all amplifications were identical and consisted of a predenaturation step at $94^{\circ} \mathrm{C}$ for 2 min., followed by 40 cycles each with denaturation at $94^{\circ} \mathrm{C}$ for 1 min., annealing at variable temperatures (Table 3.2) for $1 \mathrm{~min}$. , and elongation at $72^{\circ} \mathrm{C}$ for $1 \mathrm{~min}$. At the end, a final elongation step at $72^{\circ} \mathrm{C}$ for $5 \mathrm{~min}$. was added. Aliquots of all PCR amplifications were checked on $1 \%$ agarose gels and subsequently cleaned with the Qiagen PCR Purification Kit. Forward and reverse sequences of the PCR products were analyzed on an ABI 3730xI DNA Analyzer (Applied Biosystems) using the BigDye ${ }^{\mathrm{TM}}$ Terminator v1.1 Cycle Sequencing Kit (Applied Biosystems).

To prevent cross-species contamination, laboratory methods followed described standards (Osterholz et al. 2008; Roos et al. 2008; Thinh et al. 2010a; Thinh et al. 2010b). Generated sequences were assembled and edited using Geneious Pro 4.7 (Drummond et al. 2008) and manually checked by eye. The cytb sequences were further checked for their potential to be correctly transcribed. All newly generated sequences were deposited in GenBank and are available under the accession numbers JF295096 JF295125 (see also Table 3.1). 
Table 3.2: Information about primers used in this study. The complete cytb was obtained by amplifying overlapping fragments (primer pairs 6405/6232 and 6435/2068 or 6405/6719 and 6720/6721). The HVI locus was amplified with primer pairs 2067/6234 and 6722/6723. AT: Annealing temperature.

\begin{tabular}{|l|l|l|l|}
\hline Locus & Primer $($ ID) & Primer sequence 5'-3' & AT \\
\hline tRNA-Glu & H-45 uni F (6405) & AAT GAT ATG AAA ARY CAT CGT TG & 58 \\
\hline tRNA-Thr & 15510 R (6232) & TGT CCG TTT CCA GTT TAC AAG & 60 \\
\hline cytb & PresCytbR1 (6719) & TTR TCT GGG TCG CTY AAA AG & 58 \\
\hline cytb & Pre945-F $(6435)$ & TCG CCC AYT TAG CCA ATT CC & 58 \\
\hline cytb & PresCytbF2 (6720) & CTR TTT CTA CAC GAA ACA GG & 58 \\
\hline tRNA-Pro & PresCytbR2 (6721) & AAT ACA GAA AGT AGT TTA AAT AG & 54 \\
\hline HVI & 2068R $(2068)$ & ATT GAT TTC ACG GAG GAT GGT & 56 \\
\hline tRNA-Pro & 2067 F $(2067)$ & CTG GCA TTC TAT TTA AAC TAC TT & 58 \\
\hline HVI & 16220 R (6234) & TGA TAG ACC CGT GAT CCA TC & 58 \\
\hline tRNA-Thr & PresLoopF (6722) & AAA TAC ACC AGT CTT GTA AAC & 54 \\
\hline HVI & PresLoopR (6723) & TTT AAG GGG AAC GTG TGA G & 52 \\
\hline
\end{tabular}

\subsubsection{Statistical analysis}

To expand our dataset, we further incorporated orthologous sequences available at GenBank from one $P$. melalophos (DQ355299) which actually refers due to locality to $P$. femoralis robinsoni (Redang Panjang, Malaysia, pers. comm. Nelson Ting) and one Trachypithecus obscurus (AY863425), which was used as an outgroup. Sequences were aligned with the ClustalW program as implemented in Geneious and manually checked by eye. A computerized method was applied to eliminate poorly aligned positions and divergent regions using Gblocks 0.91b (Castresana 2000). Therefore, a relaxed selection of blocks was selected (Talavera and Castresana 2007). Phylogenetic trees were constructed with neighbor-joining (NJ), maximum-likelihood (ML) and Bayesian approaches. Data were divided into three partitions (cytb, tRNAs, HVI). As the optimal nucleotide substitution model for each partition, the GTR $+I+G$ model was chosen by the Bayesian Information Criterion (BIC) with jModelTest 0.1.1 (Posada 2008). ML analyses were conducted using Garli v0.951 (Zwickl 2006). In Garli, only the model specifications settings were adjusted, while all other settings were left at their default 
values. ML bootstrap percentages were estimated in Garli by performing 500 pseudoreplicate runs. 10 replicates were run to verify consistency in log likelihood scores and tree topologies. A 50\% majority rule consensus tree was calculated with Paup* v4.0b10 (PPC) (Swofford 2003). Phylogenetic relationships based on the NJ algorithm were calculated in Paup. Relative support of internal nodes was performed by bootstrap analyses with 10,000 replications. For the Bayesian analysis in MrBayes v3.1.2 (Huelsenbeck et al. 2001; Ronquist and Huelsenbeck 2003), the dataset was partitioned into the three portions. Four Markov Chain Monte Carlo (MCMC) runs with a default temperature of 0.2 and a chain length of $10,000,000$ generations were carried out. Trees and parameters were sampled every 100 generations. Flat priors were assumed for the model parameters including the proportion of invariable sites and the gamma shape parameter of rate variation among sites. The first $25 \%$ of samples were discarded as burnin, leaving 75,001 trees per run. The adequacy of this burnin and convergence of all parameters was assessed by examining the uncorrected potential scale reduction factor (PSRF) (Gelman and Rubin 1992), which should approach 1 as runs converge, and by visually inspecting the trace of the parameters across generations using the software Tracer v1.3 (Rambaut and Drummond 2005). Posterior probabilities for each split and a phylogram with mean branch lengths were calculated from the posterior density of trees. Phylogenetic trees were visualized with FigTree v1.3.1 (Rambaut 2006).

To estimate divergence times, we included sequences from another 13 primate species, which derived from GenBank (Pongo pygmaeus, NC001646; Pan troglodytes, D38113; Homo sapiens, AY339522; Chlorocebus aethiops, NC007009; Macaca sylvanus, AJ309865; Papio hamadryas, EU885446; Theropithecus gelada, EU885487; Colobus guereza, NC00690; Semnopithecus entellus, EU004478; Rhinopithecus avunculus, EU004480; Nasalis larvatus, EU004476). Due to the high mutation rate in the HVI region, the calculation was performed solely on the cytb sequence data. For the estimation, we applied a Bayesian MCMC method, which employs a relaxed molecular clock approach (Drummond et al. 2006), as implemented in the BEAST v1.5beta2 package 
(Drummond and Rambaut 2007). A relaxed lognormal model of lineage variation and a Yule prior for branching rates was assumed. The alignment was partitioned according to $1+2$ and 3 codon positions. The substitution model, rate heterogeneity and base frequencies were unlinked across codon positions $((1+2), 3)$. As calibration points, we selected the divergence between Hominoidea and Cercopithecoidea (C1), which was dated between 24 and 29 million years ago (Ma) (Zalmout et al. 2010), the divergence between Ponginae and Homininae (C2) 14 Ma (Kelley 2002; Raaum et al. 2005), the split between Homo and Pan (C3) 6-7 Ma (Brunet et al. 2002; Steiper and Young 2006; Vignaud et al. 2002), and the separation of Theropithecus from Papio (C4) $\sim 4 \mathrm{Ma}$ (Delson 2000; Leakey 1993; Ting 2008). Instead of hardbounded calibration points, we used the published dates as a normal distribution prior for the respective node. For $\mathrm{C} 1$ this translates into a normal distribution with a mean of $26.5 \mathrm{Ma}$ and a standard deviation (SD) of $1.36 \mathrm{Ma}$ (95\% credibility interval [CI]: 24-29 Ma), for C2 into a mean of 14.0 $\mathrm{Ma}$ and a SD of 0.60 Ma (Cl: 13.0-15.0 Ma), for C3 into a mean of 6.5 Ma and a SD of 0.31 Ma ( $\mathrm{Cl}$ : 6-7 Ma), and for C4 into a mean of 4.0 Ma and a SD of 0.31 Ma (Cl: 3.5-4.5 Ma). For the analysis, two replicates were run for 25 million generations with tree and parameter sampling occurring every 2,500 generations. The adequacy of a $10 \%$ burnin and convergence of all parameters were assessed by visual inspection of the trace of the parameters across generations using the software Tracer. Subsequently, the sampling distributions of multiple independent replicates were combined with the software LogCombiner v1.4.6 and then summarized and visualized with TreeAnnotator v1.4.6. Both programs are part of the Beast package (Drummond and Rambaut 2007).

\subsection{Results}

In this study, we successfully sequenced a ca. $1.8 \mathrm{~kb}$ fragment of the mitochondrial genome from a total of 30 Presbytis individuals, of which 29 were from known origins. By including an additional sequence from $P$. femoralis from GenBank and following the classification of Groves (2001), our data set comprises nine species and 14 subspecies. Nuclear pseudogenes could not be detected, given that overlapping fragments of dif- 
ferent sequences from the same individual were identical, and that the cytb gene was correctly transcribed. Moreover, the amplification of nuclear pseudogenes (numts) is reduced since we used faecal and museum material in which nuclear DNA is highly degraded (Hofreiter et al. 2003; Thalmann et al. 2004).

The original alignment had a length of $1,816 \mathrm{bp}$. Poorly aligned positions and divergent regions were solely detected within t-RNAs and the HVI. After discarding these positions, the alignment was reduced to $1,745 \mathrm{bp}$. Among them, 172 sites were parsimonyuninformative and 402 parsimony-informative. All sequences represented unique haplotypes.

Phylogenetic reconstructions based on NJ, ML and Bayesian algorithms (Figure 3.2) revealed several strongly supported clades, which mainly referred to species and subspecies. However, although the branching pattern among various lineages gained only weak support, all algorithms showed similar tree topologies.

According to the phylogenetic reconstructions, the base of the tree indicates a separation of $P$. thomasi as the sister species to its congenerics. However, since this initial split is only weakly supported (Bayesian: 77; NJ: 77; ML: 59), we interpret the base of the tree as a polytomy between $P$. thomasi (clade A), clade $\mathrm{B}$, and the remaining Presbytis taxa (clade C). Clade B includes the Bornean species $P$. chrysomelas, $P$. frontata and $P$. hosei, but relationships among them remain unresolved.

In clade C, $P$. femoralis represents the sister lineage to the remaining taxa (clade D), of which P. potenziani (clade E) is separated from the taxa on Sumatra and Java, and also from the Bornean P. rubicunda (clade F). Within P. potenziani (clade E), both subspecies, P. p. potenziani and P. p. siberu, form reciprocally monophyletic clades. Clade $F$ is further divided into subclades $\mathrm{G}$ and $\mathrm{H}$. The former segregates into two strongly supported clades (I and J). The Javanese $P$. comata falls into clade I, which further diverges into two reciprocally monophyletic clades represented by the two subspecies, $P$. c. comata and P. c. fredericae. Clade J consists solely of South Sumatran P. m. mitrata individuals. 


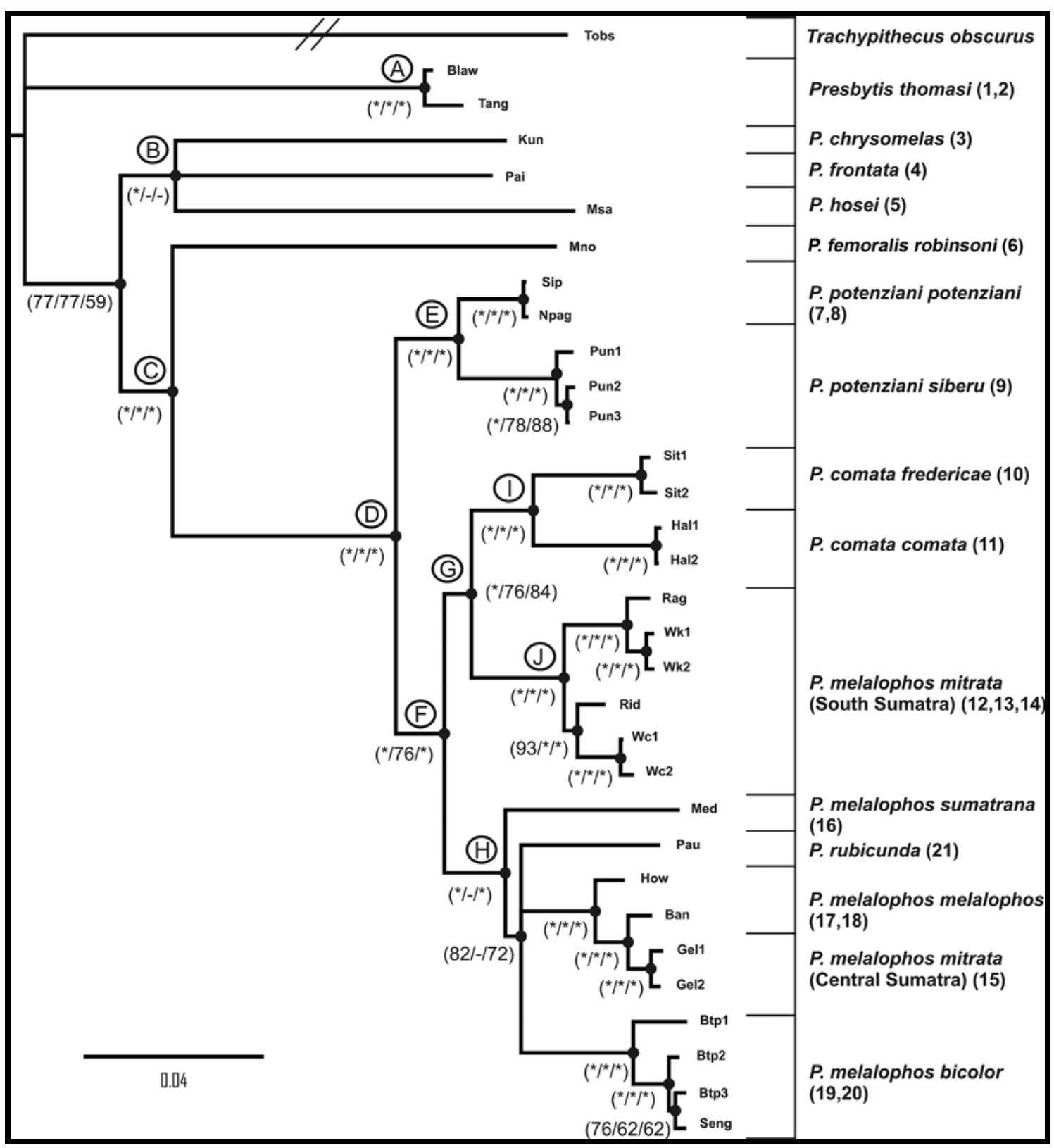

Figure 3.2: Phylogenetic reconstruction derived from Bayesian, $\mathrm{NJ}$ and $\mathrm{ML}$ algorithms based on $1.8 \mathrm{~kb}$ of the mitochondrial genome (for individual sequence codes see Table 3.1). 
Clade $\mathrm{H}$ contains an unresolved polytomy with four highly supported clades or lineages: P. m. sumatrana, P. rubicunda, P. m. bicolor, and a clade formed by P. m. melalophos and P. m. mitrata from Central Sumatra. Thus, P. m. mitrata is mitochondrially paraphyletic.

Based on divergence time estimates (Figure 3.3, Table 3.3), Cercopithecidae separated from Hominidae (C1) 26.57 (24.26-29.09) Ma. Within Hominidae, Pongo branched off first (C2) 13.70 (12.54-14.79) Ma, followed by Homo and Pan (C3), which separated from each other 6.50 (5.92-7.09) Ma. The split between Colobinae and Cercopithecinae (N1) occurred 19.41 (15.81-23.65) Ma. Within the latter, Papionini separated from Cercopithecini (Chlorocebus aethiops) 12.04 (8.97-15.30) Ma (N2). Among Papionini, Macaca diverged first (N3) 10.56 (7.71-13.46) Ma, followed by the differentiation of Papio and Theropithecus (C4) 4.02 (3.44-4.57) Ma. The African colobine genus Colobus separated from Asian colobines 15.39 (12.29-18.98) Ma (N4). Among the latter, the split between Semnopithecus/Nasalis/Rhinopithecus and Trachypithecus/Presbytis took place 12.31 (9.72-14.86) Ma (N5). Semnopithecus separated from Nasalis and Rhinopithecus 10.24 (7.56-12.93) Ma (N6) and latter two 7.51 (5.00-13.10) Ma (N7). The split between Presbytis and Trachypithecus (N8) occurred 11.46 (9.01-14.09) Ma. Within a relative short time period of only 1.43 (3.91-8.53) Ma (N9-N11), four major Presbytis lineages emerged. The first leads to $P$. thomasi, the second to a clade containing $P$. chrysomelas, $P$. frontata and $P$. hosei, the third to $P$. femoralis, and the fourth to a clade including all remaining taxa.

In the latter, a subsequent radiation (N12-N19) leading to species and subspecies started with the separation of P. potenziani 2.62 (1.94-3.38) Ma (N12). Shortly afterwards, 2.22 (1.65-2.85) Ma (N13), South Sumatran P. m. mitrata and P. comata separated from Central Sumatran P. m. mitrata, P. m. melalophos, P. m. sumatrana, P. m. 
bicolor and $P$. rubicunda. In the former, P. m. mitrata diverged 1.8 (1.28-2.37) Ma (N16), before finally $P$. comata split into its two subspecies 1.06 (0.63-1.51) Ma (N19). 


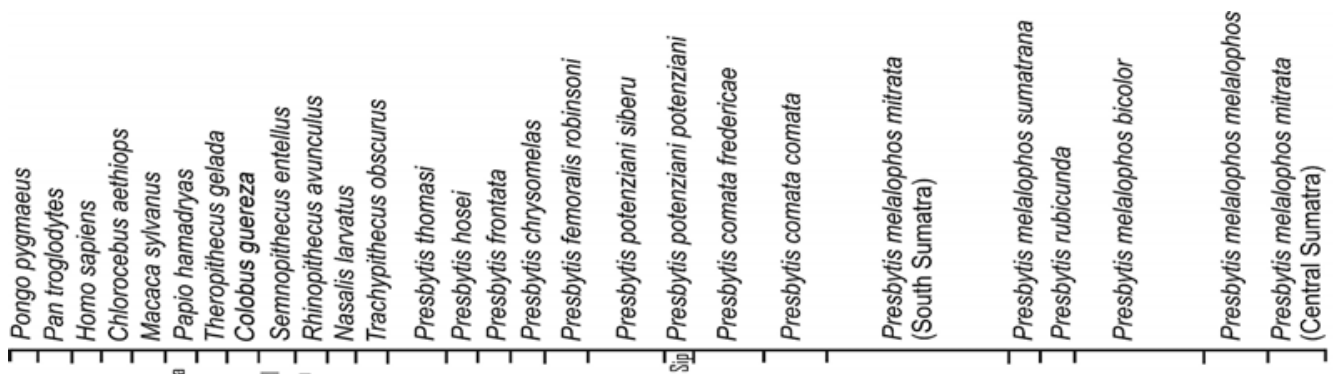

RESIX

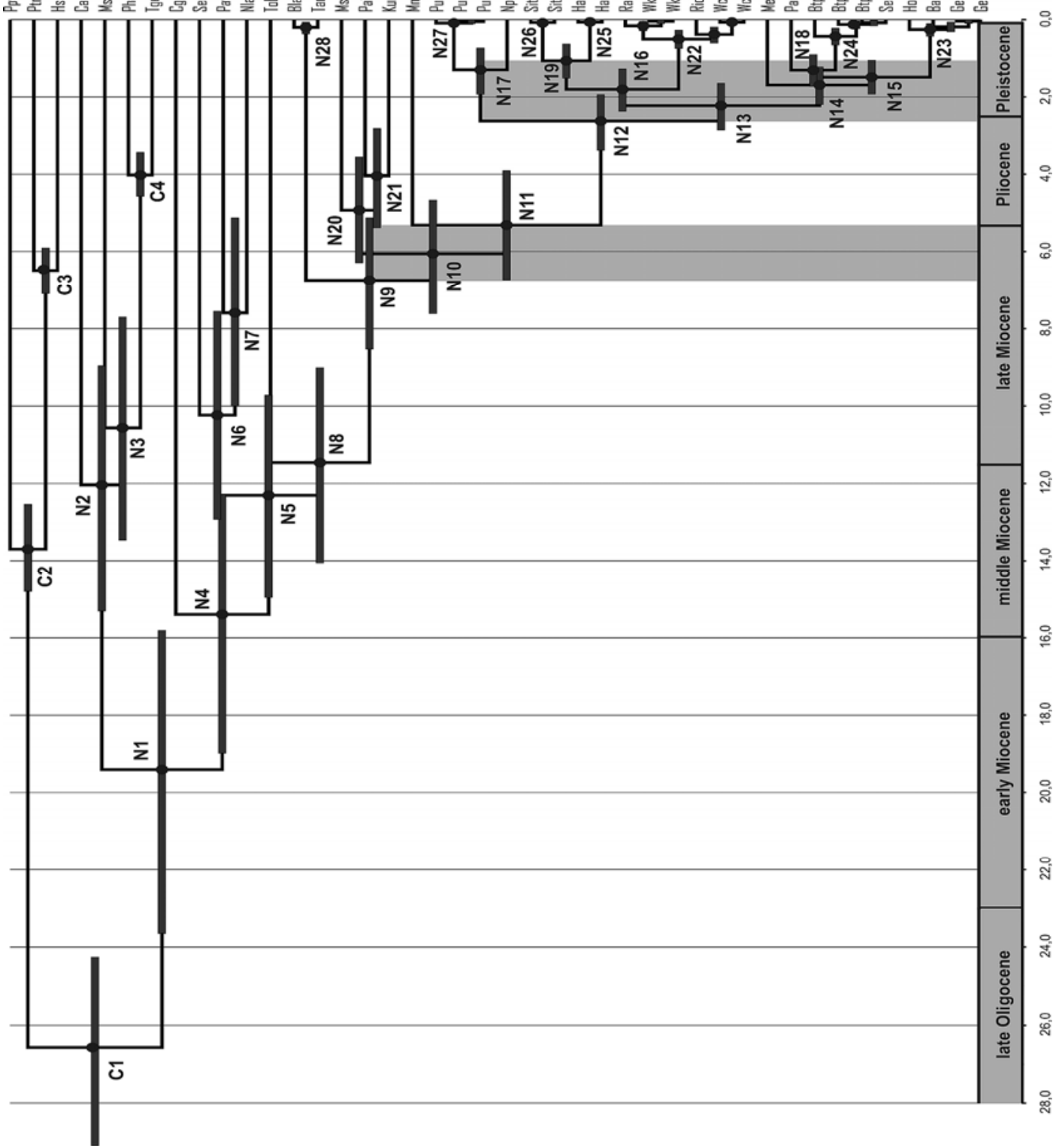

Figure 3.3: Ultrametric tree showing phylogenetic relationships and estimated divergence ages among studied Presbytis individuals based on the complete mitochondrial cytb sequences (for individual codes see Table 3.1). A time scale in million years and the geological periods are given. Nodes of interest are arbitrarily numbered (N1-N28). C1-C4 refer to nodes used for calibration. Light gray bars indicate the two radiations. 
In the latter clade, P. m. sumatrana diverged first (1.69 [1.22-2.20] Ma) (N14), followed by the $P$. m. melalophos/Central Sumatran P. m. mitrata clade 1.40 (0.91-1.93) Ma (N15), before finally $P$. m. bicolor separated from $P$. rubicunda 1.31 (0.91-1.72) Ma (N18).

\subsection{Discussion}

We report here on the analysis of mitochondrial sequences from 31 Presbytis individuals, representing nine of the eleven currently recognized species. Accordingly and since we mainly used only individuals from known locations, this study is the most complete and reliable one up to date. Moreover, calculated divergence ages between various lineages are in similar ranges as earlier estimates (Chatterjee et al. 2009; Raaum et al. 2005; Sterner et al. 2006), although in general slightly older. According to our divergence age estimates, radiations within the genus occurred in two phases, one in the late Miocene and the other in the early to middle Pleistocene.

Interestingly, the tree topology depicted in the only other available molecular phylogeny (Md Zain 2001) differs from our one, although both investigations are based on large segments of the mitochondrial genome, albeit with different samples and loci. In the study by Md Zain (2001), data rely on samples from wild populations from Malaysia, while samples from Indonesia came mainly from captive animals with unknown origin. Unfortunately, sequence data from the earlier study are not available for reanalysis and therefore a discussion of disagreements would remain speculative. However, due to our extensive sampling from clearly identified wild populations, we regard our data as more reliable.

Although $P$. siamensis and $P$. natunae are not represented, the results allow the most comprehensive evaluation of the evolutionary history of the genus to date including material from key taxa such as $P$. potenziani that have not been analyzed before and thus provide a sound basis for a revised taxonomic classification of the Presbytis genus. 


\subsubsection{Phylogenetic relationships}

Based on the grey coat coloration, $P$. thomasi, $P$. hosei and $P$ comata have previously been combined in $P$. comata with a tripartite geographic distribution on West Java $(P$. comata), North Sumatra ( $P$. thomasi) and North Borneo ( $P$. hosei) (Brandon-Jones 1978, 1996b, c; Chasen 1940; Hooijer 1962). Our present data, however, do not support a polytypic $P$. comata species, but instead indicate an early separation of $P$. thomasi and $P$. hosei in respective lineages and a late differentiation of $P$. comata. Concerning $P$. potenziani our data reveal interesting results. Since the discovery of potenziani there have been conflicting statements on its taxonomic position relative to other Asian colobines (Tilson 1976a). Based on postcranial data (Washburn 1944) or infant coloration, potenziani was grouped together with Trachypithecus, while a morphological study by Groves (1970) proposed an intermediate position between Trachypithecus and Presbytis. Subsequent studies of infant coloration(Tilson 1976a) and male vocalization (Wilson and Wilson 1975) grouped potenziani together with Presbytis. The similarity in the adult vocalization between $P$. potenziani and $P$. thomasi led Wilson and Wilson (1976) to conclude that both species are closely related and that a subspecific affiliation might be indicated. Nevertheless, P. potenziani is currently considered as a distinct species (Brandon-Jones et al. 2004; Groves 2001).

Table 3.3: Bayesian divergence date estimates Means and $95 \%$ credibility intervals (Cl) are given for $\mathbf{3 1}$ nodes in Ma. Nodes used as calibration points are labeled with a "C", all others with an "N". MRCA denotes the most recent common ancecestor. ${ }^{a}=$ Mean of divergence times of nodes that belong to unresolved polytomies (see also Figure 3.2; Figure 3.3).

\begin{tabular}{|l|c|c|}
\hline Node & mean (Ma) & $\mathbf{9 5 \%} \mathbf{C l}$ (Ma) \\
\hline C1 Hominoidea - Cercopithecoidea & 26.57 & $24.26-29.09$ \\
\hline C2 Pongo - Pan + Homo & 13.70 & $12.54-14.79$ \\
\hline C3 Homo - Pan & 6.50 & $5.92-7.09$ \\
\hline C4 Papio - Theropithecus & 4.02 & $3.44-4.57$ \\
\hline N1 Cercopithecinae - Colobinae & 19.41 & $15.81-23.65$ \\
\hline N2 Cercopithecini - Papionini & 12.04 & $8.97-15.30$ \\
\hline N3 Macaca - Papio + Theropithecus & 10.56 & $7.71-13.46$ \\
\hline
\end{tabular}




\section{Table 3.3 continued}

\begin{tabular}{|c|c|c|}
\hline Node & mean (Ma) & $95 \% \mathrm{Cl}(\mathrm{Ma})$ \\
\hline N4 Colobus - Asian colobines & 15.39 & $12.29-18.98$ \\
\hline $\begin{array}{l}\text { N5 Semnopithecus + Nasalis + Pygathrix - Trachypithecus + Pres- } \\
\text { bytis }\end{array}$ & 12.31 & $9.72-14.86$ \\
\hline N6 Semnopithecus - Nasalis + Rhinopithecus & 10.24 & $7.56-12.93$ \\
\hline N7 Nasalis - Pygathrix & 7.51 & $5.00-13.10$ \\
\hline N8 Trachypithecus - Presbytis & 11.46 & $9.01-14.09$ \\
\hline N9 P. thomasi - remaining Presbytis taxa & 6.75 & $5.13-8.53$ \\
\hline N10 P. hosei $+P$. chrysomelas $+P$. frontata - remaining taxa & 6.06 & $4.67-7.61$ \\
\hline N11 P. femoralis - remaining taxa & 5.32 & $3.91-6.74$ \\
\hline N12 P. p. potenziani + P. p. siberu - remaining taxa & 2.62 & $1.94-3.38$ \\
\hline $\begin{array}{l}\text { N13 P.c.comata + P.c.fredericae + P.m.mitrata (South Sumatra) - } \\
\text { remaining taxa }\end{array}$ & 2.22 & $1.65-2.85$ \\
\hline $\begin{array}{l}\text { N14 P. m. sumatrana }-P . m . \text { melalophos }+P . m . \text { mitrata (Central } \\
\text { Sumatra) }+P . m . \text { melalophos }+P . m . \text { bicolor }+P . \text { rubicunda }\end{array}$ & 1.69 & $1.22-2.20$ \\
\hline $\begin{array}{l}\text { N15 P. m. melalopho + P. m mitrata (Central Sumatra) - P. rubi- } \\
\text { cunda + P. m. bicolor }\end{array}$ & $\begin{array}{c}1.49 \\
\left(1.40^{\mathrm{a}}\right)\end{array}$ & $\begin{array}{c}1.06-1.93 \\
\left(0.91-1.93^{\mathrm{a}}\right)\end{array}$ \\
\hline N16 P. c. comata + P. c. fredericae - P. m. mitrata (South Sumatra) & 1.80 & $1.28-2.37$ \\
\hline N17 P. p. siberu - P. P. potenziani & 1.30 & $0.74-1.93$ \\
\hline N18 P. rubicunda - P. m. bicolor & 1.31 & $0.91-1.72$ \\
\hline N19 P. c. comata - P. c. fredericae & 1.06 & $0.63-1.51$ \\
\hline N20 P. hosei - P. chrysomelas $+P$. frontata & $\begin{array}{c}4.93 \\
\left(4.49^{\mathrm{a}}\right)\end{array}$ & $\begin{array}{c}3.56-6.29 \\
\left(2.82-6.29^{\mathrm{a}}\right)\end{array}$ \\
\hline N21 P. chrysomelas - P. frontata & 4.05 & $2.82-5.38$ \\
\hline N22 MCRA P. m. mitrata (South Sumatra) & 0.50 & $0.28-0.74$ \\
\hline N23 MRCA P. m. melalophos - P. m mitrata (Central Sumatra) & 0.26 & $0.10-0.43$ \\
\hline N24 MRCA P. m. bicolor & 0.43 & $0.23-0.65$ \\
\hline N25 MRCA P. c. comata & 0.06 & $0.01-0.16$ \\
\hline N26 MRCA P.c. fredericae & 0.07 & $0.00-0.14$ \\
\hline N27 MRCA P. p. siberu & 0.09 & $0.02-0.17$ \\
\hline N28 MRCA P. thomasi & 0.20 & $0.07-0.36$ \\
\hline
\end{tabular}


Based on its morphological and behavioral characters described above, $P$. potenziani is proposed to be the most "primitive" member of the genus and thus the sister species to all congenerics (Brandon-Jones 1978, 1993; Meijaard and Groves 2004). Our molecular data support the monophyly of $P$. potenziani, but neither an early separation, nor a sister grouping with $P$. thomasi.

P. femoralis and P. chrysomelas were originally recognized as subspecies of $P$. melalophos (Napier and Napier 1967; Oates et al. 1994), but later, P. femoralis was separated from $P$. melalophos at the species level, with $P$. chrysomelas being included as a subspecies (Brandon-Jones, 1984). More recently, Groves (2001) proposed species status for P. chrysomelas as well, while Brandon-Jones et al. (2004) kept P. chrysomelas as subspecies of $P$. femoralis. Our data do not support a conspecific relationship between any of these three taxa, since they descend from distinct lineages with ancient divergences.

Of the remaining species, P. comata and P. rubicunda are nested within P. melalophos. Additionally, the possible paraphyletic origin of $P$. m. mitrata, with the central Sumatran populations being closely related to P. m. melalophos and the South Sumatran populations forming a sister lineage to $P$. comata, reflects a puzzling situation of this polyphyletic group. We can not rule out that incomplete lineage sorting might have had an effect. But in the case of incomplete lineage sorting, paraphyletic relationships, like in P. m. mitrata, result from the failure of haplotypes to sort during speciation events and should be random with respect to geography (Avise 2004). This is not the case in our phylogenetic reconstruction, where geographically close populations cluster together. Another explanation might be hybridization between P. m. melalophos and P. m. mitrata. Such a scenario is highly likely, since both taxa are found south of the Batang Hari river (Aimi and Bakar 1992, 1996; Groves 2001) eastwards from Bangko, where we identified $P$. m. melalophos. In addition to our mitochondrial data, the pale reddish coat coloration of the P. $m$ mitrata population from Central Sumatra seems to be intermediate between the red $P$. m. melalophos and the grayish-white Southern P. m. mitrata populations, which is in accordance with the observations of 
Aimi and Bakar (1996). Alternatively, the pale reddish Central Sumatran population might be a further color variant of $P$. m. melalophos. To test these hypotheses, the analysis of nuclear markers is mandatory.

Although the sample size $(n=1)$ of $P$. rubicunda is low, and incomplete lineage sorting might be possible, our data support previous hypotheses, proposing a close affiliation of $P$. rubicunda and P. melalophos based on the red coat coloration (Brandon-Jones 1996b) or in some aspects of behavior and vocalization (Wilson and Wilson 1975).

\subsubsection{Taxonomic implications}

The taxonomic confusion within the genus Presbytis - and also in other primate genera - is associated with much controversial discussion about the recognition on the degree or amount of certain characters, in particular pelage coloration, to recognize species or phylogenetic relatedness. To apply a more objective and falsifiable approach, Groves $(2001,2004)$ suggests the phylogenetic species concept (PSC) to delimit species. The PSC defines a species as the smallest cluster of individual organisms within there is a parental pattern of ancestry and descent and that is diagnosable distinct from other such clusters by a unique combination of fixed character states (Cracraft 1983). At present, the PSC is widely applied in recent studies on primate taxonomy, for example in Mico (Groves 2001), Callicebus (van Roosmalen et al. 2002), Saguinus (Matauschek et al. 2011), Lepilemur (Craul et al. 2007), Microcebus (Louis Jr. et al. 2008), Trachypithecus (Roos et al. 2008) or Nomascus (Thinh et al. 2010b).

Among Presbytis, we detect several highly supported terminal clades or lineages, mainly formed by taxa, which are all also clearly distinguishable in their pelage coloration, thus in agreement with the PSC. Moreover, most of the examined Presbytis taxa differentiated on a similar time scale as did other Asian primates. For example, Tosi et al. (2003) and Ziegler et al. (2007) estimated the divergence between Sundaic and Continental pig-tailed macaques at 1.4 (1.6-1.2) Ma, which afterwards differentiated into respective species. In Trachypithecus, Roos et al. (2008) calculated the divergence between T. germaini and T. margarita 0.95 (1.04-0.86) Ma. Considering estimated di- 
vergence ages and differences in mtDNA and pelage coloration, species status for all examined Presbytis taxa might be appropriate. An overview to the proposed revision in comparison with previous studies is given in Table 3.4.

\subsubsection{Conservation implications}

The rainforests of the Malay Peninsula and the western Indo-Malay archipelago belong to the biodiversity hotspots of our planet, but also to hotspots of environmental degradation. For instance, Indonesia is among the ten countries with the highest number of threatened species (FWI/GFW 2002; World-Bank 2004). The langurs of the genus Presbytis also suffer from this ongoing situation and population sizes of all taxa are still decreasing (IUCN 2010). Reasons for the decline of langurs are manifold, but habitat loss due to forest clearance for agricultural use or timber production, as well as illegal hunting for food, pet trade or traditional medicine, like bezoar stones (visceral secretions used in traditional medicine; (Nijman 2004)), are major threats to wild Presbytis populations.

In particular forest destruction often leads to isolated populations due to fragmentation and consequently to limited or disturbed gene flow. Recent evaluations of the conservation status rank various Presbytis taxa as vulnerable, endangered or even as critically endangered (Table 3.4).

For conservationists it is of great interest whether any population within a taxon is sufficiently differentiated genetically to warrant separate management and also to maintain genetic diversity. In our study we detected several monophyletic clades, which should all be regarded as independent management units (Moritz 1994). Thus, conservation actions are needed for all Presbytis taxa, but especially for the critically endangered ones $P$. chrysomelas and $P$. p. potenziani.

Threats to both taxa are exemplary for most members of the genus. The main threat to P. chrysomelas has been conversion of habitat into agricultural land, resulting in its disappearance from most of its former range and leading to five isolated populations. 
In recent years, the species has in particular been affected by expanding plantations, especially oil palm (IUCN 2010). The population decline of $P$. p. potenziani was estimated at more than $80 \%$ over the past 40 years due to hunting and loss of habitat (Whittaker 2006).

Table 3.4: Proposed classification compared to earlier classifications along with information about type localities, authors and conservation status. ${ }^{a}$ According to IUCN (2010) $P$. c. fredericae is a synonym of $P$. comata ; CS = conservation status (IUCN, 2010), DD = data deficient, $\mathrm{LC}=$ least concern, NT = near threatened, $\mathrm{VU}=$ vulnerable, $\mathrm{EN}=$ endangered, $\mathrm{CR}=$ critically endangered.

\begin{tabular}{|c|c|c|c|c|c|}
\hline Groves (2001) & $\begin{array}{l}\text { Brandon- } \\
\text { Jones et al. } \\
(2004)\end{array}$ & $\begin{array}{l}\text { Proposed } \\
\text { classification }\end{array}$ & $\mathrm{Cl}$ & Author & Type locality \\
\hline P. p. potenziani & P. p. potenziani & P. potenziani & CR & $\begin{array}{l}\text { Bonaparte, } \\
1856\end{array}$ & $\begin{array}{l}\text { Sipora Island, } \\
\text { Mentawai Islands }\end{array}$ \\
\hline P. p. siberu & P. p. siberu & P. siberu & EN & $\begin{array}{l}\text { Chasen \& } \\
\text { Kloss, } 1927\end{array}$ & $\begin{array}{l}\text { Siberut Island, } \\
\text { Mentawai Islands }\end{array}$ \\
\hline P. c. comata & P. comata & P. comata & EN & $\begin{array}{l}\text { Desmarest, } \\
1822\end{array}$ & Java \\
\hline P. c. fredericae ${ }^{a}$ & P. fredericae & P. fredericae & EN & Sody, 1930 & $\begin{array}{l}\text { Mount Slamet, } \\
\text { Central Java }\end{array}$ \\
\hline $\begin{array}{l}\text { P. m. melalo- } \\
\text { phos }\end{array}$ & P. m. melalophos & P. melalophos & NT & Raffles, 1821 & $\begin{array}{l}\text { Bengkulu, } \\
\text { Sumatra }\end{array}$ \\
\hline P. m. mitrata & P. m. mitrata & P. mitrata & EN & $\begin{array}{l}\text { Eschscholtz, } \\
1821\end{array}$ & $\begin{array}{l}\text { Sumatran main- } \\
\text { land } \\
\text { opposite Zutphen } \\
\text { Island }\end{array}$ \\
\hline P. m. bicolor & P. m. bicolor & P. bicolor & DD & $\begin{array}{l}\text { Aimi \& Bakar, } \\
1992\end{array}$ & $\begin{array}{l}\text { Batang Kering, } \\
\text { Sumatra }\end{array}$ \\
\hline P. m. sumatrana & P. m. sumatrana & P. sumatrana & EN & $\begin{array}{l}\text { Müller \& } \\
\text { Schlegel, } \\
1841\end{array}$ & $\begin{array}{l}\text { Mount Talamau, } \\
\text { Sumatra }\end{array}$ \\
\hline P. chrysomelas & $\begin{array}{l}\text { P. femoralis chry- } \\
\text { somelas }\end{array}$ & P. chrysomelas & CR & Müller, 1838 & $\begin{array}{l}\text { Pontianak, } \\
\text { Borneo }\end{array}$ \\
\hline P. thomasi & P. thomasi & P. thomasi & VU & Collett, 1892 & $\begin{array}{l}\text { Langkat, Aceh, } \\
\text { Sumatra }\end{array}$ \\
\hline P. hosei & P. hosei & P. hosei & VU & $\begin{array}{l}\text { Thomas, } \\
1899\end{array}$ & $\begin{array}{l}\text { Niah, Sarawak, } \\
\text { Borneo }\end{array}$ \\
\hline P. rubicunda & P. rubicunda & P. rubicunda & LC & Müller, 1838 & $\begin{array}{l}\text { Mount Sekum- } \\
\text { bang, } \\
\text { South Kaliman- } \\
\text { tan, Borneo }\end{array}$ \\
\hline P. frontata & P. frontata & P. frontata & VU & Müller, 1838 & $\begin{array}{l}\text { Southeastern } \\
\text { Borneo }\end{array}$ \\
\hline P. femoralis & P. femoralis & P. femoralis & NT & Martin, 1838 & Singapore \\
\hline
\end{tabular}


If $P$. c. fredericae is considered to be a separate species it undoubtedly can be ranked among the rarest and most endangered primate species in the world. It would be restricted to four isolated forest areas, none of which are adequately protected and two of them are situated on an active volcano (Nijman 2001).

To protect langurs in the future, urgent actions are required to prevent ongoing habitat destruction and hunting activities. Often captive animals offer the opportunity to conserve and build up a viable gene pool for later release purposes, but in Presbytis, it is of particular interest to protect wild populations since they are difficult to be kept in captivity. However, it is also crucial to confirm the taxon identity and if possible the geographical origin of confiscated animals in general.

\subsection{Conclusions}

We showed that accurate taxonomic identification of Presbytis taxa based on behavioral or morphological data alone is sometimes contradictory or misleading. In this respect, mtDNA analysis is a promising tool, which additionally should be used to answer taxonomic affiliations. This is also important for practical issues in conservation management in nature (in situ) and in captivity (ex situ). As shown in our study, Presbytis taxa can be diagnosed through mtDNA, and, hence, a secure identification of the taxon, even the population, can easily be obtained. In our study for example, we were able to confirm Way Kambas as the origin of the P. m. mitrata sample from the Ragunan Zoo in Jakarta. Yet since mtDNA is only maternally inherited, possible hybrids can not be detected in such analysis. Thus, for the identification of captive hybrids and also to trace possible natural hybridization events as it might be the case between $P$. m. melalophos and the Northern population of $P$. m. mitrata, nuclear markers should be studied as well. Moreover, to fully understand the evolutionary history of the genus, further studies should also include $P$. natunae and $P$. siamensis, as well as a broader sampling set of the Bornean taxa. 


\subsection{Acknowledgments}

Without the help of numerous people and institutions providing permits, samples and giving logistical, physical, and even psychological support, the present study would not have been possible. We thank the Indonesian Institute of Science (LIPI), the Indonesian State Ministry of Research and Technology (RISTEK) and the Indonesian Ministry of Forestry's Department for the Protection Conservation of Nature (PHKA) for granting us research permissions and authorizing this study. We furthermore thank the Gunung Halimun Salak NP, the Gunung Gede Pangrango NP, the Way Kambas NP, the Bukit Barisan Selatan NP, the Siberut NP, the Kerinci Seblat NP, the BKSDA Sumbar, the BKSDA Jambi, the BKSDA Sumsel, the BKSDA Sumut, the BKSDA Bengkulu and the BKSDA Jabar for supporting and authorizing this study. We are grateful to Rinekso Soekmadi and Muhammat Agil from the Bogor Agricultural University (IPB) for their excellent administrative and logistic support. We thank Peter Pratje from the Sumatran Orangutan Conservation Programme (SOCP), Susan Lappan and Sanha Kim (Gibbon research station Gunung Halimun), Pak Opo (Way Canguk), Christophe Abegg from the Siberut Conservation Project (SCP) and Pak Pri (Way Kanan) for the kind opportunity to use their facilities, logistic support and many fruitful discussions. We also thank Danielle Whittaker, Lisa Paciulli, Pak Yanuar and Pak Kunkun Jaka Gurmaya for obtaining important information on promising field sites and contacts. For giving us the opportunity to collect samples, we thank Richard Kraft from the Zoological State Collection in Munich and the Ragunan Zoo Jakarta. We also thank two anonymous reviewers for many helpful comments on the manuscript. This study was financially supported by the German Primate Center and the Biodiversitäts-Pakt of the Wissenschaftsgemeinschaft Gottfried-Wilhelm Leibniz. This publication is dedicated to the field assistants Ambang, Yudi, Aris, Nui, Sahri, Dwi, Insan, Pak Albinus and various rangers for their excellent and sacrificially work during partly exhausting surveys. 


\section{Chapter 4 Acoustic structure of male loud-calls support molecular phylogeny of Sumatran and Javanese leaf monkeys (genus Presbytis)}

\section{Acoustic structure of male loud-calls support molecular phylogeny of Sumatran and Javanese leaf monkeys (genus Presbytis)}

Dirk Meyer ${ }^{1,2^{*}}$, John K Hodges ${ }^{1}$, Dones Rinaldi ${ }^{3}$, Ambang Wijaya ${ }^{3,4}$, Christian Roos ${ }^{5}$ and Kurt Hammerschmidt ${ }^{6}$

\footnotetext{
Abstract

Background: The degree to which loud-calls in nonhuman primates can be used as a reliable taxonomic tool is the subject of ongoing debate. A recent study on crested gibbons showed that these species can be well distinguished by their songs; even at the population level the authors found reliable differences. Although there are some further studies on geographic and phylogenetic differences in loud-calls of nonhuman primate species, it is unclear to what extent loud-calls of other species have a similar close relation between acoustic structure, phylogenetic relatedness and geographic distance. We therefore conducted a field survey in 19 locations on Sumatra, Java and the Mentawai islands to record male loud-calls of wild surilis (Presbytis), a genus of Asian leaf monkeys (Colobinae) with disputed taxanomy, and compared the structure of their loud-calls with a molecular genetic analysis.

Results: The acoustic analysis of 100 surili male loud-calls from 68 wild animals confirms the differentiation of $P$. potenziani, P.comata, P.thomasi and P.melalophos. In a more detailed acoustic analysis of subspecies of $P$. melalophos, a further separation of the southern P.m.mitrata confirms the proposed paraphyly of this group. In concordance with their geographic distribution we found the highest correlation between call structure and genetic similarity, and lesser significant correlations between call structure and geographic distance, and genetic similarity and geographic distance.

Conclusions: In this study we show, that as in crested gibbons, the acoustic structure of surili loud-calls is a reliable tool to distinguish between species and to verify phylogenetic relatedness and migration backgrounds of respective taxa. Since vocal production in other nonhuman primates show similar constraints, it is likely that an acoustic analysis of call structure can help to clarify taxonomic and phylogenetic relationships.
} 


\subsection{Abstract}

Background: The degree to which loud-calls in nonhuman primates can be used as a reliable taxonomic tool is the subject of ongoing debate. A recent study on crested gibbons showed that these species can be well distinguished by their songs; even at the population level the authors found reliable differences. Although there are some further studies on geographic and phylogenetic differences in loud-calls of nonhuman primate species, it is unclear to what extent loud-calls of other species have a similar close relation between acoustic structure, phylogenetic relatedness and geographic distance. We therefore conducted a field survey in 19 locations on Sumatra, Java and the Mentawai islands to record male loud-calls of wild surilis (Presbytis), a genus of Asian leaf monkeys (Colobinae) with disputed taxanomy, and compared the structure of their loud-calls with a molecular genetic analysis.

Results: The acoustic analysis of 100 surili male loud-calls from 68 wild animals confirms the differentiation of P.potenziani, P.comata, P.thomasi and P.melalophos. In a more detailed acoustic analysis of subspecies of P.melalophos, a further separation of the southern P.m.mitrata confirms the proposed paraphyly of this group. In concordance with their geographic distribution we found the highest correlation between call structure and genetic similarity, and lesser significant correlations between call structure and geographic distance, and genetic similarity and geographic distance.

Conclusions: In this study we show, that as in crested gibbons, the acoustic structure of surili loud-calls is a reliable tool to distinguish between species and to verify phylogenetic relatedness and migration backgrounds of respective taxa. Since vocal production in other nonhuman primates show similar constraints, it is likely that an acoustic analysis of call structure can help to clarify taxonomic and phylogenetic relationships.

\subsubsection{Ringkasan}


Latar Belakang: Tingkatan dimana suara panggilan keras pada primata bukan manusia sebagai alat taksonomi yang bisa diandalk an masih menjadi perdebatan. Studi terkini tentang crested Gibbon menunjukkan bahwa spesies ini dapat dibedakan secara jelas lewat lagu mereka; bahkan penulis menemukan perbedaan yang nyata pada tingkat populasi. Walaupun ada studi lebih lanjut mengenai perbedaan geografis dan filogenetik dalam suara panggilan keras spesies primata bukan manusia, masih belum jelas sampai sejauh mana suara panggilan keras spesies lain memiliki hubungan yang dekat dengan struktur akustik, hubungan filogenetik dan jarak geografis. Oleh karenanya kami melakukan survey lapang di 19 lokasi di Sumatra, Jawa dan Kepulauan Mentawai untuk merekam suara panggilan keras surili liar (Presbytis), sebuah genus dari monyet daun asia (Colobinae) yang taksonominya masih diperdebatkan, dan membandingkan struktur panggilan keras mereka dengan analisa genetis molekuler.

Hasil: Analisa akustik dari 100 suara panggilan keras surili jantan dari 68 hewan liar mengonfirmasikan perbedaan P. potenziani, P. comata, P. Thomas dan P. melalophos. Dalam analisa akustik yang lebih detail dari subspesies P. melalophos, pemisahan lebih lanjut dari P. m. mitrata di bagian selatan mengonfirmasi usulan parafili dari kelompok ini. Dalam kaitannya dengan penyebaran geografis mereka, kami menemukan korelasi tinggi antara struktur panggilan dan kemiripan genetik, dan korelasi kurang signifikan antara struktur panggilan dan jarak geografis, dan kemiripan genetik dan jarak geografis.

Kesimpulan: Dalam studi ini kami menunjukkan, yaitu pada crested Gibbon, struktur akustik suara panggilan keras surili adalah alat yang dapat diandalkan untuk membedakan spesies dan untuk menverifikasi hubungan filogenetik dan latar belakang migrasi takson bersangkutan. Karena produksi fokal dalam primata bukan manusia lain menunjukkan hambatan serupa, dapat disebut bahwa analisa akustik struktur panggilan dapat membantu klarifikasi taksonomi dan hubungan filogenetik. 


\subsection{Introduction}

Langurs of the Asian colobine genus Presbytis (surilis) are exclusively arboreal animals, which inhabit tropical rainforest habitats of Sundaland, i.e., the Malay peninsula and the western Indo-Malay archipelago, comprising of Sumatra, Borneo, Java, the Mentawai islands and some smaller interjacent islands (Oates et al. 1994) (for geographical distribution of Presbytis see Figure 3.1 and Figure 4.1). Mainly driven by Sundaland's dramatic geological and climatic changes during the past million years, the genus has undergone an extensive radiation (Meijaard \& Groves 2004). With more than 50 described color variants (Brandon-Jones et al. 2004; Groves 2001), Presbytis is one of the most diverse primate genera among Old World monkeys.

Like many other primate species, surilis emit loud, conspicuous vocalizations termed loud-calls or long-distance calls. In contrast to Presbytis, gibbon loud-calls have a welladapted acoustic structure (Ryan \& Kime 2003; Schneider et al. 2008); with an energy concentration in single frequency bands, a slow modulation of song elements and a transmission range adjusted to the frequency window of rainforest conditions, their songs can be heard over several miles (Padgham 2004; Waser \& Waser 1977). Although less well optimized, loud-calls produced by other nonhuman primate species, such as howler monkeys (Da Cunha \& Byrne 2006) or surilis (Wich et al. 2003), also exhibit adaptations for long-distance transmission. Loud-calls can have a variety of different functions; they may be used to defend resources, to compete for mates, to mediate intergroup spacing and to promote intragroup cohesion (Da Cunha \& Byrne 2006; Waser 1975; Wich \& Nunn 2002). In those species in which the structure of loudcalls is well adapted to long-distance transmission, they function predominantly to mark and defend territories.

Although there is general agreement that loud-calls may also serve as phylogenetic traits, systematic studies comparing call structure and genetic relatedness are rare. Amongst gibbons, structural differences are routinely used as a taxonomic tool (Geissmann 2002; Geissmann \& Nijman 2006). In a recent study on crested gibbons 
carried out in 24 different locations in Vietnam, Laos and Cambodia, Thinh and colleagues (2011) combined a molecular genetic analysis with an acoustic analysis and showed that song structure alone can be used to distinguish the different species. Based on call structure, the authors were also able to distinguish single populations and support not only their phylogentic relatedness, but also their proposed geographic origins. Comparable studies in other nonhuman primates are lacking. However, single studies on loud-calls of orangutans (Ross \& Geissmann 2007), Thomas langurs (Wich et al. 2008), chimpanzees (Mitani et al. 1999), black-and-white colobus monkeys (Oates \& Trocco 1983) or sportive lemurs (Mendez-Cardenaz et al. 2008) revealed geographic or genetic related differences in the structure of loud-calls of these species. Some previous studies proposed that loud-calls of surilis could be a useful tool to characterize phylogenetic relatedness (Aimi \& Bakar 1992; Wilson \& Wilson 1975; 1996). According to these studies, the Sumatran surilis were divided into the species P.melalophos, P.femoralis, P.thomasi (Aimi \& Bakar 1992; Wilson \& Wilson 1975; 1996) and P.potenziani(Aimi \& Bakar 1992; Wilson \& Wilson 1975; 1996), and Wilson and Wilson (1975) proposed a successive invasion of Sumatra, Borneo and the Mentawai islands from the Asian mainland. However, all these studies are only based on phonetic descriptions of loud-calls and did not make a systematic analysis of the acoustic structure or a direct comparison between acoustic structure and genetic relatedness.

Here we combine the results of the most comprehensive molecular genetic study on leaf monkeys of the genus Presbytis currently available (Meyer et al. 2011) with a systematic field survey in which the loud-calls of P.potenziani siberu, P.comata comata, P.thomasi and the four subspecies of P.melalophos (melalophos, mitrata, bicolor and sumatrana) were recorded (Groves 2001). Previous classifications and phylogenies of Presbytis were mainly based on behavioral and anatomical features, in particular coat coloration (Aimi and Bakar 1992, 1996; Brandon-Jones 1996b, 2004; Brandon-Jones et al. 2004; Chasen 1940; Groves 1989, 2001; Hooijer 1962; Napier and Napier 1967; Oates et al. 1994), while genetic studies are extremely limited (Md Zain 2001; Md Zain et al. 2008; Meyer et al. 2011; Vun et al. 2011). In our recent study (Meyer et al. 2011), 
mitochondrial DNA was used to propose a revision of Groves' classification (Groves 2001) suggesting species status for the four subspecies of P.melalophos and also for both subspecies of P.comata and P.potenziani. However, for convenience we use here the classification of Groves (2001).

Since surilis intensively responds to stranger call playbacks (Wich et al. 2002a), we used a playback design in order to collect vocalization data under comparable conditions. We hypothesized that, similar to crested gibbons, structural differences in Presbytis loud-calls reflect phylogenetic relationships and can support a revision of the current classification.

\subsection{Methods}

\subsubsection{Survey locations and data collection}

In 2007 and 2008 we conducted field surveys in 19 locations on Sumatra, Java and the Mentawai islands, and recorded male loud-calls of P.thomasi, P.potenziani, P.melalophos and P.comata (Figure 4.1). To find and track animals the field sites were explored between 5.30 am and 6 am until noon, and in the evening from 3 pm till sundown. When a group was encountered GPS data of the location (using a handheld GARMIn (C GPSMAP 76CSX), information about the group composition and the appearance of the animals (i.e. morphological characters, for instance pelage coloration or scars) were noted on data sheets whenever possible. All visual observations were made by using binoculars ( 8 x 32 Steiner Sky-Hawk).

Since surilis intensively respond to stranger call playbacks (Wich et al. 2002a), we used a playback design to collect data under comparable conditions. Initially, vocalizations were opportunistically recorded to achieve a high quality call of each population. For the playback the quality of the recorded vocalizations was screened on a notebook using AVISOFT SASLAB Pro software version 5.1 (R. Specht, Berlin, Germany). Undisturbed calls from each population were selected and only one of these was used to stimulate response from respective study populations in the same area. At each site, 


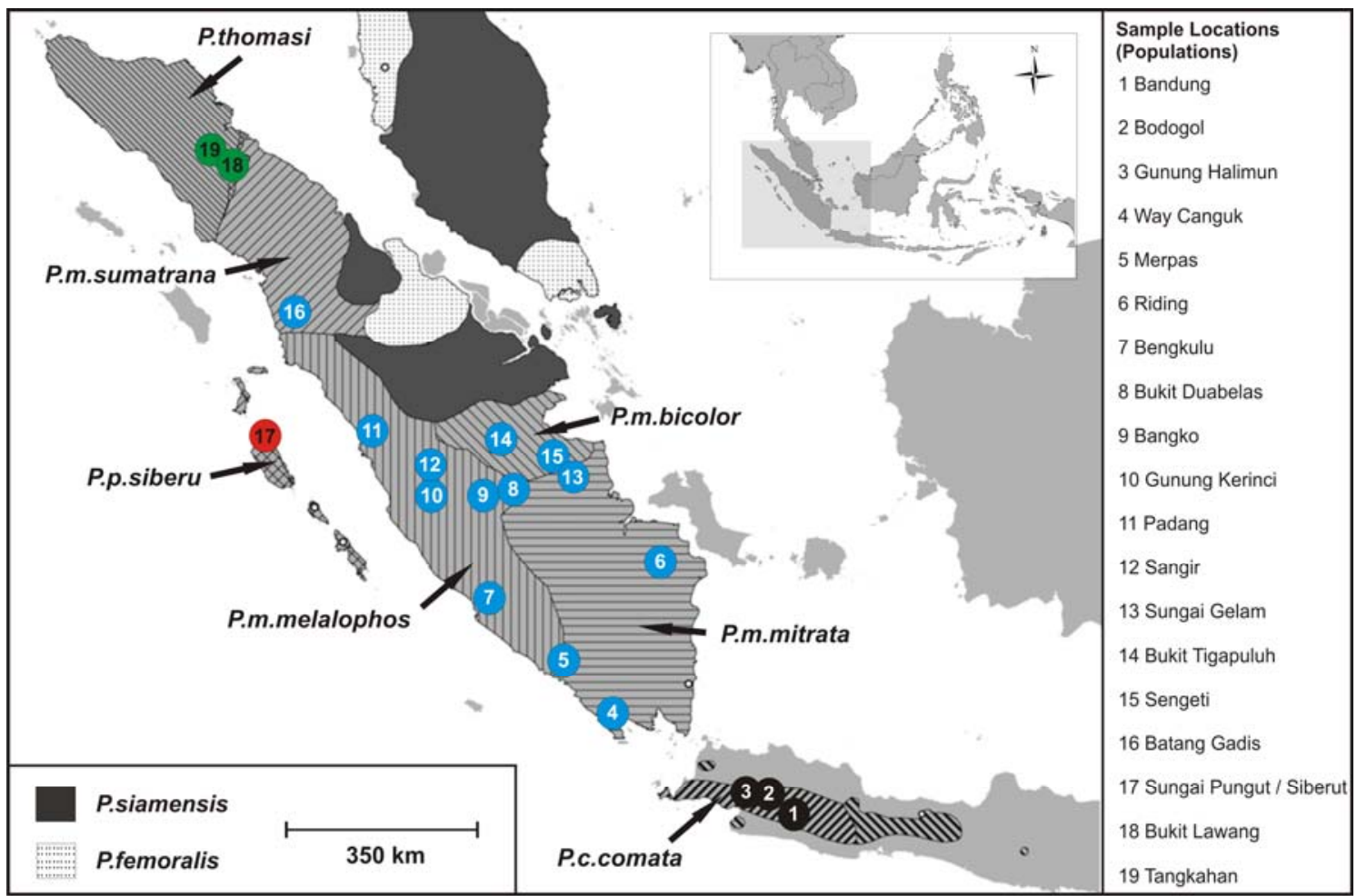

Figure 4.1: Geographical distribution of Presbytis taxa on Sumatra, Java and the Malay peninsula. Sampled taxa are labeled in the map. Hatched areas in the map indicate distribution ranges of respective taxa, colors indicate species and numbers indicate the origin of acoustic samples (populations).

we tried to avoid recording the same individuals by direct observations. Each playback comprised of 4 calls, which were played back one by one in 20 second intervals.

For the final data collection, playback treatments were amplified with a Vision David Speaker connected to a MP3-Player (Samsung YP-U3) from about $75 \mathrm{~m}$ distance of the focal group at a height of $2 \mathrm{~m}$ (Wich et al. 2002a; 2002b). After the performance at least 15 minutes were recorded. If a response was given before the playback was finished the playback was stopped. To record vocalizations a solid state recorder (Mirant PMD 660 (Marantz, Japan); sampling rate: 44.1 kHz, 16 bit amplitude resolution) and a Sennheiser directional microphone (K6 power module, ME66 recording head, MZW66 pro windscreen, Sennheiser, Wedemark, Germany) were utilized. For each playback treatment the GPS position of the location, the group number, the date, time and the identity of a responding male were noted on data sheets. 


\subsubsection{Acoustic analysis}

Male surili loud-calls consist of iterations of single elements. P.thomasi and P.potenziani produce coughing elements at the beginning of the call. In P.thomasi, the successive elements rise in crescendo and increase in volume (see build up phase Figure 4.2), while the coughing elements in P.potenziani are equally loud and noisy. Both loud-calls end with howling tonal phrases including inhalation and exhalation elements (Figure 4.2). We considered these calls as completely developed when both parts were produced. P.comata loud-calls were considered as completely developed when a boost in loudness and frequency till the end of the call was present. P.melalophos loud-calls were considered as completely developed when they included at least 10 elements (the only two calls that were interrupted had less than 10 elements).

AVISOFT SASLAB Pro 5.1 was used to measure acoustic parameters and to generate spectrograms (FFT = 1024 pt, Frequency resolution = app. $27 \mathrm{~Hz}$ ). To find the point with maximum energy at the beginning, ending and intermediate points of call elements in the spectrogram, the bounded reticule cursor tool of AVISOFT was used. To address different phases within loud-calls, each call was additionally divided into four quarters. Since all taxa produce exhalation elements, the amount of exhalation elements (Ex) was therefore divided by 4 and subsequently multiplied by 1, 2, 3 and 4, respectively. Odd numbers were rounded. If inhalation elements $(\operatorname{In})$ were present; the second, third and fourth quarter always started with an exhalation element (for a detailed description of used parameters see Table 4.1 and Figure 4.3). 
Table 4.1: Description of the 23 acoustic parameters that were used in the analysis (numbers of parameters correspond to Additional File 6, for examples see Figure 4.4)

\begin{tabular}{|c|c|}
\hline $\begin{array}{l}\text { Parameter } \\
\text { Number }\end{array}$ & Parameter description \\
\hline 1 & $\begin{array}{l}\text { Duration of the entire call }[s] \text { : from the starting point of the first element till the ending } \\
\text { point of the last element }\end{array}$ \\
\hline 2 & Elements : amount of elements (inhalation and exhalation) \\
\hline 3 & Elements per second [e/s]: amount of elements over the duration \\
\hline 4 & $\begin{array}{l}\text { Maximum frequency start }[\mathrm{Hz}] \text { : maximum frequency of the starting points of the entire } \\
\text { elements }\end{array}$ \\
\hline 5 & $\begin{array}{l}\text { Minimum frequency start }[\mathrm{Hz}] \text { : maximum frequency of the entire starting points of } \\
\text { elements }\end{array}$ \\
\hline 6 & $\begin{array}{l}\text { Maximum frequency end }[\mathrm{Hz}] \text { : maximum frequency of the entire ending points of } \\
\text { elements }\end{array}$ \\
\hline 7 & $\begin{array}{l}\text { Minimum frequency end }[\mathrm{Hz}] \text { : minimum frequency of the entire ending points of } \\
\text { elements }\end{array}$ \\
\hline 8 & $\begin{array}{l}\text { Mean frequency start [Hz]: arithmetic mean of the frequency of the entire starting } \\
\text { points of elements }\end{array}$ \\
\hline 9 & $\begin{array}{l}\text { Mean frequency end }[\mathrm{Hz}] \text { : arithmetic mean of the frequency of the entire ending } \\
\text { points of elements }\end{array}$ \\
\hline 10 & Exhalation elements: amount of exhalation elements \\
\hline 11 & Inhalation elements: amount of inhalation elements \\
\hline 12-15 & $\begin{array}{l}1^{\text {st }}-, 2^{\text {nd }}-, 3^{\text {rd }}-\text { and } 4^{\text {tn }}-\text { quarter elements per second [e/s]: amount of elements over } \\
\text { the duration of respective quarters }\end{array}$ \\
\hline 16 & $\begin{array}{l}\text { Middle part elements per second [e/s]: amount of elements over the duration of the } \\
2^{\text {nd }} \text { and } 3^{\text {rd }} \text { quarter }\end{array}$ \\
\hline $17-20$ & $\begin{array}{l}1^{\text {st }}-, 2^{\text {na }}-, 3^{\text {ra }}-\text { and } 4^{\text {tn }} \text { - quarter mean frequency start }[\mathrm{Hz}] \text { : arithmetic mean of the } \\
\text { frequency of the entire starting points of elements of respective quarters }\end{array}$ \\
\hline 21 & $\begin{array}{l}\text { Middle part mean frequency start [e/s]: arithmetic mean of the frequency of the entire } \\
\text { starting points of elements of the } 2^{\text {nd }} \text { and } 3^{\text {rd }} \text { quarter }\end{array}$ \\
\hline $22-23$ & $\begin{array}{l}1^{\text {st }} \text { and } 2^{\text {na }} \text { - quarter mean frequency end [Hz]: arithmetic mean of the frequency of the } \\
\text { entire ending points of elements of respective quarters }\end{array}$ \\
\hline
\end{tabular}



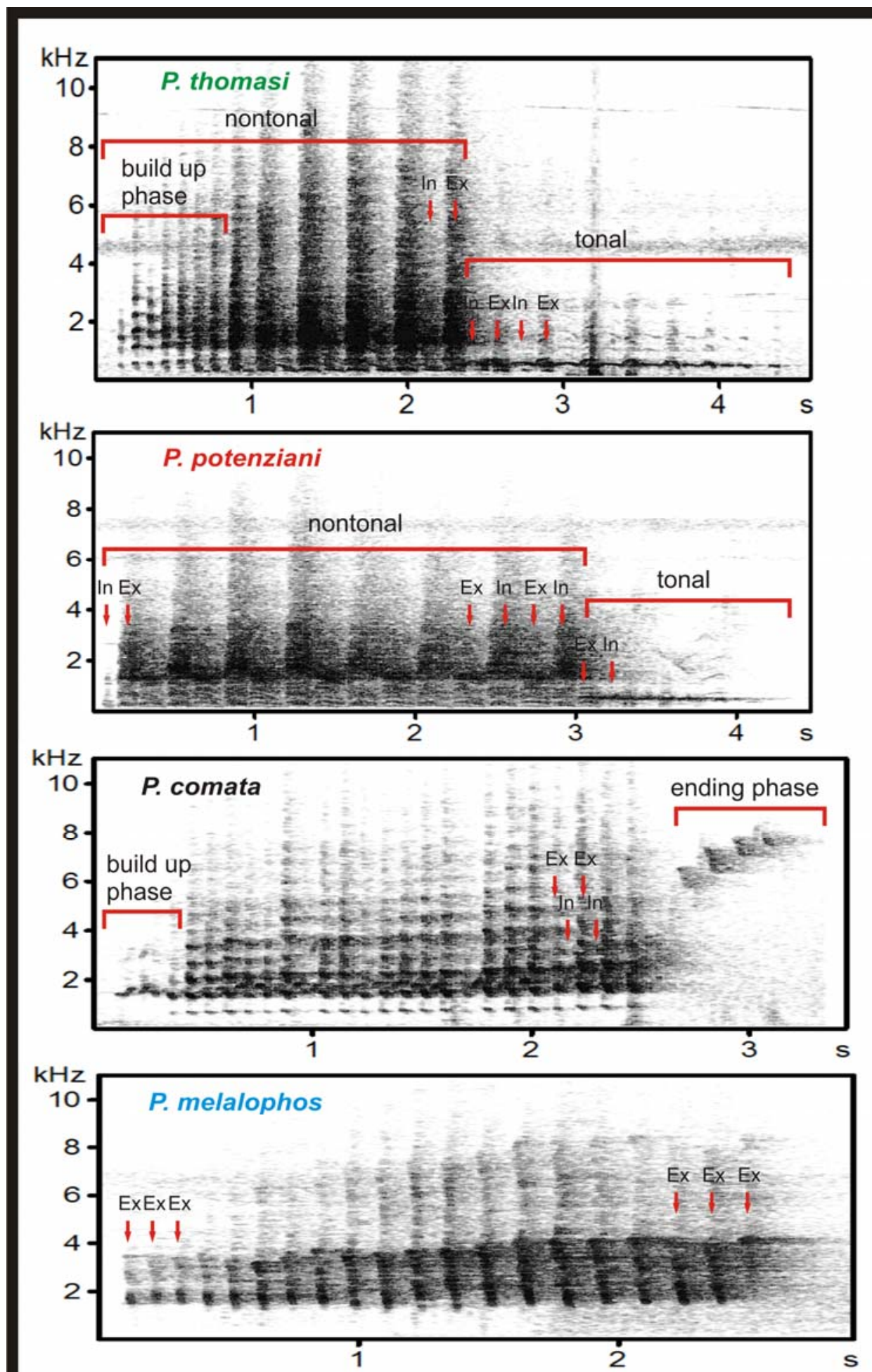

Figure 4.2: Spectrograms of typical loud-calls of P.thomasi, P.potenziani, P.comata and P.melalophos. 


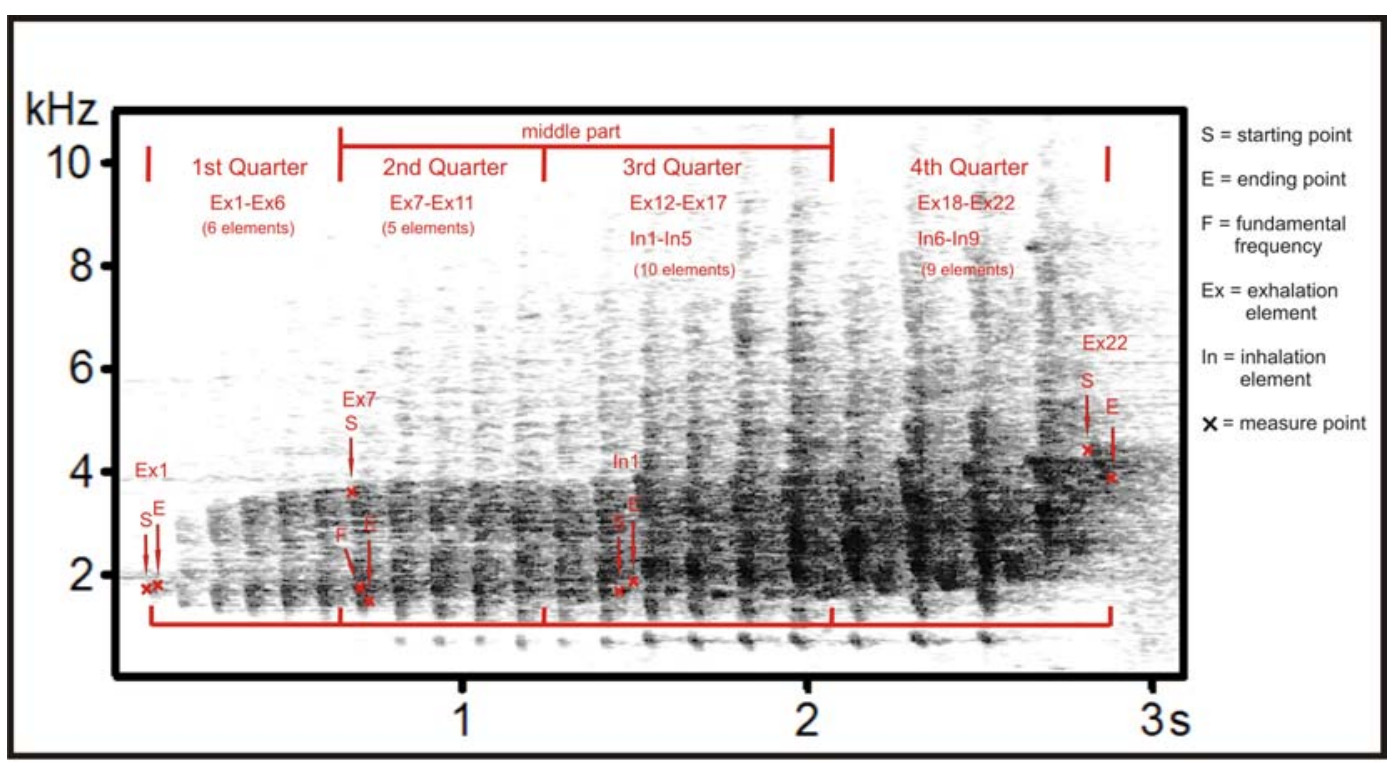

Figure 4.3: Spectrogram of a Presbytis loud-call with examples for the measured parameters.

\subsubsection{Discriminant Function Analysis}

For both Discriminant Function Analyses (DFAs), we excluded acoustic variables that could not be obtained in the majority of loud-calls. In the first DFA we used 23 acoustic parameters for 100 loud-calls from all 19 populations (Table 4.1, Figure 4.1). For the second DFA, including only the four P.melalophos subspecies (melalophos, mitrata, sumatrana, bicolor), we used the same 23 acoustic parameters for 71 loud-calls (population numbers 4-16, Figure 4.1). All acoustic parameters were conducted to stepwise DFAs in SPSS 19 (Meulman \& Heiser 1989). The selection criterion for an acoustic parameter to be entered was $p=0.05$ and $p=0.1$ to be removed from the analysis. The assignment of loud-calls to the different populations was cross-validated by the leaving-one-out method (Brockelman \& Ali 1987), which involves leaving out each of the cases in turn, calculating the functions based on the remaining $n-1$ cases and then classifying the left-out case. 


\subsubsection{Phylogenetic tree reconstruction}

For reconstructing phylogenetic relationships of loud-call structure, we used the F values of pairwise distances of the stepwise DFA described above. These F values describe the pairwise similarity of the 19 populations in relation to their overall similarity. Based on these $\mathrm{F}$ values, a neighbor-joining tree of acoustic data was reconstructed in the program Neighbor of the PHYLIP package 3.69 (Felsenstein 2005). The molecular-based phylogenetic tree derived from mitochondrial sequence data was redrawn from Figure 3.2 (Meyer et al. 2011) and shows only taxa included in the present study. Respective branch lengths refer to those obtained from the Bayesian reconstruction in (Meyer et al. 2011).

\subsubsection{Correlation analysis between vocal structure, genetic and geographical distance}

To test the statistical relationship between acoustic structure, and genetic and geographic distance matrices, we used a Mantel Test algorithm programmed in $R(R$. Mundry, Leipzig, Germany). For the analysis we only used populations where acoustic and genetic data was available $(\mathrm{N}=17)$. The acoustic similarity matrices were generated as described above. Geographic coordinates were obtained via GPS and the geographic distance matrices were calculated from the minimum distance of different groups as implemented in GenAlEx 6.4.1 (Peakall \& Smouse 2006). GenAlEx was also applied to calculate uncorrected pairwise genetic distances between haplotypes of a $1.8 \mathrm{~kb}$ fragment of the mitochondrial genome. Respective haplotypes were recently published by our group (Meyer et al. 2011) (GenBank accession numbers: JF295100-JF295101 [P.m.mitrata], JF295104 [P.m.melalophos], JF295106-JF295109 [P.m.bicolor], JF295117-JF295118 [P.comata], JF295124-JF295125 [P.thomasi], JF295119-JF295121 [P.potenziani]). 


\subsection{Results}

In 2007 and 2008, we conducted field surveys in 19 locations (which resemble 19 populations) on Sumatra, Java and the Mentawai islands, and recorded male loud-calls of seven wild non-habituated Presbytis taxa (Figure 4.1). Included are P.thomasi, P.potenziani siberu, P.comata comata and all four subspecies of P.melalophos (P.m.melalophos, P.m.mitrata, P.m.bicolor and P.m.sumatrana). In total, we recorded more than 300 loud-calls of 68 male individuals.

In response to the playbacks, males often responded several times, but only one call of this bout was used for the analysis (in total 100 calls). Counter calling males in general decreased the distance to the speaker, while females hid or disappeared. A further common response to playback treatments was alarm calling of group members and in addition juveniles often started to squeal (Gurmaya 1986). Loud-calls were mostly accompanied by a jumping display.

\subsubsection{General differences in male loud-calls}

P.thomasi, P.potenziani, P.comata and P.melalophos can be clearly identified by general acoustic characteristics in their call structure (Figure 4.2). In addition, species' calls are readily distinguished by ear, but P.melalophos subspecific differences are undetectable.

P.thomasi $(n=10)$ and P.potenziani $(n=9)$ calls start with coughing elements at the beginning and end with howling tonal phrases. These two parts include inhalation and exhalation elements. In P.thomasi, the initial coughing elements rise in crescendo and increase in volume (build-up phase). In P. potenziani ( $n=9)$, the build-up phase is missing and the coughing elements are equally loud and noisy (Figure 4.2). Both loud-calls also differ in their mean duration with $3.58 \mathrm{~s}(\mathrm{SD}=0.35)$ for P.thomasi and $4.17 \mathrm{~s}$ $(\mathrm{SD}=0.42)$ for P.potenziani. On the average, P.potenziani produces 28 elements $(\mathrm{SD}=2)$ per call with a mean element frequency of 6.42 per second $(S D=0.56)$, while $P$.thomasi produces 30 elements $(S D=4)$ with a mean element frequency of 8.5 elements/s $(S D=1)$ 
(Figure 4.2). Detailed differences in the acoustic structure can be found in Additional File 6.

The typical P.comata call $(n=10)$ is characterized by a unique staccato-like sequence of $52(S D=8)$ alternating exhalation and inhalation elements (mean 18.20, SD=1.91 elements/s). P.comata calls, with a mean call duration of $2.86 \mathrm{~s}(\mathrm{SD}=0.26)$, include a short build-up phase and an end-up phase, both with increasing loudness and frequency (Figure 4.2, Additional File 6).

Loud-calls of P.m.bicolor $(n=15)$, P.m.sumatrana $(n=9)$, the central Sumatran P.m.mitrata $(n=7)$ and P.m.melalophos $(n=26)$ from outside of Bengkulu, consist of a sequence of exhalation elements. An exception are the calls of P.m.melalophos from Bengkulu ( $n=3)$ and the southern Sumatran P.m.mitrata $(n=12)$, which differ by producing alternating exhalation and inhalation elements at the end of the call (Figure 4.4). The mean duration of P.melalophos calls lies between $2.39 \mathrm{~s}(\mathrm{SD}=0.33)$ for P.m.mitrata and $2.53 \mathrm{~s}(\mathrm{SD}=0.40)$ for P.m.sumatrana. The mean frequency of produced elements lies between 10.85 elements/s, (SD=2.36) for P.m.mitrata and 7.35 elements/s (SD=0.4) for P.m.bicolor (Figure 4.4, Additional File 6).

\subsubsection{Subtle differences in male loud-calls}

\section{Result of discriminant function analysis of all 19 populations (DFA1)}

The DFA assigns $72 \%$ of the loud-calls ( $62 \%$ of cross-validated, chance level $=5.3 \%$ ) to the original populations. In relation to taxon identity $83 \%$ of the cross-validated cases are correctly classified. Most misclassified cases are found between P.melalophos subspecies (Table 4.2).

No misclassification can be found between the four Presbytis species, P.comata (populations 1-3), P.melalophos (populations 4-16), P.potenziani (population 17) and P.thomasi (populations 18-19). They form four well separated clusters with a correct assignment of $100 \%$ (Table 4.2, Figure 4.5 A). Among the large P.melalophos cluster, one further sub-cluster is indicated, which includes P.m.melalophos from Bengkulu 

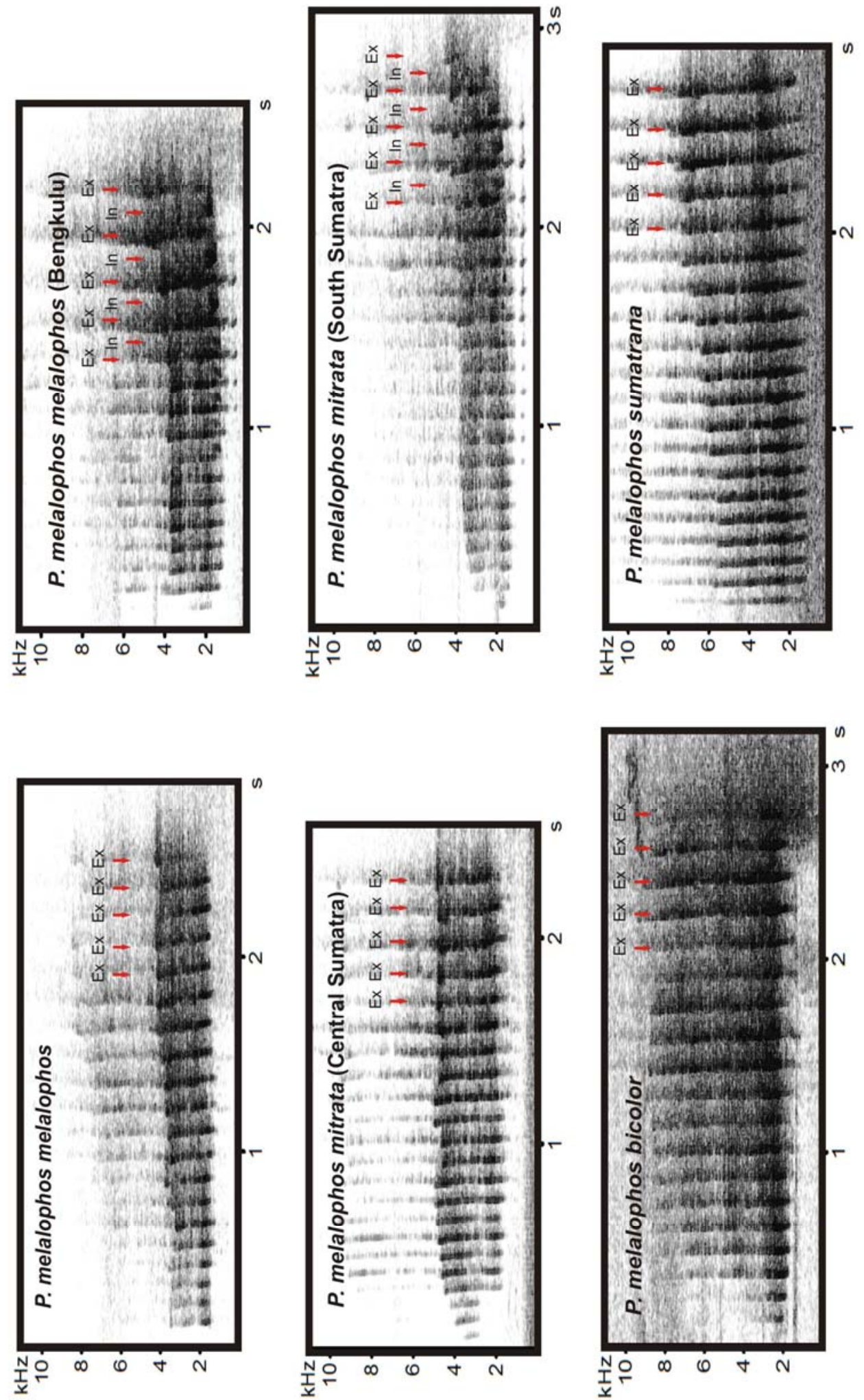

Figure 4.4: Spectrograms of typical loud-calls of P.melalophos subspecies. 
Table 4.2: Classification results of the first and second DFA in relation to the taxon membership. Relative predicted group membership in \% (DFA 1 / DFA 2), $n=$ calls, $P=$ Population(s) number (see also Figure 4.1), I = Individuals.)

\begin{tabular}{|c|c|c|c|c|c|c|c|}
\hline & $\begin{array}{l}\text { P.comata } \\
\mathrm{n}=10 \\
\text { P 1-3 }\end{array}$ & $\begin{array}{l}\text { P.m.mitrata } \\
\text { n=19 } \\
\text { P 4-6, } 13\end{array}$ & $\begin{array}{l}\text { P.m. } \\
\text { mellophos } \\
n=29 \\
\text { P } 7-12\end{array}$ & $\begin{array}{l}\text { P.m. } \\
\text { bicolor } \\
n=15 \\
\text { P 14-15 }\end{array}$ & $\begin{array}{l}\text { P.m. } \\
\text { sumtrana } \\
n=8 \\
\text { P } 16\end{array}$ & $\begin{array}{l}\text { P.potenziani } \\
\text { n=9 } \\
\text { P } 17\end{array}$ & $\begin{array}{l}\text { P.thomasi } \\
\mathrm{n}=10 \\
\text { P 18-19 }\end{array}$ \\
\hline $\begin{array}{c}\text { P.comata } \\
\mid=8\end{array}$ & 100 & & & & & & \\
\hline $\begin{array}{c}\text { P.m.mitrata } \\
\mid=13\end{array}$ & & $68 / 89$ & $26 / 11$ & $6 / 0$ & & & \\
\hline${ }_{\mid=18}^{\text {P.m.melalophos }}$ & & $7 / 7$ & $79 / 76$ & $14 / 10$ & $0 / 7$ & & \\
\hline $\begin{array}{c}\text { P.m.bicolor } \\
\mathrm{I}=13\end{array}$ & & $7 / 0$ & $20 / 7$ & $73 / 93$ & & & \\
\hline P.m.sumatrana & & & $12 / 25$ & $0 / 12$ & $88 / 63$ & & \\
\hline $\begin{array}{c}\text { P.potenziani } \\
\mathrm{I}=4\end{array}$ & & & & & & 100 & \\
\hline $\begin{array}{c}\text { P.thomasi } \\
\mathrm{I}=7\end{array}$ & & & & & & & 100 \\
\hline
\end{tabular}

(population 7) and the southern Sumatran P.m.mitrata (populations 4-6). The scattergram (Figure $4.5 \mathrm{~A}$ ) shows the separation of the 19 populations according to the first and second discriminant function, explaining $56.3 \%$ and $26.7 \%$ of the total acoustic variation, respectively. The first discriminant function, which mainly represents the amount of inhalation elements, separates populations 1-3 from all others, while the second discriminant function, which represents rhythmical features, separates population 17 from all others. To focus on the P.melalophos cluster (populations 4-16), we conducted a second DFA.

\section{Result of the discriminant function analysis of P.melalophos populations (DFA2)}

The second DFA2 assigns $66.2 \%$ of the loud-calls ( $49.3 \%$ of cross-validated, chance level $=7.7 \%$ ) to the original populations and establishes three distinct clusters (Figure 4.5 B), separating the southern Sumatran P.m.mitrata (populations 4-6) and the P.m.melalophos from Bengkulu (population 7) from the remaining P.melalophos populations. 


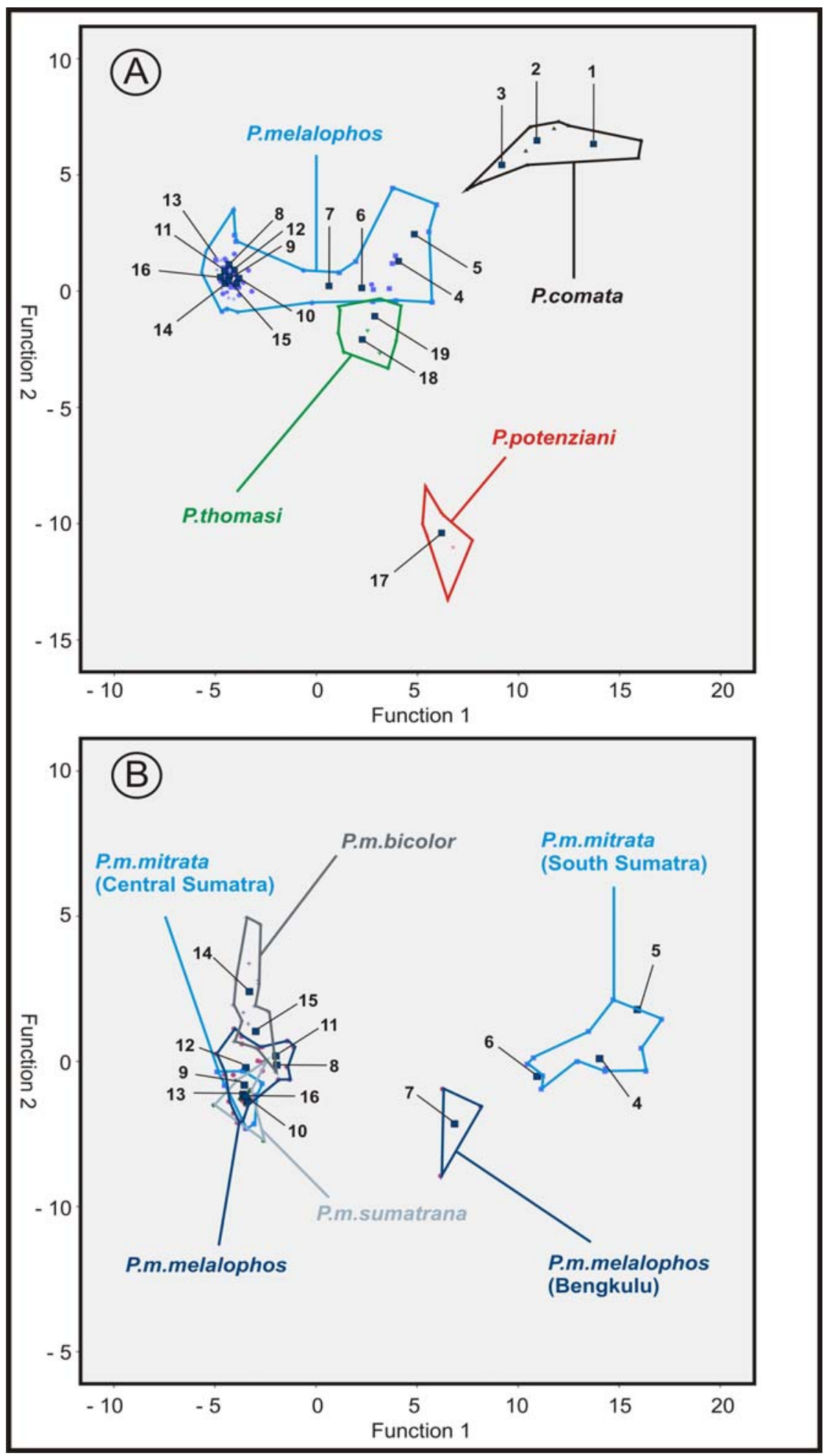

Figure 4.5: Distributions of the different populations belonging to the four species P.melalophos, P.comata, P.thomasi and P.potenziani (A), and to the different P.melalophos subspecies (B). Rectangles indicate population centroids. Taxa are separated by color. 
In relation to the taxon identity $89 \%$ P.m.mitrata, $76 \%$ P.m.melalophos, 93\% P.m.bicolor and 63\% P.m.sumatrana of the cross-validated population cases are correctly classified (Table 4.2). The scattergram (Figure 4.5 B) shows the separation of the 13 populations according to the first and second discriminant function, explaining $92.9 \%$ and $3.8 \%$ of the total variation, respectively. The first discriminant function, which explains nearly all structural differences, represents the amount of inhalation elements, separates populations 4-6 from population 7, and the remaining populations. The second discriminant function mainly based on the minimum frequency of the call, indicates the separation of populations 14, 15 and 5 from population 7 and the lasting locations.

\subsubsection{Correlation between vocal structure, genetic and geographical distance}

A Mantel test was performed to test the concordance between genetic distance, geographical distance and acoustic similarity. All populations where corresponding genetic data was available $(\mathrm{N}=10)$ were included in the analysis. We found highest significant correlations between the vocal structure and genetic distance $\left(P=0.001, R_{X Y}=0.91\right)$, and lower significant correlations between vocal structure and geographical distance $\left(P=0.001, R_{X Y}=0.662\right)$, and geographical distance and vocal structure $(P=0.001$, $\mathrm{R}_{\mathrm{XY}}=0.663$ ) between population 3 (P.comata), populations 4,6,13 (P.m.mitrata), popu-

lation 9 (P.m.melalophos), populations 14, 15 (P.m.bicolor), population 17 (P.potenziani) and populations 18, 19 (P.thomasi) (for details on the locations see Figure 4.1). 


\subsubsection{Phylogenetic relationships among Presbytis taxa based on acoustic data and comparison with molecular data}

The vocal- (Figure 4.6 A) and molecular-based phylogenies (Figure 4.6 B) (Meyer et al. 2011) are highly congruent. In both phylogenies, P.thomasi, P.potenziani, P.melalophos (excluding P.m.mitrata from South Sumatra) and P.comata + P.m.mitrata from South Sumatra form four distinct clusters/lineages and indicate a similar branching pattern. Contrary to the molecular phylogeny, in the acoustic tree P.m.mitrata from South Sumatra (populations 4-6) does not form a monophyletic cluster, and P.m.sumatrana (population 16) and P.m.bicolor (populations 14-15) are nested within the cluster consisting of P.m.melalophos and P.m.mitrata from Central Sumatra (populations 7-13). This might be due to the subtle differences found in the vocal structure of respective populations.

\subsection{Discussion}

Here we report significant differences between loud-call structures of P.thomasi, P.potenziani, P.comata and P.melalophos. Among the latter species a significant separation between the South Sumatran P.m.mitrata and the central Sumatran P.m.mitrata, as well as a further separation between P.m.melalophos from Bengkulu and the remaining P.m.melalophos populations, could be detected. The acoustic discrimination between Presbytis taxa was highly positively correlated with their genetic distance. In addition, we found substantial significant correlations between acoustic similarity and geographic distance and between genetic distance and geographic distance.

In our recent molecular genetic study (Meyer et al. 2011) we suggested a paraphyly for P.m.mitrata, with the central Sumatran populations being closely related to P.m.melalophos and the South Sumatran populations forming a sister lineage to 


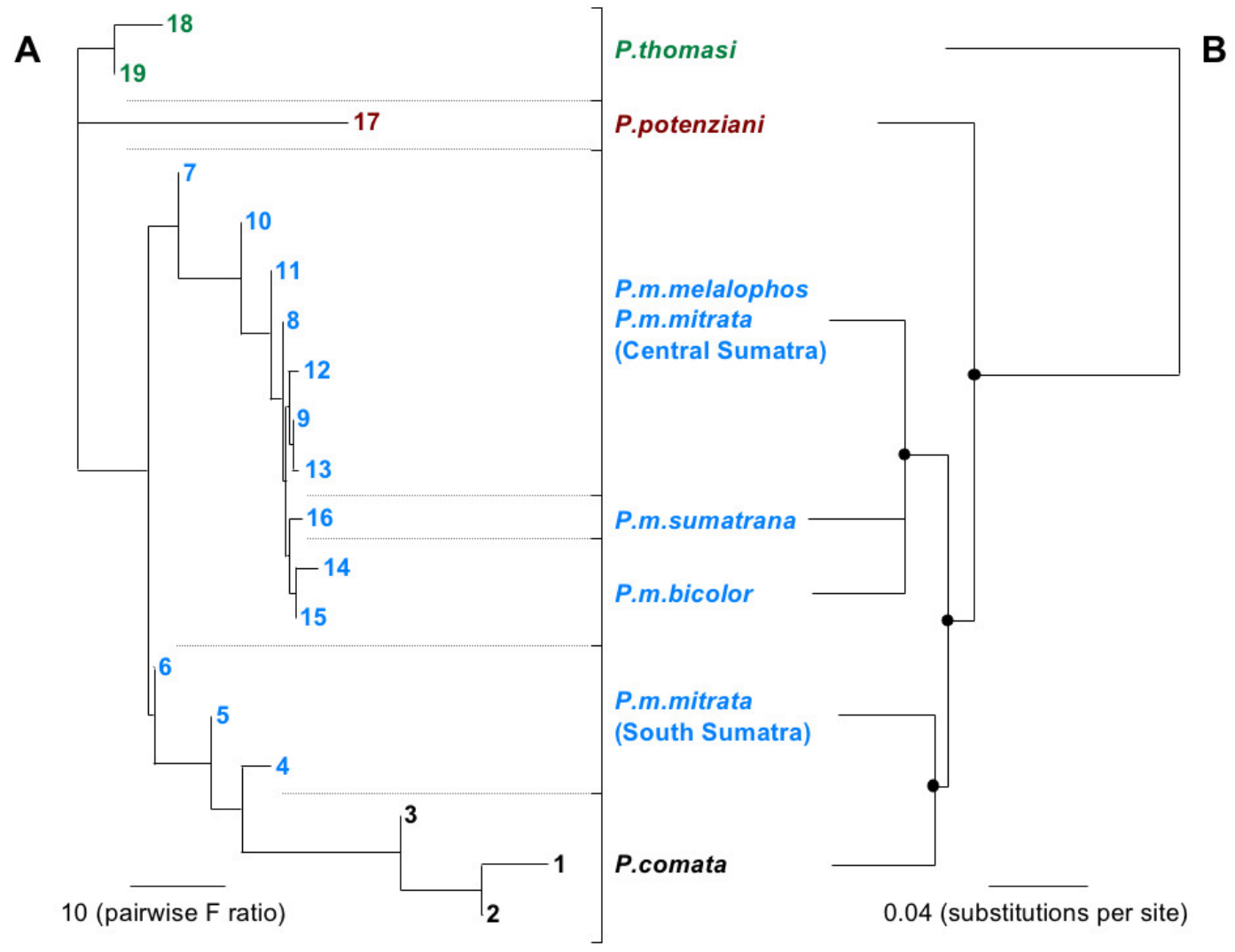

Figure 4.6: (A) Neighbor-joining tree of Presbytis taxa based on the acoustic similarity matrix ( $F$ values) and $(B)$ their phylogenetic relationships according to mitochondrial sequence data (redrawn from Meyer et al. (2011)). In A, colored letters indicate species and numbers corresponding to sampling locations (see Figure 4.1). In B, branch lengths refer to those obtained from the Bayesian reconstruction in Meyer et al. (2011) and black dots on nodes indicate Bayesian posterior probabilities of $>0.96$.

P.comata (Figure 4.6 B). Our current findings on the acoustic structure of loud-calls strongly support these results.

P.m.mitrata was reported to inhabit the area southeast of the Batang Hari River, a large river in central Sumatra. In the west, this subspecies does not extend to the Bukit Barisan range, a mountain range on the western side of Sumatra (Aimi \& Bakar 1996), where P.m.melalophos occurs (Groves 2001). Our samples of the central Sumatran P.m.mitrata (population 13) derived from the above described northernmost distribution range of this subspecies, south of the Batang Hari river. Although much paler, the morphological appearance resembles the reddish P.m.melalophos more than the gray- 
ish white southern Sumatran P.m.mitrata (Additional File 7). Whether there might be a transition zone between P.m.melalophos and P.m.mitrata demands further research. It is highly likely that P.m.melalophos gradually intergrades with P.m.mitrata, as may be the case between P.m.bicolor and P.m.melalophos (Aimi \& Bakar 1996). Our results, however, let us conclude that the central Sumatran P.m.mitrata population is the paler color variant of P.m.melalophos. Thus, the geographical distribution range of P.m.melalophos should be extended from the Bukit Barisan range eastwards towards Jambi. The southern Sumatran P.m.mitrata is genetically, morphologically and acoustically distinct from the remaining P.melalophos subspecies (see also Additional File 7). Therefore, if the Phylogenetic Species Concept (Cracraft 1983; 1989) is applied, P.m.mitrata would be elevated to a monotypic species P.mitrata Eschscholtz, (1821).

Among P.m.melalophos we found the calls from Bengkulu (population 7) forming a distinct cluster. Unfortunately, genetic data from Bengkulu are lacking, but acoustically, the call types were more closely related to the Southern P.m.mitrata mainly due to the presence of inhalation elements. Historically different color morphs of P.m.melalophos were described, all of which are currently classified as synonyms of P.m.melalophos (Groves 2001). These are a) the much less red and buffer variant from Bengkulu (Simia melalophos Raffles, 1821; syn. flavimanus Geoffroy, 1830), b) a foxy red northern form (Presbytis nobilis Gray, 1842) from Solok [4], c) a less reddish form from Padang (Semnopithecus ferruginneus Schlegel, 1876) and d) a golden buff variant (Semnopithecus sumatranus var. aurata Müller \& Schlegel, 1841) from Gunung Talamau (ca. $150 \mathrm{~km}$ northwards from Padang) (Groves 2001). The great diversity of color morphs in Presbytis, in particular in P.melalophos, has caused much debate over the past decades. Coloration might indicate relatedness, but can often be misleading, in particular, when no broad geographic sampling is available. Our data point out that the taxonomic ranking of some of these historically described taxa possibly should be reconsidered. However, the loud-calls from population 7 are only derived from two individuals and genetic data are missing. Therefore, further molecular genetic and bioacoustic research based on a broader sampling is needed to draw final conclusions. Of 
great interest are the acoustic data of the Bornean taxa, in particular data of P.rubicunda. Based on molecular genetic results P.melalophos is even polyphyletic since P.rubicunda is nested within the P.m.sumatrana, P.m.bicolor, P.m.melalophos/central Sumatran P.m.mitrata clade (Meyer et al. 2011). Previous studies already proposed a close affiliation of P.rubicunda and P.melalophos based on the red coat coloration (Brandon-Jones 1996b) or in some aspects of behavior and vocalization (Wilson \& Wilson 1975). If species status of P.rubicunda is retained, species status of P.m.sumatrana, P.m.bicolor, P.m.melalophos will be consequently warranted, otherwise P.rubicunda has to be assigned as a subspecies of P.melalophos.

The correlation between acoustic structure and genetic differences was higher than the correlation between acoustic structure and geographic distance. This pattern can be explained by the following proposed Presbytis migration pattern, which is largely in agreement with Wilson and Wilson (1975). The initial split in Presbytis occurred between P.thomasi and all other taxa, and P.thomasi colonized North Sumatra, which became isolated afterwards. The ancestor of the remaining taxa colonized first Borneo and later Sumatra. An early divergence of Bornean taxa is also supported by previous genetic studies (Md Zain 2001; Md Zain et al. 2008; Meyer et al. 2011; Vun et al. 2011). Of the ancestral Sumatran stock, one lineage invaded the Mentawai islands (P.potenziani), the other split into the proto-P.melalophos lineage and into the southern P.m.mitrata/P.comata lineage (Figure 4.6). Although calls from P.femoralis/P.siamensis (eastern Sumatra, Asian mainland) are not analysed in our study, previous publications show similarities in call structures of P.femoralis and P.thomasi (Kawamura 1984; Megantara 1989). Our genetic study (Meyer et al. 2011) shows that P.femoralis diverged relatively early from other lineages and, thus, the similar call structure of P.femoralis and P.thomasi might be a plesiomorphic feature. Up to this point the genetic, geographic and acoustic differences between populations increased. From this point onwards the geographic distances between populations decreased, because proto-P.melalophos subsequently transmuted into various present day subspecies, which were finally distributed across Sumatra as far as to the distribu- 
tion range of $P$.thomasi in North Sumatra. Consequently, the geographic distance between P.thomasi and the remaining Sumatran populations decreased, while the genetic and the acoustic differences increased. Finally, the southern P.m.mitrata/P.comata lineage split into P.m.mitrata and P.comata that colonized Java. In this case we have a linear migration pattern and thus would expect a similar high correlation between acoustic structure, genetic and geographic distance, as it was currently shown in crested gibbons which are proposed to migrate in a linear fashion from North to South (Thinh et al. 2011).

Surilis and gibbons are limited to rainforest habitats where the selection pressure forces an optimal adaptation of the structure of loud-calls for transmission over longer distances (Schneider et al. 2008; Ey \& Fischer 2009). Since the structure of loud-calls is inherited and call adaptation forces a similar structure, gene flow could achieve the major influence on the structural variation of calls (Thinh 2011). By combining the phylogenetic reconstruction of Meyer and colleagues (2011) and the results of our study (Figure 4.2, Figure 4.6 A), we can observe a trend to simplification in call structure over time. However, it is difficult to explain why we found such a simplification in call structure. We cannot answer whether this is a general rule or whether this is a Presbytisspecific trait. Crested gibbons show an ambiguous result (Thinh et al. 2011), where after a long period of syllable types with simple frequency modulation, a trend to a slightly more complex modulation appears. More acoustic comparisons with more species and at a higher taxonomic level are necessary to answer this question. Interestingly, P.potenziani was regarded as most basal lineage (Brandon-Jones 1993) and due to similarities in call structure, the species was proposed as closely affiliated with P.thomasi (Wilson \& Wilson 1976). However, neither is the case, since P.potenziani derived much later (Meyer et al. 2011). The specific call structure of P.potenziani is therefore either the result of an analogous evolution or a pleisiomorphic Presbytis feature. To clarify this issue further research is needed and particularly genetic and acoustic data on the Bornean and Malaysian taxa will help to better understand the evolution and phylogeography of the genus. 
For instance, the call structure of P.rubicunda seems to be similar to P.melalophos calls (Wilson \& Wilson 1975) and, as discussed above, molecular genetic data also group P.rubicunda with P.melalophos (Meyer et al. 2011). This close relationship can partly help to explain the interesting feature of general allopatry of respective Presbytis taxa in Sumatra, and sympatry in Borneo (Oates et al. 1994). P.rubicunda originated on Sumatra and subsequently invaded Borneo during the middle Pleistocene via a proposed connection between both islands (Meijaard 2004). At this time Borneo was already colonized by the Bornean species P.chrysomelas, P.frontata and P.hosei. As a result of this second colonization, P.rubicunda is sympatric today with the three other species wherever their ranges overlap (Nijman 2010).

\subsection{Conclusions}

In this study we have shown that vocal similarity highly correlates with genetic relatedness; these two measures also correlate significantly with geographic distance, but the strength of the relationship is lower. Accordingly, acoustic analysis of surili loudcalls has been proven to be a promising and powerful tool to support taxon-affiliation and phylogenetic relatedness. In addition, we were able to confirm the proposed paraphyly of P.melalophos by differences in loud-call structure. Furthermore, acoustic analysis can be used as a tool to support proposed migration routes. These findings might also help to explain taxonomic relationships and migration backgrounds in other nonhuman primate taxa, as long as they have similar constraints in their vocal communication.

\subsection{Acknowledgements}

Without the help of numerous people and institutions providing permits, samples and giving logistical, physical, and even psychological support, the present study would not have been possible. We thank the Indonesian Institute of Science (LIPI), the Indonesian State Ministry of Research and Technology (RISTEK) and the Indonesian Ministry of Forestry's Department for the Protection Conservation of Nature (PHKA) for granting 
us research permission and authorizing the study. We also thank the Gunung Halimun Salak National Park (NP), the Gunung Gede Pangrango NP, the Way Kambas NP, the Bukit Barisan Selatan NP, the Siberut NP, the Kerinci Seblat NP, the Balai Konservasi Sumber Daya Alam (BKSDA) Sumbar, the BKSDA Jambi, the BKSDA Sumsel, the BKSDA Sumut, the BKSDA Bengkulu and the BKSDA Jabar for supporting and authorizing field data collection in this study. We are grateful to Rinekso Soekmadi and Muhammad Agil from the Bogor Agricultural University (IPB) for their excellent administrative and logistic support. We thank Peter Pratje from the Sumatran Orangutan Conservation Programme (SOCP), Susan Lappan and Sanha Kim (Gibbon research station Gunung Halimun), Pak Opo (Way Canguk), Christophe Abegg from the Siberut Conservation Project (SCP) and Pak Pri (Way Kanan) for the kind opportunity to use their facilities, logistic support and many fruitful discussions. We also thank Danielle Whittaker, Lisa Paciulli, Pak Yanuar and Pak Kunkun Jaka Gurmaya for obtaining important information on promising field sites and contacts and Julia Fischer, Dietmar Zinner and Peter Kappeler for their support. This study was financially supported by the German Primate Center and the Biodiversitäts-Pakt of the Wissenschaftsgemeinschaft GottfriedWilhelm Leibniz. This publication is dedicated to the field assistants Yudi, Aris, Nui, Sahri, Dwi, Insan, Pak Albinus and various rangers for their excellent work during the long and exhausting field surveys. 


\section{Chapter 5 General discussion}

\subsection{Summary of results}

Leaf monkeys are a very diverse group of primates which developed a great degree of unique adaptations along their evolutionary history. Eight species of leaf monkeys are listed among the 25 most endangered primates in the world (Mittermeier et al. 2009), but until now they receive less scientific attention. This dissertation was designed to elucidate aspects of phylogeny, taxonomy and phylogeography of leaf monkeys with particular focus on the genus Presbytis. Molecular, acoustic and distributional data from various data sources, including museum collections, sequence data from GenBank, and most importantly new data collected from the field were used to answer the following questions:

1. What can be concluded from the re-examination of the leaf monkey phylogeny regarding Presbytis?

- What is the phylogenetic position of Presbytis among the Asian colobines?

Phylogenetic reconstructions based on different molecular genetic markers could not clarify the phylogenetic position of Presbytis. Mobile elements indicate a close relationship to the odd-nosed group, nuclear sequence data show a basal position among the Asian colobines and mitochondrial sequence data placed Presbytis as sister to Trachypithecus.

- Does the colobine monkey phylogeny support a possible hybridization between Presbytis and Trachypithecus or between Semnopithecus and Trachypithecus (Ting et al. 2008)?

Our results do not support an ancient hybridization between Presbytis and Trachypithecus. Nuclear divergence time estimates between Semnopithecus and Trachypithecus (2.56 mya) postdate the mitochondrial divergence of Presbytis and Trachypithecus (7.45 mya). They indicate unidirectional gene flow from Semnopithecus into 
Trachypithecus via male introgression over a long period of time, which finally led to the accumulation of nuclear material of Semnopithecus into Trachypithecus (nuclear swamping).

\section{Are previous classifications of Presbytis supported by new data from the} field?

- Is P.comata a polytypitc species group (Brandon-Jones 1978, 1996c)?

Our genetic results show an early separation of P.thomasi and P.hosei and a late differentiation of P.comata. The structural analysis of loud-calls also clearly separates P.thomasi and P.comata. Therefore, and in accordance with Groves (2001), P.hosei, P.thomasi, and P.comata should be regarded as distinct species.

- Is P.melalophos a polytypic species group (Md Zain 2001)?

According to our genetic results the South Sumatran P. m. mitrata forms a sister lineage to P.comata and the Central Sumatran P.m.mitrata population is placed in the P.melalophos clade. Therefore P.melalophos is paraphyletic. Furthermore close phylogenetic affiliations between P.melalophos and P.femoralis could not be detected, since both taxa derive from clearly distinct lineages. Acoustic differences in call structure strongly support the paraphyly of P.melalophos. As a consequence, our results indicate a further differentiation of P.melalophos rather than a polytypic species proposed by Md Zain (2001). In agreement with the Phylogenetic Species Concept (Cracraft 1983, 1989), a revision of the current classification is appropriate and P.m.mitrata should be regarded as distinct species P.mitrata (Eschscholtz 1821).

- Is there a conspecific relationship between P.potenziani and P.thomasi (Wilson and Wilson 1976)?

Our genetic results do not support a conspecific relationship of P.potenziani and P.thomasi. Instead our results show a basal position of P.thomasi, which separated from all other Presbytis taxa in the late Miocene around 6.7 mya. P.potenziani is nested within Presbytis and derived much later in the late Pliocene (2.6 mya) from the P.melalophos/P.comata/P.rubicunda clade. The acoustic structure of P.thomasi and 
P.potenziani calls is signaficantly distinct, although however, both call types share coughing inhalation and exhalation elements and a tonal howling ending phrase. This particular call structure is more likely pleisiomorphic rather than a product of a convergent evolution.

3. Can existing phylogeographic hypothesis of Presbytis be supported by divergence time estimates and a reassessed phylogeny of the genus?

- When did the genus Presbytis evolve?

Our divergence time estimates of Presbytis suggest that the genus originated during the late Miocene between 5.88 mya (chapter 2) and 14.09 mya (chapter 3), which is in a similar range as previous estimates (Chatterjee et al. 2009; Raaum et al. 2005; Sterner et al. 2006). It is important to note, that results obtained of such an analysis remain a design approach and often differ in various studies. Beside the algorithms used for the estimation and the choice of calibration points (e.g. Drummond et al. 2006; Knoop and Müller 2009; Sanderson 2002, 2003), the total length of the analyzed sequences and the sample size could influence the results. The latter could have biased the results of our divergence time estimation between Presbytis and Trachypithecus (whole mitochondrial genome and a small sample size: 5.88 mya - 8.86 mya; only cytochrome b and a large sample size: 9.01 mya - 14.09 mya).

- Do our results support an east/west or a west/east dispersal pattern of Presbytis?

Since previous models based on a basal position of either P.potenziani from the Mentawai Islands (Brandon-Jones 1978; Brandon-Jones 1996a; Meijaard and Groves 2004) or P.hosei from North Borneo (Md Zain 2001), our results indicate a different pattern. As mentioned above P.thomasi split from an ancestral form first around 6.7 mya. During this period of time the Asian mainland, Borneo and Sumatra were possibly still connected (Meijaard 2004). Shortly afterwards the Bornean and the Malayan Presbytis lineages differentiated between 6.1 mya and 5.3 mya. Accordingly P.thomasi might have evolved on the Asian mainland and could have subsequently been isolated 
to North Sumatra, at the time when Sumatra became disconnected from Malaya due to rising sea-levels (Miller et al. 2005) during the later Miocene or early/middle Pliocene (Meijaard 2004).

Our phylogenetic reconstruction furthermore indicates that some anatomical features, which led to the assumption of a basal position of P.potenziani (Brandon-Jones 1978; Brandon-Jones 1996a) are pleisiomorphic. The ancestors of P.potenziani were possibly outcompeted and continuously displaced by other Presbytis following a route towards Sumatra. Proto-potenziani migrated to Sumatra via a landbridge that most likey existed during most of the Pliocene (Meijaard 2004). A further landbridge between the Mentawai Islands and Sumatra, which possibly emerged during a major glacial in the late Pleistocene (Ziegler et al. 2007), enabled proto-potenziani to finaly colonize the Mentawai Islands between 3.4 mya and 1.9 mya. The colonization of the Mentawai Islands by macaques (Roos et al. 2003; Ziegler et al. 2007) and gibbons (Thinh et al. 2010a) during a comparible period of time, also supports the existence of a landbride. The particular climate of the Menatwai islands enabled the archipelago to sustain a requisite habitat, which was almost everywhere else affected by severe glaciations and changed dramatically (Brandon-Jones 1993). Even during the last glacial maximum the Mentawai Islands were most likely one of the only remaining stable rain forest refugias in Sundaland (Brandon-Jones 1998; Gathorne-Hardy et al. 2002).

- Are there any explanations for Presbytis allopatry on Sumatra and sympatry on Borneo?

According to our phylogenetic reconstruction P.rubicunda is nested in the P.melalophos clade. P.rubicunda split sometimes during the early/middle Pleistocene and invaded Borneo, which was already colonized by $P$. chrysomelas, $P$. frontata and $P$. hosei. Today, P. rubicunda is sympatric with the three other Bornean species wherever their ranges overlap (Nijman, 2010). But with our results we can not explain why $P$. chrysomelas, $P$. frontata and $P$. hosei also occur sympatrically. The reason therefore is proposed to be related to present day ecology (Meijaard and Groves 2004). The soils of Bornean inland areas are generally very poor and low in nutrients (Davies and Baillie 
1988) and dipterocarp trees dominate the plant composition (Bennett and Davies 1994). Dipterocarps provide little food for herbivorous mammals, including Colobines (Bennett and Davies 1994). Thus the Bornean species had to specialize to narrow feeding niches. Accordingly, the sympatric representatives on Borneo also stand for ecological distinct groups. On Sumatra, on the other hand, there is ecological scope for only a single folivore-granivore specialist. Accordingly there is considerable competition for the same resources, and therefore species tend to remain allopatric (Meijaard and Groves 2004).

\subsection{Consideration of the major results}

The present genetic study regarding the genus Presbytis is based on mitochondrial DNA (mtDNA) sequence data. MtDNA functions as a single locus (Funk and Omland 2003) and sorting failure of ancestral polymorphisms (incomplete lineage sorting (ILS)) could lead to phylogenetic reconstructions that do not reflect the "true" phylogeny. Because the mitochondrial genome is haploid and only maternally inherited, stochastically lineage sorting is expected to progress more rapidly for mitochondrial alleles than for nuclear allels (Avise 2004; Funk and Omland 2003). Sorting failures due to ILS however could not be ruled out completely (Funk and Omland 2003). Thus the detected paraphyly of P.melalophos could be also explained by ILS. Otherwise our acoustic data strongly support our findings and consequently the effect of ILS is unlikely. Another explanation for the detected paraphyly would be hybridization between P.m.melalophos and P.m.mitrata. This is likely, since both taxa meet on their distribution limit south of the Batang Hari River. To address hybridization the analysis of nuclear markers is mandatory.

In general, we have shown that mtDNA constitutes a useful marker for accurate identification of Presbytis taxa. Furthermore, in our study we were also able to confirm Way Kambas as the origin of the P.m.mitrata sample from the Ragunan Zoo. Therefore the analysis of mtDNA is being also suitable for conservation issues in terms of locating 
hunting spots, indentifying the origin of confiscated animals or selecting individuals for captive breeding programs.

In particular hybridization has been increasingly considered as an important factor in the evolution of species (Arnold and Meyer 2006) and many recent studies in primates uncovered various examples. For instance hybridization was reported in macaques (e.g. Kanthaswamy et al. 2008), baboons (e.g. Alberts and Altmann 2001; Keller et al. 2010; Zinner et al. 2009b), between baboons and geladas (Jolly et al. 1997) and between gray langurs (Semnopithecus) and Lutungs (Trachypithecus) (Hohmann 1988). The latter study used vocalizations to address the hybridization between both taxa. According to Hohmann (1988) hybrids produce calls which contain species-specific patterns of both, Semnopithecus entellus and Trachypithecus johnii. Similar results were also obtained in guenons (Gautier and Gautier 1977) and gibbons (Brockelman 1978; Geissmann 1993; Tenaza 1985). On the contrary it is also reported that hybrids could show acoustic traits of either one of their parents. In that case the hybrid exclusively had the morphological characteristics of exactly that parent (Hohmann 1988; Newman and Symmes 1982). Thus, in the case of the central Sumatran P.m.mitrata, which has more the morphological appearance of P.m.melalophos and its specific call structure, hybridization might still be possible.

However, our study demonstrates that the analysis of acoustic traits is a powerful tool, particularly if acoustic data of respective populations can be directly combined with their genetic information. Various recent acoustic studies used vocal differences to distinguish species, for instance in crickets (Shaw 2000), frogs (Stuart et al. 2011), treeshrews (Esser et al. 2008) and also in other primates i.e. tarsius (Burton and Nietsch 2010). Our study sets itself apart from these studies, because our comparative approach enabled us to address migration backgrounds as well, while we could also distinguish between Presbytis species. Such an analysis could therefore also be applied to other animals, where pronounced mating and/or territorial behavior indicate high selective pressure. For instance, it could be a promsing tool to uncover the complex evolution of baboons (Zinner et al. 2009b). 
Besides the scientific interest to understand phylogentic patterns or mechanisms of speciation, such studies have also conservational implications. For the evaluation of the conservation status of respective taxa, it is crucial to know the taxonomic status and the phylogenetic relationship between different populations to identify them as targets for conservation (Weisrock et al. 2010). In Presbytis the population trend in almost all taxa is decreasing, mostly due to habitat destruction, but also due to hunting and pet trade (IUCN 2010). For instance at least $80 \%$ of the natural forest habitat of P.m.mitrata has been removed since the colonial time, and at least $50 \%$ of this has occurred in the past 30 years (FWI/GFW 2002). Today the remaining forests are severely fragmented (IUCN 2010) and this leads to limited gene flow between populations and could also finally lead to extinction.

\subsection{Outlook}

1. To understand the phylogeny and phylogeography of the genus all described taxa should be addressed. Therefore complete mitochondrial genome sequences should be generated and used in the analysis, which could increase the resolution of unresolved polytomies (this could refer to the Bornean lineage and the P.melalophos group).

2. Assessment of the taxonomic status of the Bornean and Malayan taxa and the Sumatran taxa P.f.percura, P.s.cana and P.s.paenulata.

3. Broader sampling of P.m.melalophos and the generation of nuclear sequence data to address possible hybridization between P.m.mitrata and P.m.melalophos.

4. Assessment of the taxonomic status of P.rubicunda. If the species status of P.rubicunda would be confirmed, consequently the species status of P.m.sumatrana, P.m.bicolor and P.m.melalophos would be warranted. Otherwise P.rubicunda has to be assigned as a subspecies of P.melalophos. 


\section{References}

Aimi, M. \& Bakar, A. 1992. Taxonomy and distribution of Presbytis melalophos group in Sumatera, Indonesia. Primates, 33, 191-206.

Aimi, M. \& Bakar, A. 1996. Distribution and deployment of Presbytis melalophos group in Sumatera, Indonesia. Primates, 37, 399-409.

Alberts, S. C. \& Altmann, J. 2001. Immigration and hybridization patterns of yellow and anubis baboons in and around Amboseli, Kenya. American Journal of Primatology, 53, 139-154.

Arnold, M. L. \& Meyer, A. 2006. Natural hybridization in primates: one evolutionary mechanism. Zoology, 109, 261 - 276.

Avise, J. C. 2004. Molecular markers, natural history, and evolution. Sunderland (Massachusetts): Sinauer Associates.

Barry, J. C., Johnson, N. M., Raza, S. M. \& Jacobs, L. L. 1985. Neogene mammalian faunal change in southern Asia: correlations with climatic, tectonic, and eustatic events. Geology, 13, 637.

Barton, N. H. 2001. The role of hybridization on evolution. Molecular Evolution, 10, 551 - 568.

Batzer, M. A. \& Deininger, P. L. 1991. A human-specific subfamily of Alu sequences. Genomics, 9, 481 - 487.

Benefit, B. R. \& McCrossin, M. L. 2002. The Victoriapithecidae, Cercopithecoidea. In: The Primate Fossil Record (Ed. by Hartwig, W. C.), pp. 241 - 253: Cambridge University Press.

Bennett, E. L. \& Davies, A. G. 1994. The ecology of Asian colobines. Colobine monkeys: their ecology, behaviour and evolution, 129-171.

Brainard, M. S. \& Doupe, A. J. 2002. What songbirds teach us about learning. Nature, 417, 351-358.

Brandon-Jones, D. 1978. The evolution of recent Asian colobines. In: Recent Advances in Primatology (Ed. by Chivers, D. J. \& Joysey, K. A.), pp. 323-325. London: Academic Press London.

Brandon-Jones, D. 1984. Colobus and leaf monkeys. In: Encylopedia of Mammals, pp. 398 - 408.

Brandon-Jones, D. 1993. Taxonomic affinities of the Menatwai islands surili (Bonaparte, 1856), P. potenziani. Raffles Bulletin of Zoology, 41, 331 - 357.

Brandon-Jones, D. 1995. Presbytis fredericae (Sody, 1930), an endangered colobine species endemic to central Java, Indonesia. Primate Conservation, 16, 68-70.

Brandon-Jones, D. 1996a. The Asian Colobinae (Mammalia: Cercopithecidae) as indicators of Quaternary climatic change. Biological Journal of the Linnean Society, 59, 327350.

Brandon-Jones, D. 1996b. Presbytis species sympatry in Borneo versus allopatry in Sumatra: an interpretation. In: Tropical Rainforest - Current Issues (Ed. by Edwards, D. S., Booth, W. E. \& Choy, C.), pp. 71-76: Kluwer Academic Publishers. 
Brandon-Jones, D. 1996c. The zoogeography of sexual dichromatism in the Bornean grizzled surili. Presbytis comata (Desmarest, 1822). Sarawak Museum Journal, 5, 177 200.

Brandon-Jones, D. 1998. Pre-glacial Bornean primate impoverishment and Wallace's line. Biogeography and geological evolution of SE Asia, 393-404.

Brandon-Jones, D. 2004. A taxonomic revision of the langurs and leaf monkeys (Primates: Colobinae) of South Asia. Zoos' Print Journal, 19, 1552-1594.

Brandon-Jones, D., Eudey, A. A., Geissmann, T., Groves, C. P., Melnick, D. J., Morales, J. C., Shekelle, M. \& Stewart, C. B. 2004. Asian primate classification. International Journal of Primatology, 25, 97 - 164.

Brockelman, W. Y. 1978. Preliminary report on relations between the gibbons Hylobates lar and H.pileatus in Thailand. In: Recent Advances in Primatology (Ed. by Chivers, D. J. \& Joysey, K. A.), pp. 315-318. London: Academic Press London.

Brockelman, W. Y. \& Ali, R. 1987. Methods of surveying and sampling forest primate populations. In: Primate Conservation in the Tropical Rain Forest (Ed. by Marsh, C. W. \& Mittermeier, R. A.), pp. 23 - 62. New York: Alan R. Liss.

Brunet, M., Guy, F., Pilbeam, D., Lieberman, D. E., Likius, A., Mackaye, H. T., Ponce de Leon, M. S., Zollikofer, C. P. \& Vignaud, P. 2005. New material of the earliest hominid from the upper Miocene of Chad. Nature, 434, 752 - 755.

Brunet, M., Guy, F., Pilbeam, D., Mackaye, H. T., Likius, A., Ahounta, D., Beauvilain, A., Blondel, C., Bocherens, H. \& Boisserie, J. R. 2002. A new hominid from the Upper Miocene of Chad, Central Africa. Nature, 418, 145-151.

Burnham, K. P. \& Anderson, D. R. 2002. Model selection and multimodel inference: a practical information-theoretic approach. New York: Springer Verlag.

Burton, J. A. \& Nietsch, A. 2010. Geographical variation in duet songs of Sulawesi tarsiers: Evidence for new cryptic species in south and southeast Sulawesi. International Journal of Primatology, 1-24.

Castresana, J. 2000. Selection of conserved blocks from multiple alignments for their use in phylogenetic analysis. Molecular Biology and Evolution, 17, 540 - 552.

Cerling, T. E., Harris, J. M., MacFadden, B. J., Leakey, M. G., Quade, J., Eisenmann, V. \& Ehleringer, J. R. 1997. Global vegetation change through the Miocene/Pliocene boundary. Nature, 389, 153-158.

Chakraborty, D., Ramakrishnan, U., Panor, J., Mishra, C. \& Sinha, A. 2007. Phylogenetic relationships and morphometric affinities of the Arunachal macaque Macaca munzala, a newly described primate from Arunachal Pradesh, northeastern India. Molecular Phylogenetics and Evolution, 44, 838 - 849.

Chasen, F. N. 1940. A handlist of Malaysian mammals (A systematic list of the mammals of the Malay Peninsula, Sumatra, Borneo and Java, including the adjacent small islands). Bulletin of the Raffles Museum., 15, 1-209.

Chatterjee, H. J., Ho, S. Y. W., Barnes, I. \& Groves, C. 2009. Estimating the phylogeny and divergence times of primates using a supermatrix approach. BMC Evolutionary Biology, 9, 259.

Chaves, R., Sampaio, I., Schneider, M. P., Schneider, H., Page, S. L. \& Goodman, M. 1999. The place of Callimico goeldii in the callithrichine phylogenetic tree: evidence 
from von Willebrand factor gene intron 11 sequences. Molecular Phylogenetics and Evolution, 13, 392 - 404.

Chivers, D. J. 1994. Functional anatomy of the gastrointestinal tract. In: Colobine monkeys - their ecology, behaviour and evolution (Ed. by Davies, A. G. \& Oates, J. F.), pp. 205 - 227. Cambridge: Cambridge University Press.

Clutton Brock, T. H. \& Harvey, P. H. 1977. Primate ecology and social organization. Journal of Zoology, 183, 1-39.

Corbet, G. B. \& Hill, J. E. 1992. The mammals of the Indomalayan region (Ed. Natural History Museum Publications), Oxford:University Press.

Cortes-Ortiz, L., Duda, T. F., Canales-Espinosa, D., Garcia-Orduna, F., Rodriguez-Luna, E. \& Bermingham, E. 2007. Hybridization in large-bodied New World primates. Genetics, 176, $2421-2425$.

Cracraft, J. 1983. Species concepts and speciation analysis. Current ornithology, 1, 159187.

Cracraft, J. 1989. Speciation and its ontology: the empirical consequences of alternative species concepts for understanding patterns and processes of differentiation. Speciation and its Consequences, 28-59.

Craul, M., Zimmermann, E., Rasoloharijaona, S., Randrianambinina, B. \& Radespiel, U. 2007. Unexpected species diversity of Malagasy primates (Lepilemur spp.) in the same biogeographical zone: a morphological and molecular approach with the description of two new species. BMC Evolutionary Biology, 7, 83.

Da Cunha, R. G. T. \& Byrne, R. W. 2006. Roars of black howler monkeys (Alouatta caraya): evidence for a function in inter-group spacing. Behaviour, 143, 1169-1199. Darwin, C. 1859. On the origin of species by means of natural selection, or the preservation of favoured races in the struggle for life (Ed. Murray, J.) London.

Davies, A. G. \& Baillie, I. C. 1988. Soil-eating by red leaf monkeys (Presbytis rubicunda) in Sabah, Northern Borneo. Biotropica, 252-258.

Davies, A. G. \& Oates, A. S. 1994. Preface. In: Colobine monkeys: their ecology, behaviour and evolution (Ed. by Davies, A. G. \& Oates, A. S.), pp. xi - xiii. Cambridge: University Press.

De Queiroz, K. 2005. Ernst Mayr and the modern concept of species. Proceedings of the National Academy of Sciences of the United States of America, 102, 6600.

De Queiroz, K. 2007. Species concepts and species delimitation. Systematic Biology, $56,879$.

Delson, E. 1994. Evolutionary history of the colobine monkey $s$ in paleoenvironmental perspective. In: Colobine monkeys: their ecology, behaviour and evolution (Ed. by Oates, J. F., Davies, A. G. \& Delson, E.), pp. 11 - 43. Cambridge: University Press. Delson, E. 2000. Cercopithecinae. Encyclopedia of Human Evolution and Prehistory, $166-171$.

Delson, E., Groves, C. P., Grubb, P., Miu, C. A. \& Wang, S. 1982. Family Cercopithecidae. In: Mammal Species of the World (Ed. by Honacki, J. H. \& Kinman, K. E.), pp. 230 242. Lawrence, KS: Association of Systematics Collections.

Drummond, A. J., Ho, S. Y. W., Phillips, M. J. \& Rambaut, A. 2006. Relaxed phylogenetics and dating with confidence. PLoS Biology, 4, e88. 
Drummond, A. J., Kearse, M., Heled, J., Moir, R., Thierer, T., Ashton, B., Wilson, A. \& Stones-Havas, S. 2008. Geneious, version 4.6.1.

Drummond, A. J. \& Rambaut, A. 2007. BEAST: Bayesian evolutionary analysis by sampling trees. BMC Evol Biol, 7, e214.

Eschscholtz, F. 1821. A new species of monkey (Presbytis mitrata). In: Voyage of discovery in the South Seas, and to Behring Straits: in search of a north-east passage, undertaken in the years 1815, 16, 17, and 18, in the ship Rurick (Ed. by Von Kotzebue, O.), pp. 353 - 356: Printed for Sir Richard Phillips and Co.

Esser, D., Schehka, S. \& Zimmermann, E. 2008. Species-specificity in communication calls of tree shrews (Tupaia: Scandentia). Journal of Mammalogy, 89, 1456-1463.

Ey, E. \& Fischer, J. 2009. The" Acoustic Adaptation Hypothesis"-a review of the evidence from birds, anurans and mammals. Bioacoustics the International Journal of Animal Sound and Its Recording, 19, 21-48.

Felsenstein, J.: PHYLIP (Phylogenetic Inference Package) version 3.69, Department of Genome Science, University of Washington, Seattle, USA.

$<h t t p: / / e v o l u t i o n . g e n e t i c s$. washington.edu/phylip/getme.htm/>

Fleagle, J. G. 1977. Locomotor behavior and muscular anatomy of sympatric Malaysian leaf monkeys (Presbytis obscura and Presbytis melalophos). American journal of physical anthropology, 46, 297-307.

Funk, D. J. \& Omland, K. E. 2003. Species-level paraphyly and polyphyly: frequency, causes, and consequences, with insights from animal mitochondrial DNA. Annual Review of Ecology, Evolution, and Systematics, 397-423.

FWI/GFW. 2002. The state of the forest: Indonesia. In: Forest Watch Indonesia and Global Forest Watch, $<$ ttp://www.globalforestwatch.org/common/indonesia/sof.indonesia.english.low.pdf $>$. Washington DC, USA.

Gathorne-Hardy, F. J., Syaukani, Davies, R. G., Eggleton, P. \& Jones, D. T. 2002. Quaternary rainforest refugia in south-east Asia: using termites (Isoptera) as indicators. Biological Journal of the Linnean Society, 75, 453-466.

Gautier, J. P. \& Gautier, A. 1977. Communication in old world monkeys. In: How animals communicate (Ed. by Sebeok, T. A.), pp. 890-964. Bloomington: Indiana University Press.

Geissmann, T. 1993. Evolution of communication in gibbons (Hylobatidae), Universität Zürich, Zürich, Thesis.

Geissmann, T. 2000. Gibbon songs and human music from an evolutionary perspective. In: The origins of music (Ed. by Wallin, N. L., Merker, S. \& Brown, S.), pp. 103-123. Massachusetts: Massachusetts Institut of Technology.

Geissmann, T. 2002. Taxonomy and evolution of gibbons. Anthropology and Primatology into the Third Millennium, 28 - 31.

Geissmann, T. \& Nijman, V. 2006. Calling in wild silvery gibbons (Hylobates moloch) in Java (Indonesia): behavior, phylogeny, and conservation. American Journal of Primatology, 68, 1-19.

Gelman, A. \& Rubin, D. B. 1992. Inference from iterative simulation using multiple sequences. Statistical science, 457-472. 
Goodman, M., Porter, C. A., Czelusniak, J., Page, S. L., Schneider, H., Shoshani, J., Gunnell, G. \& Groves, C. P. 1998. Toward a phylogenetic classification of primates based on DNA evidence complemented by fossil evidence. Molecular Phylogenetics and Evolution, 9, 585 - 598.

Green, R. E., Krause, J., Briggs, A. W., Maricic, T., Stenzel, U., Kircher, M., Patterson, N., Li, H., Zhai, W., Fritz, M. H., Hansen, N. F., Durand, E. Y., Malaspinas, A. S., Jensen, J. D., Marques-Bonet, T., Alkan, C., Prufer, K., Meyer, M., Burbano, H. A., Good, J. M., Schultz, R., Aximu-Petri, A., Butthof, A., Hober, B., Hoffner, B., Siegemund, M., Weihmann, A., Nusbaum, C., Lander, E. S., Russ, C., Novod, N., Affourtit, J., Egholm, M., Verna, C., Rudan, P., Brajkovic, D., Kucan, Z., Gusic, I., Doronichev, V. B., Golovanova, L. V., Lalueza-Fox, C., de la Rasilla, M., Fortea, J., Rosas, A., Schmitz, R. W., Johnson, P. L., Eichler, E. E., Falush, D., Birney, E., Mullikin, J. C., Slatkin, M., Nielsen, R., Kelso, J., Lachmann, M., Reich, D. \& Paabo, S. A draft sequence of the Neandertal genome. Science, 328, 710 - 722.

Groeneveld, L. F. 2008. Species delimitation, phylogeography and population genetics of the endemic Malagasy dwarf lemurs (genus Cheirogaleus), Georg-AugustUniversität.

Groves, C. P. 1970. The forgotten leaf-eaters, and the phylogeny of the Colobinae. In Old world monkeys: Evolution, Systematics and Behavior (Ed. Napier, J. R. \& Napier P. H.): New York: Academic Press, 555-588.

Groves, C. P. 1989. A theory of human and primate evolution: Clarendon Press.

Groves, C. P. 2001. Primate Taxonomy: Washington: Smithsonian Institution Press. Groves, C. P. 2004. The What, Why and How of Primate Taxonomy. International Journal of Primatology, 25, 1105-1126.

Gurmaya, K. 1986. Ecology and behavior of Presbytis thomasi in Northern Sumatra. Primates, 27, 151-172.

Hallet, B. \& Molnar, P. 2001. Distorted drainage basins as markers of crustal strain east of the Himalayas. Journal of Geophysical Research, 106, 13697 - 13709.

Haq, B. U., Hardenbol, J. A. N. \& Vail, P. R. 1987. Chronology of Fluctuating Sea Levels Since the Triassic. Science, 235, 1156-1167.

Hellborg, L. \& Ellegren, H. 2003. Y chromsome conserved anchored tagged sequences (YCATS) for the analysis of mammalian male-specific DNA. Molecular Evolution, 12, 283 - 291.

Herke, S. W., Xing, J., Ray, D. A., Zimmermann, J. W., Cordaux, R. \& Batzer, M. A. 2007. A SINE-based dichotomous key for primate identification. Gene, 390, 39 - 51. Hershkovitz, P. 1968. Metachromism or the principle of evolutionary change in mammalian tegumentary colors. Evolution, 556-575.

Hofreiter, M., Siedel, H., Van Neer, W. \& Vigilant, L. 2003. Mitochondrial DNA sequence from an enigmatic gorilla population (Gorilla gorilla uellensis). American Journal of Physical Anthropology, 121, 361 - 368.

Hohmann, G. 1988. Analysis of loud calls provides new evidence for hybridization between two Asian leaf monkeys (Presbytis johnii, Presbytis entellus). Folia Primatologica, 51, 209-213. 
Hooijer, D. A. 1962. Quaternary langurs and macaques from the Malay Archipelago. Zoologische verhandelingen, 55, 1-64.

Huelsenbeck, J. P., Ronquist, F., Nielsen, R. \& Bollback, J. P. 2001. Bayesian inference of phylogeny and its impact on evolutionary biology. Science, 294, 2310 - 2314.

IUCN. 2010. 2010. IUCN Red List of Threatened Species. Version 2010.1.

http://www.iucnredlist.org.

Jablonski, N. G. 1998. The natural history of the doucs and snub-nosed monkeys: World Scientific Pub Co Inc.

Jablonski, N. G., Zhang, Y.-p., Ryder, O. A., Stewart, C.-B. \& Disotell, T. R. 1999. Primate evolution -- in and out of Africa. Current Biology, 9, R119-R122.

Jolly, C. J., Woolley-Barker, T., Beyene, S., Disotell, T. R. \& Phillips-Conroy, J. E. 1997. Intergeneric hybrid baboons. International Journal of Primatology, 18, 597-627.

Kanthaswamy, S., Satkoski, J., George, D., Kou, A., Erickson, B. J. A. \& Smith, D. G. 2008. Interspecies hybridization and the stratification of nuclear genetic variation of rhesus (Macaca mulatta) and long-tailed macaques (Macaca fascicularis). International Journal of Primatology, 29, 1295.

Karanth, K. P., Singh, L., Collura, R. V. \& Stewart, C. B. 2008. Molecular phylogeny and biogeography of langurs and leaf monkeys of South Asia (Primates: Colobinae). Molecular Phylogenetics and Evololution, 46, 683 - 694.

Katoh, K., Kuma, K., Toh, H. \& Miyata, T. 2005. MAFFT version 5: improvement in accuracy of multiple sequence alignment. Nucleic Acids Research, 33, 511 - 518.

Kawamura, S. 1984. Distribution and vocalisation of Presbytis melalophos and $P$. femoralis societies in Westcentral Sumatra - a summarised report. Kyoto Univ Overseas Research Report Studies: Asian Non-human Primates , 3:37-44.

Keller, C., Roos, C., Groeneveld, L. F., Fischer, J. \& Zinner, D. 2010. Introgressive hybridization in southern African baboons shapes patterns of mtDNA variation. American journal of physical anthropology, 142, 125-136.

Kelley, J. 2002. The hominoid radiation in Asia. The Primate Fossil Record, 369 - 384.

Kishino, H. \& Hasegawa, M. 1989. Evaluation of the maximum likelihood estimate of the evolutionary tree topologies from DNA sequence data, and the branching order in Hominoidea. J Mol Evol, 29, 170 - 179.

Knoop, V. \& Müller, K. 2009. Gene und Stammbäume. München: Elsevier GmbH. Koblmüller, S., Duftner, N., Sefc, K. M., Aibara, M., Stipacek, M., Blanc, M., Egger, B. \& Sturmbauer, C. 2007. Reticulate phylogeny of gastropod-shell-breeding cichlids from Lake Tanganyika - the result of repeated introgressive hybridization. BMC Evololutionary Biology, 7, 7.

Kubatko, L. S. 2009. Identifying hybridization events in the presence of coalescence via model selection. Syst Biol, 58, 478 - 488.

Kubatko, L. S., Carstens, B. C. \& Knowles, L. L. 2009. STEM: species tree estimation using maximum likelihood for gene trees under coalescence. Bioinformatics, 25, 971 973.

Lawlor, T. E. 1969. The principle of metachromism: A critique. Evolution, 23, 509-512. 
Leakey, M. G. 1993. Evolution of Theropithecus in the Turkana Basin. In: Theropithecus, the Rise and Fall of a Primate Genus (Ed. Jablonsky, N.G.), pp. 85 - 124, Cambridge: University Press.

Lebatard, A. E., Bourles, D. L., Duringer, P., Jolivet, M., Braucher, R., Carcaillet, J., Schuster, M., Arnaud, N., Monie, P., Lihoreau, F., Likius, A., Mackaye, H. T., Vignaud, P. \& Brunet, M. 2008. Cosmogenic nuclide dating of Sahelanthropus tchadensis and Australopithecus bahrelghazali: Mio-Pliocene hominids from Chad. PnaS USA, 105, $3226-3231$.

Li, J., Han, K., Xing, J., Kim, H. S., Rogers, J., Ryder, O. A., Disotell, T., Yue, B. \& Batzer, M. A. 2009. Phylogeny of macaques (Cercopithecidae: Macaca) based on Alu elements. Gene, 448, 242 - 249.

Louis Jr., E. E., Engberg, S. E., McGuire, S. M., McCormick, M. J., Randriamampionona, R., Ranaivoarisoa, J. F., Bailey, C. A., Mittermeier, R. A. \& Lei, R. 2008. Revision of the mouse lemurs, Microcebus (Primates, Lemuriformes), of northern and northwestern Madagascar with descriptions of two new species at Montagne d'Ambre National Park and Antafondro Classified Forest. Primate Conservation, 23, 19-38.

Lucas, P. W. \& Teaford, M. F. 1994. Functional morophology of colobine teeth In: Colobine monkeys: their ecology, behaviour and evolution (Ed. by Davies, A. G. \& Oates, A. S.), pp. 173 - 203. Cambridge: University Press.

Maddison, W. P. \& Maddison, D. R. 2009. Mesquite: a modular system for evolutionary analysis, version 2.6.

Matauschek, C., Roos, C. \& Heymann, E. W. 2011. Mitochondrial phylogeny of tamarins (Saguinus, Hoffmannsegg 1807) with taxonomic and biogeographic implications for the S. nigricollis species group. American journal of physical anthropology, 144, 564-574.

Mayr, E. 1963. Animal species and evolution. Animal species and their evolution. McCracken, K. \& Sorenson, M. 2005. Is homoplasy or lineage sorting the source of incongruent mtDNA and nuclear gene trees in the stiff-tailed ducks (NomonyxOxyyura)? Systematic Biology, 54, 35 - 55.

Md Zain, B. M. 2001. Molecular systematics of the genus Presbytis, Columbia University.

Md Zain, B. M., Hasan, M. H. \& Melnick, D. J. 2002. Defining Evolutionary Significant Units For Presbytis melalophos Conservation Using Mitochondrial DNA Sequences. In: Proceedings of the Regional Symposium on Environment and Natural Resources (Ed. by Omar, R., Ali Rahaman, Z., Latif, M. T., Lihan, T. \& Adam, J. H.), pp. 279 - 286. Hotel Renaissance Kuala Lumpur Malaysia.

Md-Zain B. M., Morales J.C., Hassan M. N., Jasmi A, Lakim M., Supriatna J., Melnick D. J. 2008: Is Presbytis a distinct monophyletic genus: Inferences from mitochondrial DNA sequences. Asian Primates Journal, 1:26-36.

Medway, L. 1970. The monkeys of Sundaland: ecology and systematics of the cercopithecids of a humid equatorial environment. In: Old World monkeys: evolution, systematics, and behavior (Ed. by Napier, J. R. \& Napier, P. H.), pp. 513-553. London: Academic Press. 
Megantara, E. N. 1989. Ecology, behavior and sociality of Presbytis femoralis in eastcentral Sumatra (Eds. Ehara, A. \& Kawamura, S.), Comparative primatology monographs vol. 2 (pp. 171-301). Kyoto.

Meijaard, E. 2004. Solving mammalian riddles. A reconstruction of the Tertiary and Quaternary distribution of mammals and their palaeoenvironments in island SouthEast Asia, The Australian National University, Canberra, Thesis.

Meijaard, E. \& Groves, C. P. 2004. The Biogeographical Evolution and Phylogeny of the Genus Presbytis. Primate Report, 68, 71 - 90.

Meijaard, E. \& Groves, C. P. 2006. The geography of mammals and rivers in mainland Southeast Asia. In: Primate Biogeography (Ed. by Lehman, S. M. \& Fleagle, J. G.), pp. 305 - 329. New York: Springer Sience + Business Media, LCC.

Méndez-Cárdenas, M., Randrianambinina, B., Rabesandratana, A., Rasoloharijaona, S. \& Zimmermann, E. 2008. Geographic variation in loud calls of sportive lemurs (Lepilemur ssp.) and their implications for conservation. American Journal of Primatology, 70, 828-838.

Merker, S., Driller, C., Perwitasari-Farajallah, D., Pamungkas, J. \& Zischler, H. 2009. Elucidating geological and biological processes underlying the diversification of Sulawesi tarsiers. Proc Natl Acad Sci USA, 106, 8459 - 8464.

Meulman, J. J. \& Heiser, W. J. 1989. IBM SPSS Categories 19.

Meyer, D., Rinaldi, I. D., Ramlee, H., Perwitasari-Farajallah, D., Hodges, J. K. \& Roos, C. 2011. Mitochondrial phylogeny of leaf monkeys (genus Presbytis, Eschscholtz, 1821) with implications for taxonomy and conservation. Molecular Phylogenetics and Evolution, 59, 311-319.

Miller, K. G., Kominz, M. A., Browning, J. V., Wright, J. D., Mountain, G. S., Katz, M. E., Sugarman, P. J., Cramer, B. S., Christie-Blick, N. \& Pekar, S. F. 2005. The phanerozoic record of global sea-level change. Science, 310, 1293 - 1298.

Mitani, J. C., Hunley, K. L. \& Murdoch, M. E. 1999. Geographic variation in the calls of wild chimpanzees: A reassessment. American Journal of Primatology, 47, 133-151.

Mittermeier, R. A., Wallis, J., Rylands, A. B., Ganzhorn, J. U., Oates, J. F., Williamson, E. A., Palacios, E., Heymann, E. W., Kierulff, M. C. M. \& Yongcheng, L. 2009. Primates in Peril: The World's 25 Most Endangered Primates 2008-2010. Primate Conservation, 24, 2-4.

Moritz, C. 1994. Defining'evolutionarily significant units' for conservation. Trends in ecology and evolution, 9, 373-374.

Napier, J. R. \& Napier, P. H. 1967. A handbook of living primates: morphology, ecology and behaviour of nonhuman primates. London: Academic Press.

Napier, P. H. 1985. Catalogue of primates in the British Museum (natural history) and elsewhere in the British isles. Part III. Family cercopithecidae, subfamily colobinae Oxford: University Press.

Newman, J. D. \& Symmes, D. 1982. Inheritance and experience in the acquisition of primate acoustic behavior. In: Primate Communication (Ed. by Snowdon, C. T., Brown, C. H. \& Peterson, M. R.), pp. 259 - 278. Cambridge: Cambridge University Press. Newton, P. N. \& Dunbar, R. I. M. 1994. Colobine monkey society. Colobine monkeys: their ecology, behaviour and evolution, 311 - 346. 
Nichols, R. 2001. Gene trees and species trees are not the same. Trends in Ecology \& Evolution, 16, 358 - 364.

Nijman, V. 1997. Geographic variation in pelage characteristics in Presbytis comata (Desmarest, 1822) (Mammalia: Primates, Cercopithecidae). Zeitung für

Säugetierkunde, 62, 257 - 264.

Nijman, V. 2001. Forest (and) primates: conservation and ecology of the endemic primates of Java and Borneo, Tropenbos-Kalimantan Series 5, Thesis.

Nijman, V. 2004. Effects of habitat disturbance and hunting on the density and the biomass of the endemic Hose's leaf monkey Presbytis hosei (Thomas, 1889)(Mammalia: Primates: Cercopithecidae) in east Borneo. Contributions to Zoology, 73, 283-291.

Nijman, V. 2010. Ecology and Conservation of the Hose's Langur Group (Colobinae: Presbytis hosei, P. canicrus, P. sabana): A Review. In: Indonesian Primates (Ed. by Gursky, S. \& Supriatna, J.), pp. 269-284. New York: Springer.

Nsubuga, A. M., Robbins, M. M., Roeder, A. D., Morin, P. A., Boesch, C. \& Vigilant, L. 2004. Factors affecting the amount of genomic DNA extracted from ape faeces and the identification of an improved sample storage method. Molecular Ecology, 13, 20892094.

Oates, J. F. 1994. The natural history of African colobines. In: Colobine monkeys: their ecology, behaviour and evolution (Ed. by Oates, J. F., Davies, A. G. \& Delson, E.), pp. 75 - 128. Cambridge: University Press.

Oates, J. F. \& Davies, A. G. 1994. What are the colobines. In: Colobine monkeys: their ecology, behaviour and evolution (Ed. by Oates, J. F., Davies, A. G. \& Delson, E.), pp. 19. Cambridge: University Press.

Oates, J. F., Davies, A. G. \& Delson, E. 1994. The diversity of living colobines. In: Colobine monkeys: their ecology, behaviour and evolution (Ed. by Oates, J. F., Davies, A. G. \& Delson, E.), 45-73.

Oates, J. F. \& Trocco, T. F. 1983. Taxonomy and phylogeny of black-and-white colobus monkeys: Inferences from an analysis of loud call variation. Folia Primatologica.

Okada, N. 1991. SINEs. Current opinion in genetics and development, 1, 498 - 504.

Osterholz, M., Walter, L. \& Roos, C. 2008. Phylogenetic position of the langur genera Semnopithecus and Trachypithecus among Asian colobines, and genus affiliations of their species groups. BMC Evolutionary Biology, 8, 58.

Osterholz, M., Walter, L. \& Roos, C. 2009. Retropositional events consolidate the branching order among New World monkey genera. Molecular Phylogenetics and Evolution, 50, 507 - 513.

Pääbo, S. 2003. The mosaic that is our genome. Nature, 421, 409 - 412.

Padgham, M. 2004. Reverberation and frequency attenuation in forests-implications for acoustic communication in animals. The Journal of the Acoustical Society of America, 115, 402.

Patterson, N., Richter, D. J., Gnerre, S., Lander, E. S. \& Reich, D. 2006. Genetic evidence for complex speciation of humans and chimpanzees. Nature, 441, 1103 - 1108. 
Peakall, R. O. D. \& Smouse, P. E. 2006. GENALEX 6: genetic analysis in Excel. Population genetic software for teaching and research. In: Molecular Ecology Notes, pp. 288295.

Peng, Y. Z., Pan, R. L. \& Jablonski, N. G. 1993. Classification and evolution of Asian colobines. Folia Primatol, 60, 106 - 117.

Petit, R. J. \& Excoffier, L. 2009. Gene flow and species delimitation. Trends in Ecology and Evolution, 24, 386 - 393.

Philippe, H. \& Laurent, J. 1998. How good are deep phylogenetic trees? Current Opinion in Genetics and Development, 8, 616 - 623.

Pocock, R. I. 1928. The langurs, or leaf monkeys, of British India. Journal of the Bombay Natural History Society, 32, 472 - 504.

Pollard, D. A., Iyer, V. N., Moses, A. M. \& Eisen, M. B. 2006. Widespread discordance of gene trees with species tree in Drosophila: evidence for incomplete lineage sorting. PLoS Genetics, 2, e173.

Posada, D. 2008. jModelTest: phylogenetic model averaging. Molecular Biology and Evolution, 25, 1253.

Posada, D. \& Crandall, K. A. 1998. Modeltest: testing the model of DNA substitution. Bioinformatics, 14, 817 - 818.

Pusey, A. E. \& Packer, C. 1987. Dispersal and philopatry. In: Primate Societies (Ed. by Smuts, B. B., Cheney, D. L., Seyfarth, R. M., Wrangham, R. W. \& Struhsaker, T. T.), pp. 250 - 266. Chicago: University of Chicago Press.

Raaum, R. L., Sterner, K. N., Noviello, C. M., Stewart, C. B. \& Disotell, T. R. 2005. Catarrhine primate divergence dates estimated from complete mitochondrial genomes: concordance with fossil and nuclear DNA evidence. Journal of Human Evolution, 48, 237 - 257.

Rambaut, A. 2006. Figtree. Version 1.3. 1. Institute of Evolutionary Biology, University of Edinburgh.

Rambaut, A. 2008. FigTree: Tree figure drawing tool, version 1.2.2.

Rambaut, A. \& Drummond, A. 2005. Tracer v1. 3: MCMC trace analysis tool. Edinburgh: Univ of Edinburgh.

Rambaut, A. \& Drummond, A. J. 2007. Tracer v1.4.1: MCMC trace analysis tool. Ray, D. A., Xing, J., Hedges, D. J., Hall, M. A., Laborde, M. E., Anders, B. A., White, B. R., Stoilova, N., Fowlkes, J. D., Landry, K. E., Chemnick, L. G., Ryder, O. A. \& Batzer, M. A. 2005. Alu insertion loci and platyrrhine primate phylogeny. Molecular Phylogenetics and Evolution, 35, 117 - 126.

Ray, D. A., Xing, J., Salem, A. H. \& Batzer, M. A. 2006. SINEs of a nearly perfect character. Systematic Biology, 55, 928 - 935.

Ronquist, F. \& Huelsenbeck, J. P. 2003. MrBayes 3: Bayesian phylogenetic inference under mixed models. Bioinformatics, 19, 1572 - 1574.

Roos, C., Nadler, T. \& Walter, L. 2008. Mitochondrial phylogeny, taxonomy and biogeography of the silvered langur species group (Trachypithecus cristatus). Molecular Phylogenetics and Evolution, 47, 629-636.

Roos, C., Schmitz, J. \& Zischler, H. 2004. Primate jumping genes elucidate strepsirrhine phylogeny. Proceedings of the National Academy of Sciences USA, 101, 10650 - 10654. 
Roos, C., Ziegler, T., Keith Hodges, J., Zischler, H. \& Abegg, C. 2003. Molecular phylogeny of Mentawai macaques: taxonomic and biogeographic implications. Molecular Phylogenetics and Evolution, 29, 139-150.

Ross, M. D. \& Geissmann, T. 2007. Call diversity of wild male orangutans: a phylogenetic approach. American Journal of Primatology, 69, 305-324.

Rowe, E. B. Y. N. \& Myers, M. 2011. All The World's Primates. Charlestown RI: Primate Conservation Inc.

Rumpler, Y., Warter, S., Hauwy, M., Fausser, J. L., Roos, C. \& Zinner, D. 2008. Comparing chromosomal and mitochondrial phylogenies of sportive lemurs (genus Lepilemur, Primates). Chromosome Research, 16, 1143 - 1158.

Russell, A., Mittermeier, R. A., Louis Jr., E. E., Richardson, M., Schwitzer, C., Langrand, O., Rylands, A. B., Hawkins, F., Rajaobelina, S., Ratsimbazafy, J., Rasoloarison, R., Roos, C., Kappeler, P. M. \& Mackinnon, J. 2010. Lemurs of Madagascar 3rd edition. Conservation International Tropical Fieldguide Series.

Ryan, M. \& Kime, N. 2003. Selection on long-distance acoustic signals. Acoustic Communication, 225-274.

Salem, A. H., Ray, D. A. \& Batzer, M. A. 2005. Identity by descent and DNA sequence variation of human SINE and LINE elements. Cytogenetic Genome Research, 108, 63 72.

Salem, A. H., Ray, D. A., Xing, J., Callinan, P. A., Myers, J. S., Hedges, D. J., Garber, R. K., Witherspoon, D. J., Jorde, L. B. \& Batzer, M. A. 2003. Alu elements and hominid phylogenetics. Proceedings of the National Academy of Sciences USA, 22, 12787 12791.

SAMD. 2006. Southeast Asian Mammal Databank.

Sanderson, M. J. 2002. Estimating absolute rates of molecular evolution and divergence times: a penalized likelihood approach. Molecular Biology and Evolution, 19, 101.

Sanderson, M. J. 2003. r8s: inferring absolute rates of molecular evolution and divergence times in the absence of a molecular clock. Bioinformatics, 19, 301.

Schmitz, J., Ohme, M. \& Zischler, H. 2001. SINE insertions in cladistic analyses and the phylogenetic affiliations of Tarsius bancanus to other primates. Genetics, 157, 777 784.

Schmitz, J., Roos, C. \& Zischler, H. 2005. Primate phylogeny: molecular evidence from retroposons. Cytogenetic Genome Research, 108, 26 - 37.

Schneider, C., Hodges, K., Fischer, J. \& Hammerschmidt, K. 2008. Acoustic niches of Siberut primates. International Journal of Primatology, 29, 601-613.

Seehausen, 0. 2004. Hybridization and adaptive radiation. Trends in Ecology \& Evolution, 19, 198 - 207.

Shaw, K. L. 2000. Further acoustic diversity in Hawaiian forests: two new species of Hawaiian cricket (Orthoptera: Gryllidae: Trigonidiinae: Laupala). Zoological Journal of the Linnean Society, 129, 73-91.

Shedlock, A. M. \& Okada, N. 2000. SINE insertions: powerful tools for molecular systematics. Bioessays, 22, 148 - 160. 
Shimodaira, H. \& Hasegawa, M. 1999. Multiple comparisons of log-likelihoods with applications to phylogenetic inference. Molecular Biology and Evolution, 16, 1114 1116.

Smuts, B. B. 1987. Primate societies: University of Chicago Press.

Specht, R. 2011. Avisoft-SASLab Pro sound analysis and synthesis laboratory. In: $R$. Specht, Berlin, Germany.

Steiper, M. E. \& Young, N. M. 2006. Primate molecular divergence dates. Molecular Phylogenetics and Evolution, 41, 384-394.

Sterck, E. H. M., Watts, D. P. \& van Schaik, C. P. 1997. The evolution of female social relationships in nonhuman primates. Behavioral Ecology and Sociobiology, 41, 291309.

Sterck, E. H. M., Willems, E. P., van Hooff, J. A. \& Wich, S. A. 2005. Female dispersal, inbreeding avoidance and mate choice in Thomas langurs (Presbytis thomasi). Behaviour, 142, 845-868.

Sterner, K. N., Raaum, R. L., Zhang, Y. P., Stewart, C. B. \& Disotell, T. R. 2006. Mitochondrial data support an odd-nosed colobine clade. Molecular Phylogenetics and Evolution, 40, 1 - 7.

Stewart, C. B. \& Disotell, T. R. 1998. Primate evolution-in and out of Africa. Current Biology, 8, R582-R588.

Strasser, E. 1992. Hindlimb proportions, allometry, and biomechanics in Old World monkeys (Primates, Cercopithecidae). American journal of physical anthropology, 87, 187-213.

Strasser, E. \& Delson, E. 1987. Cladistic analysis of cercopithecid relationships. Journal of Human Evolution, 16, 81-99.

Stuart, B. L., Rowley, J. J. L., Tran, D., Le, D. T. T. \& Hoang, D. H. 2011. The Leptobrachium (Anura: Megophryidae) of the Langbian Plateau, southern Vietnam, with description of a new species. Zootaxa, 2804, 25-40.

Stünkel, A. 2003. Phylogenie der loud calls der asiatischen Languren (Presbytini), Technische Hochschule.

Swofford, D. L. 2003. PAUP*: Phylogenetic analysis using parsimony (*and other methods), Version 4.0b10.

Szalay, F. S. \& Delson, E. 1979. Evolutionary history of the primates: Academic Press New York.

Talavera, G. \& Castresana, J. 2007. Improvement of phylogenies after removing divergent and ambiguously aligned blocks from protein sequence alignments. Systematic Biology, 56, 564.

Tattersall, I. 2007. Madagascar's lemurs: cryptic diversity or taxonomic inflation? Evolutionary Anthropology: Issues, News, and Reviews, 16, 12-23.

Tenaza, R. 1985. Songs of hybrid gibbons (Hylobates larx H. muelleri). American Journal of Primatology, 8, 249-253.

Thalmann, O., Fischer, A., Lankester, F., Paabo, S. \& Vigilant, L. 2007. The complex evolutionary history of gorillas: insights from genomic data. Molecular Biology and Evolution, 24, 146 - 158. 
Thalmann, O., Hebler, J., Poinar, H. N., Paabo, S. \& Vigilant, L. 2004. Unreliable mtDNA data due to nuclear insertions: a cautionary tale from analysis of humans and other great apes. Molecular Evolution, 13, 321 - 335.

Thinh, V., Hallam, C., Roos, C. \& Hammerschmidt, K. 2011. Concordance between vocal and genetic diversity in crested gibbons. BMC Evolutionary Biology, 11, 36.

Thinh, V. N., Mootnick, A. R., Geissmann, T., Li, M., Ziegler, T., Agil, M., Moisson, P., Nadler, T., Walter, L. \& Roos, C. 2010a. Mitochondrial evidence for multiple radiations in the evolutionary history of small apes. BMC Evolutionary Biology, 10, 74.

Thinh, V. N., Rawson, B., Hallam, C., Kenyon, M., Nadler, T., Walter, L. \& Roos, C. 2010b. Phylogeny and distribution of crested gibbons (genus Nomascus) based on mitochondrial cytochrome b gene sequence data. American Journal of Primatology, 72, 1047 - 1054.

Thorington Jr, R. W. \& Groves, C. P. 1970. An annotated classification of the Cercopithecoidea. In: Old World Monkeys: Ecology, Systematics, and Behavior (Ed. by Napier, J. R. \& Napier, P. H.), pp. 629 - 647. New York: Academic Press.

Tilson, R. L. 1976a. Infant coloration and taxonomic affinity of the Mentawai Islands leaf monkey, Presbytis potenziani. Journal of Mammalogy, 57, 766-769.

Tilson, R. L. 1976b. Monogamy and duetting in an Old World monkey. Nature, 263, 320-321.

Ting, N. 2008. Mitochondrial relationships and divergence dates of the African colobines: evidence of Miocene origins for the living colobus monkeys. Journal of Human Evolution, 55, 312 - 325.

Ting, N., Tosi, A. J., Li, Y., Zhang, Y. P. \& Disotell, T. R. 2008. Phylogenetic incongruence between nuclear and mitochondrial markers in the Asian colobines and the evolution of the langurs and leaf monkeys. Molecular Phylogenetics and Evolution, 46, 466-474.

Tosi, A. J., Detwiler, K. M. \& Disotell, T. R. 2005. X-chromosomal window into the evolutionary history of the guenons (Primates: Cercopithecini). Molecular Phylogenetics and Evolution, 36, 58 - 66.

Tosi, A. J., Morales, J. C. \& Melnick, D. J. 2003. Paternal, maternal, and biparental molecular markers provide unique windows onto the evolutionary history of macaque monkeys. Evolution, 57, 1419 - 1435.

van Bemmelen, R. W. 1970. The geology of Indonesia. Martinus Nijhoff, The Hague, Netherlands.

Van de Lagemaat, L. N., Gagnier, L., Medstrand, P. \& Mager, D. L. 2005. Genomic deletions and precise removal of transposable elements mediated by short identical DNA segments in primates. Genome Research, 15, 1243 - 1249.

van Roosmalen, M. G. M., van Roosmalen, T. \& Mittermeier, R. A. 2002. A taxonomic review of the titi monkeys, genus Callicebus Thomas, 1903, with the description of two new species, Callicebus bernhardi and Callicebus stephennashi, from Brazilian Amazonia. Neotropical Primates, 10.

Vignaud, P., Duringer, P., Mackaye, H. T., Likius, A., Blondel, C., Boisserie, J. R., De Bonis, L., Eisenmann, V., Etienne, M. E., Geraads, D., Guy, F., Lehmann, T., Lihoreau, F., Lopez-Martinez, N., Mourer-Chauvire, C., Otero, O., Rage, J. C., Schuster, M., 
Viriot, L., Zazzo, A. \& Brunet, M. 2002. Geology and palaeontology of the upper Miocene Toros-Menalla hominid locality, Chad. Nature, 418, 152 - 155.

Vun V. F., Mahani M. C., Lakim M., Ampeng A., Md-Zain B. M. 2011: Phylogenetic relationships of leaf monkeys (Presbytis; Colobinae) based on cytochrome $b$ and $12 \mathrm{~S}$ rRNA genes. Genetics \& Molecular Research, 10:368-381.

Waser, P. M. 1975. Experimental playbacks show vocal mediation of intergroup avoidance in a forest monkey. Nature.

Waser, P. M. \& Waser, M. S. 1977. Experimental Studies of Primate Vocalization: Specializations for Long distance Propagation. Zeitschrift für Tierpsychologie, 43, 239-263.

Washburn, S. L. 1944. The genera of Malaysian langurs. Journal of Mammalogy, 25, 289-294.

Watanabe, K. 1981. Variations in group composition and population density of the two sympatric Mentawaian leaf-monkeys. Primates, 22, 145-160.

Weisrock, D. W., Rasoloarison, R. M., Fiorentino, I., Ralison, J. M., Goodman, S. M., Kappeler, P. M. \& Yoder, A. D. 2010. Delimiting species without nuclear monophyly in Madagascar's mouse lemurs. PLoS ONE, 5, e9883.

Weitzel, V., Yang, C. M. \& Groves, C. P. 1988. A catalogue of primates in the Singapore Zoological reference Collection, Department of Zoology, National University of Singapore (Formerly the Zoological Collection of the Raffles Museum). Raffles Bulletin of Zoology, 36, 1 - 166.

Whitfield, L. S., Lovell-Badge, R. \& Goodfellow, P. N. 1993. Rapid sequence evolution of the mammalian sex-determining gene SRY. Nature, 364, 713 - 715.

Whittaker, D. J. 2006. A conservation action plan for the Mentawai primates. Primate Conservation, 95-105.

Whybrow, P. J. 1992. Land movements and species dispersal. In: The Cambridge Encyclopedia of Human Evolution (Ed. by Jones, S., Martin, R., Pilbeam, D. \& Bunney, S.), pp. 169 - 173: Cambridge University Press.

Wich, S. A., Assink, P. R., Becher, F. \& Sterck, E. H. M. 2002a. Playbacks of loud calls to wild Thomas langurs (Primates; Presbytis thomasi): the effect of familiarity. Behaviour, 139, 79-87.

Wich, S. A., Assink, P. R., Becher, F. \& Sterck, E. H. M. 2002b. Playbacks of loud calls to wild Thomas langurs (Primates; Presbytis thomasi): the effect of location. Behaviour, 139, 65-78.

Wich, S. A., Koski, S., de Vries, H. \& van Schaik, C. P. 2003. Individual and Contextual Variation in Thomas Langur Male Loud Calls. Ethology, 109, 1-13.

Wich, S. A. \& Nunn, C. L. 2002. Do male" long-distance calls" function in mate defense? A comparative study of long-distance calls in primates. Behavioral Ecology and Sociobiology, 52, 474-484.

Wich, S. A., Schel, A. M. \& De Vries, H. 2008. Geographic variation in Thomas langur (Presbytis thomasi) loud calls. American Journal of Primatology, 70, 1 - 9.

Wilson, C. C. \& Wilson, W. L. 1976. Behavioral and morphological variation among primate populations in Sumatra. Yearbook of Physical Anthropology, 20, 207-233.

Wilson, W. L. \& Wilson, C. C. 1975. Species-specific vocalizations and the determination of phylogenetic affinities of the Presbytis aygula-melalophos group in Sumatra. In: 
Contemporary Primatology (Ed. by Kondo, S., Kawai, M. \& Ehara, A.), pp. 459-463. Basel: Karger.

Wolfheim, J. H. 1983. Primates of the world: distribution, abundance, and conservation. Cambride: University Press.

World-Bank. 2004. Indonesia at Glance 2004.

<http://siteresources.worldbank.org/INTEEI/Data/20856180/Indonesia.pdf>.

Wyman, S. K., Jansen, R. K. \& Boore, J. L. 2004. Automatic annotation of organellar genomes with DOGMA. Bioinformatics, 20, 3252 - 3255.

Xing, J., Wang, H., Han, K., Ray, D. A., Huang, C. H., Chemnick, L. G., Stewart, C. B., Disotell, T. R., Ryder, O. A. \& Batzer, M. A. 2005. A mobile element based phylogeny of Old World monkeys. Molecular Phylogenetics and Evolution, 37, 872 - 880.

Xing, J., Wang, H., Zhang, Y., Ray, D. A., Tosi, A. J., Disotell, T. R. \& Batzer, M. A. 2007a. A mobile element based evolutionary history of guenons (Tribe Cercopithecini). BMC Biology, 5, 5.

Xing, J., Witherspoon, D. J., Ray, D. A., Batzer, M. A. \& Jorde, L. B. 2007b. Mobile DNA elements in primate and human evolution. American Journal of Physical Anthropology, 45, 2 - 19.

Yang, Z. 2002. Likelihood and Bayes estimation of ancestral population sizes in hominoids using data from multiple loci. Genetics, 162, 1811 - 1823.

Young, N. M. \& MacLatchy, L. 2004. The phylogenetic position of Mortopithecus. Journal of Human Evolution, 46, 163 - 184.

Zalmout, I. S., Sanders, W. J., MacLatchy, L. M., Gunnell, G. F., Al-Mufarreh, Y. A., Ali, M. A., Nasser, A. A. H., Al-Masari, A. M., Al-Sobhi, S. A., Nadhra, A. O., Matari, A. H., Wilson, J. A. \& Gingerich, P. D. 2010. New Oligocene primate from Saudi Arabia and the divergence of apes and Old World monkeys. Nature, 466, 360 - 365.

Zhang, Y. P. \& Ryder, O. A. 1999. Primate evolution - in and out of Africa. Current Biology, 9, R119 - R120.

Ziegler, T., Abegg, C., Meijaard, E., Perwitasari-Farajallah, D., Walter, L., Hodges, J. K. \& Roos, C. 2007. Molecular phylogeny and evolutionary history of Southeast Asian macaques forming the M. silenus group. Molecular Phylogenetics and Evolution, 42, 807 - 816.

Zinner, D., Arnold, M. L. \& Roos, C. 2009a. Is the new primate genus Rungwecebus a baboon? PLOS ONE, 4, e4859.

Zinner, D., Arnold, M. L. \& Roos, C. 2011. The strange blood: Natural hybridization in primates. Evolutionary Anthropology: Issues, News, and Reviews, 20, 96-103.

Zinner, D., Groeneveld, L., Keller, C. \& Roos, C. 2009b. Mitochondrial phylogeography of baboons (Papio spp.)-Indication for introgressive hybridization? BMC Evolutionary Biology, 9, 83.

Zwickl, D. J. 2006. Genetic algorithm approaches for the phylogenetic analysis of large biological sequence data sets under the maximum likelihood criterion. University of Texas, Austin, Thesis. 


\section{Appendix}

Additional File 1: Presencelabsence pattern, location, primers and PCR product sizes of mobile elements.

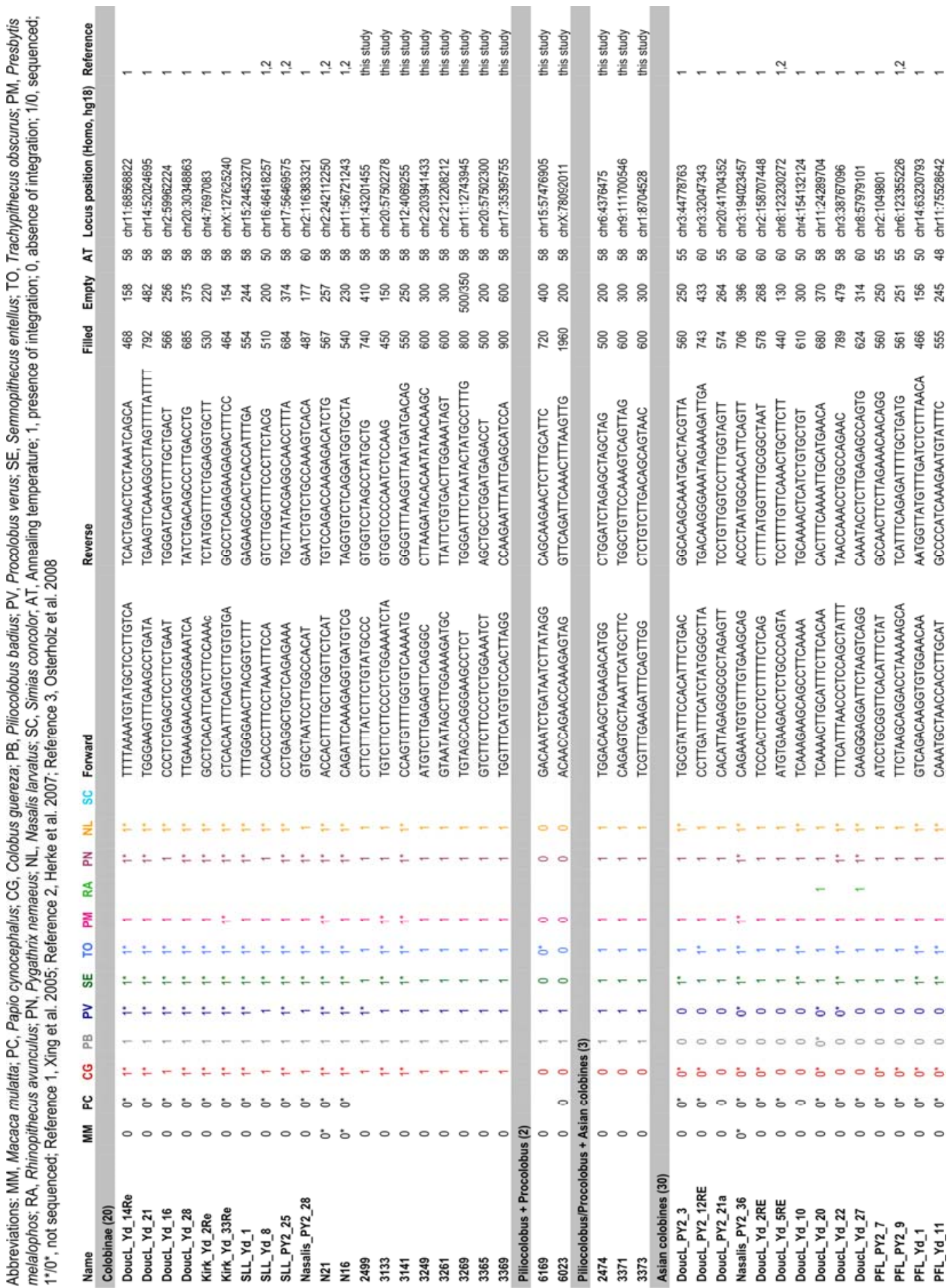


Additonal File 1 continued

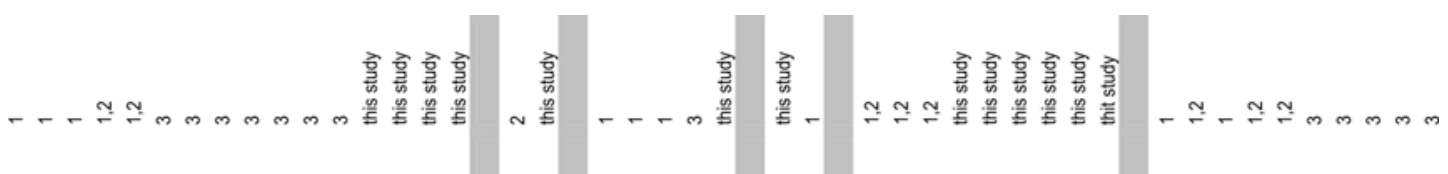

Immmum

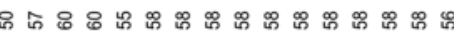

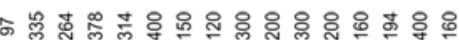

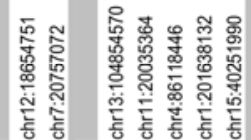

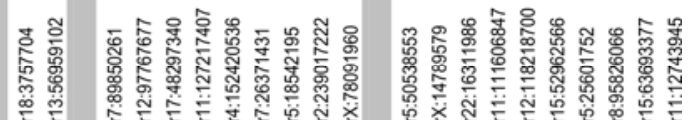

品

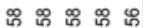

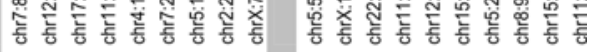

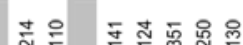

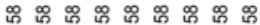

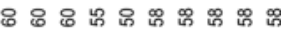

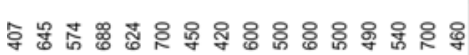

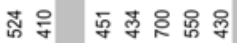

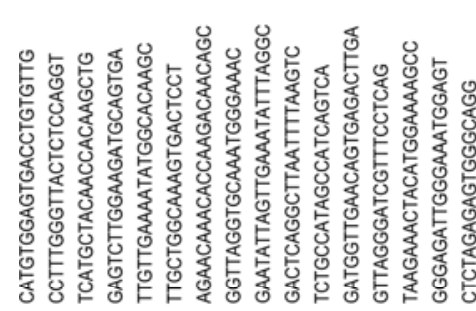

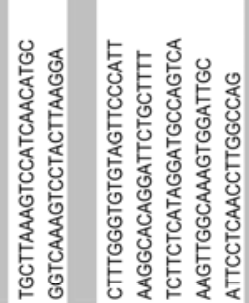

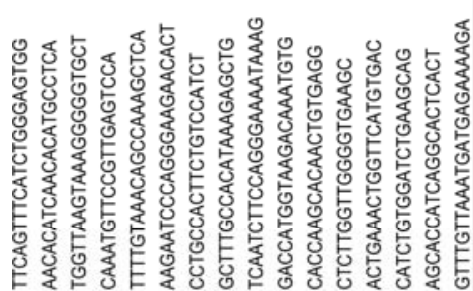

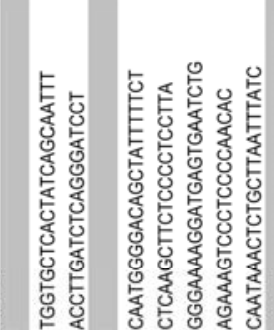

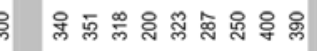

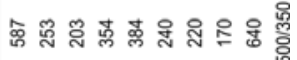

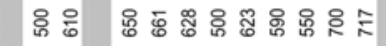

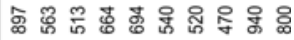

\section{(1)}
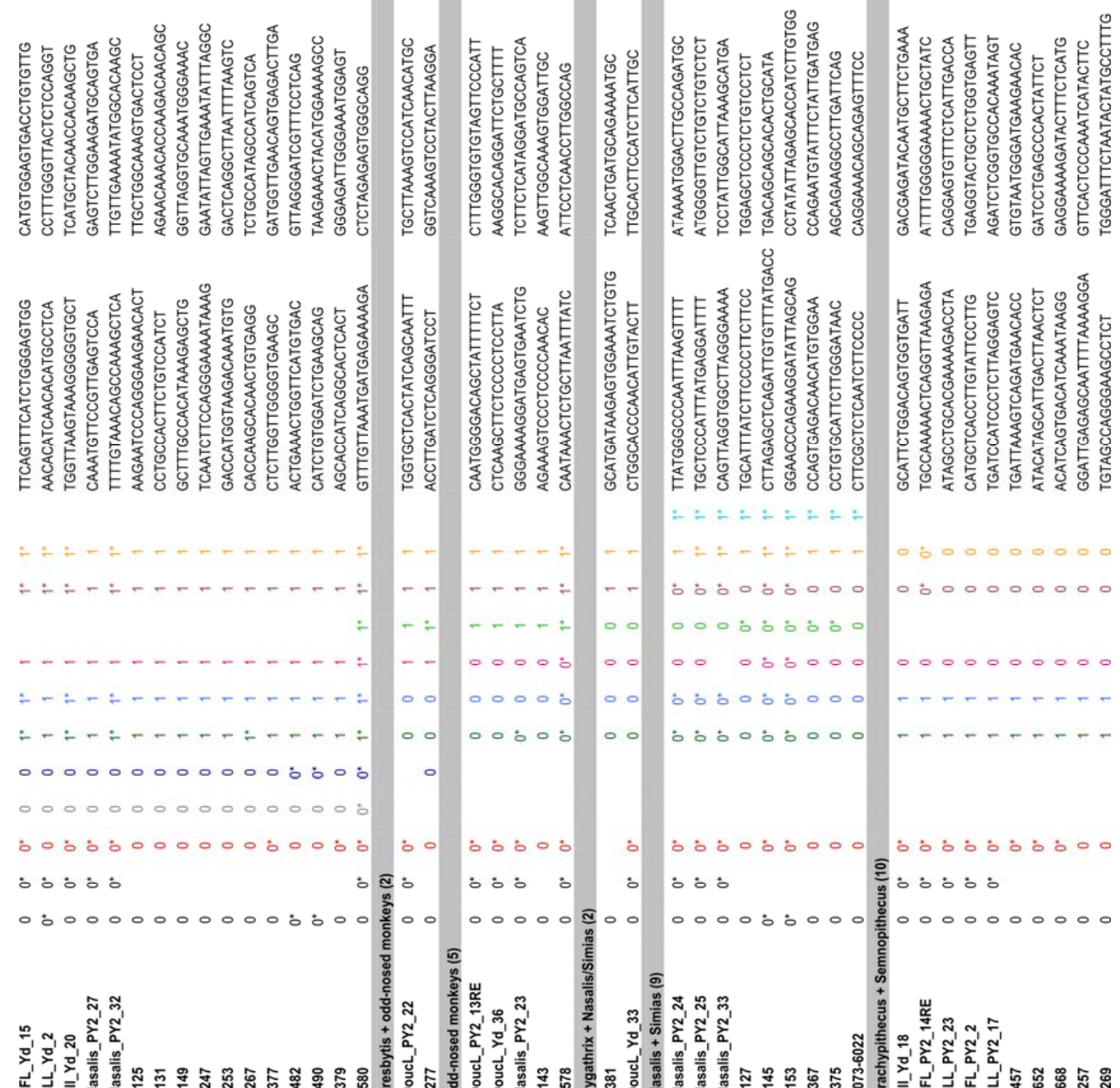

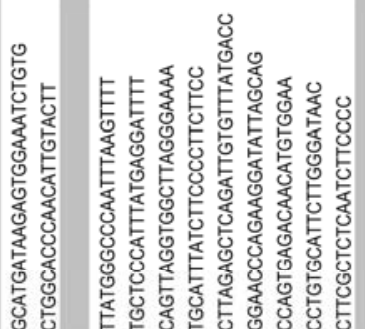

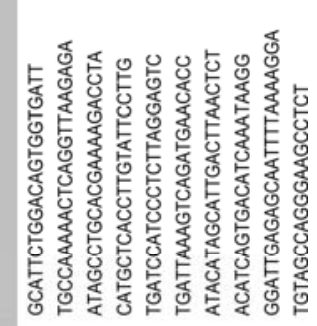

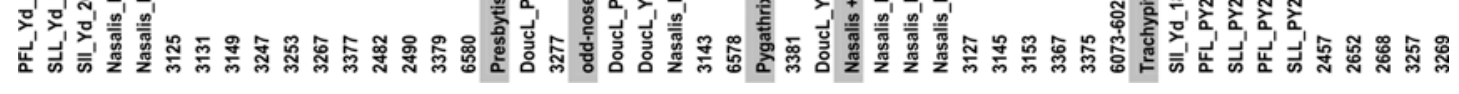


Additional File 2: Primers and PCR conditions for the amplification of nuclear loci.

\begin{tabular}{|c|c|c|c|c|}
\hline Locus & Ref. & Forward primer & Reverse Primer & AT \\
\hline ALB3 & - & $\begin{array}{c}\text { GCATT- } \\
\text { CAAAGTCAACCATG }\end{array}$ & $\begin{array}{c}\text { ACGAA- } \\
\text { GAGTTGCAACTGTGC }\end{array}$ & $56^{\circ} \mathrm{C}$ \\
\hline IRBP3 & - & $\begin{array}{l}\text { CTCTGGACA- } \\
\text { CACGCCCAG }\end{array}$ & $\begin{array}{l}\text { CACACTGCTGGTCA- } \\
\text { GAATGA }\end{array}$ & $58^{\circ} \mathrm{C}$ \\
\hline TNP2 & - & $\begin{array}{l}\text { GCAGGTGTA- } \\
\text { CAAAACCAAG }\end{array}$ & $\begin{array}{c}\text { GTCTCATTAGTTGGATTTC } \\
\text { C }\end{array}$ & $54^{\circ} \mathrm{C}$ \\
\hline TTR1 & - & $\begin{array}{c}\text { GGCCCTACGGTGAG } \\
\text { TGTT }\end{array}$ & $\begin{array}{c}\text { ACTTTGACCATCAGAG- } \\
\text { GACA }\end{array}$ & $56^{\circ} \mathrm{C}$ \\
\hline VWF11 & \multicolumn{4}{|c|}{ Chaves et. al 1999} \\
\hline Xq13.3 & \multicolumn{4}{|c|}{ Ting et al. 2008; Hellborn et al. 2003} \\
\hline DBY5 & \multicolumn{4}{|c|}{ Hellborn et al. 2003} \\
\hline SMCY7 & \multicolumn{4}{|c|}{ Hellborn et al. 2003} \\
\hline SMCY11 & \multicolumn{4}{|c|}{ Hellborn et al. 2003} \\
\hline UTY18 & \multicolumn{4}{|c|}{ Hellborn et al. 2003} \\
\hline SRY & \multicolumn{4}{|c|}{ Whithfield 1993} \\
\hline ZFYLI & - & $\begin{array}{c}\text { CCTGATTCCAGG- } \\
\text { CAGTACC }\end{array}$ & $\begin{array}{c}\text { ATCAGGGCCAATAAT- } \\
\text { TATTGCT }\end{array}$ & $58^{\circ} \mathrm{C}$ \\
\hline
\end{tabular}


Additional File 3: GenBank accession numbers. Sequences in italic are taken from GenBank.

\begin{tabular}{|c|c|c|c|c|c|c|c|c|c|c|c|c|c|c|c|c|c|}
\hline & 茼 & 怤 & 疎 & ז'心 & 芯 & 爱 & 筩 & 㯺 & 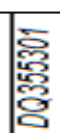 & 总 & 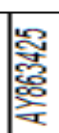 & "ू & 梁 & 屦 & 总 & 崫 & 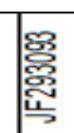 \\
\hline & 产 & 哞 & 萼 & 怘 & 恚 & 爱 & 商 & 尽 & 慧 & 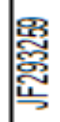 & 芯 & 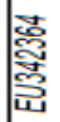 & 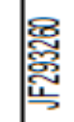 & 竛 & 瓵 & 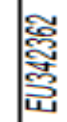 & 倔 \\
\hline & 空 & 溈 & 㤐 & 蕊 & 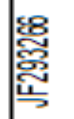 & 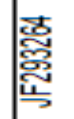 & 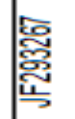 & 剱 & $\begin{array}{l}\text { 芯 } \\
\text { 芯 } \\
\text { 芯 }\end{array}$ & 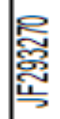 & 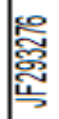 & 㤐 & 镸 & 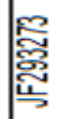 & 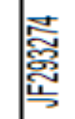 & 芯 & 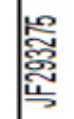 \\
\hline & 㤐 & 璚 & 㚵 & 愛 & 惢 & 梮 & 危 & 䂟 & 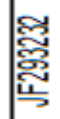 & 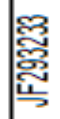 & 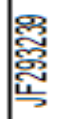 & $\begin{array}{l}\text { 尽 } \\
\text { 总 } \\
\text { 芯 }\end{array}$ & 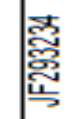 & 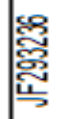 & 芯 & 藋 & 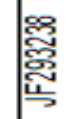 \\
\hline & 蹄 & 慾 & 颜 & 总 & 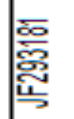 & 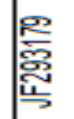 & 嵃 & 怘 & $\begin{array}{l}\text { 总 } \\
\text { 总 } \\
\text { 芩 }\end{array}$ & 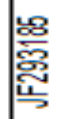 & 离 & 咢 & 舀 & 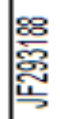 & 䏰 & 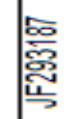 & $\stackrel{\widetilde{I}}{\rightrightarrows}$ \\
\hline 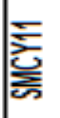 & 虔 & 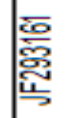 & 若 & 㺃 & 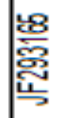 & 离 & 渠 & 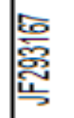 & 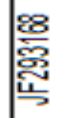 & $\begin{array}{l}\mathscr{B} \\
\text { 总 } \\
\text { 苛 }\end{array}$ & 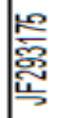 & 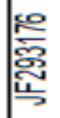 & 尽 & 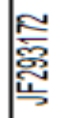 & 䶀 & 㕆 & 空 \\
\hline$?$ & 㢇 & 誉 & 哭 & 总 & 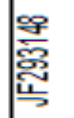 & 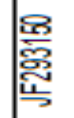 & 言 & 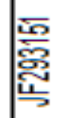 & 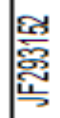 & 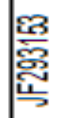 & 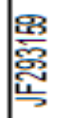 & 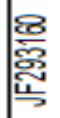 & 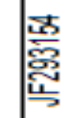 & 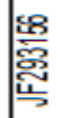 & $\begin{array}{l}\text { 高 } \\
\text { 总 } \\
\text { 空 }\end{array}$ & 将 & 哭 \\
\hline$\Sigma$ & 怼 & 哭 & 悥 & 层 & 曲 & 些 & 竒 & 誉 & 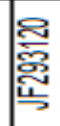 & 彥 & 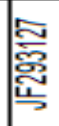 & 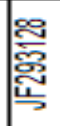 & 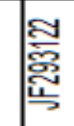 & 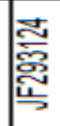 & 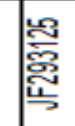 & 芯 & 荶 \\
\hline 5 & 承 & 妾 & 尽 & 吿 & 蕊 & 兽 & 澹 & 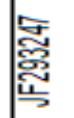 & 哭 & 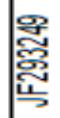 & 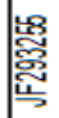 & & 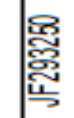 & 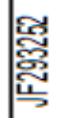 & 怘 & 爱 & \\
\hline $\bar{x}$ & 唯 & 愈 & 危 & 侰 & 莙 & 獄 & 蔚 & 㕍 & 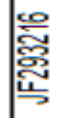 & 詹 & 梮 & 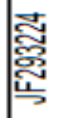 & 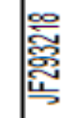 & 貑 & 离 & 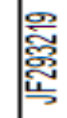 & 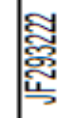 \\
\hline 2 & 滻 & 芯 & 范 & 高 & 澹 & 渠 & 爱 & 急 & 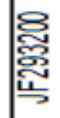 & 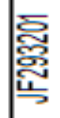 & 詹 & 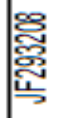 & 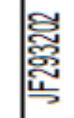 & 泀 & 总 & 空 & 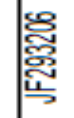 \\
\hline- & 芯 & 㣽 & 危 & 碞 & 蕊 & 慂 & 㺃 & 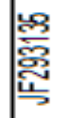 & 恕 & 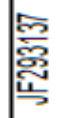 & $\begin{array}{l}\text { 离 } \\
\text { 总 } \\
\text { 苔 }\end{array}$ & 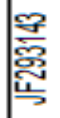 & 竑 & $\begin{array}{l}\text { 荵 } \\
\text { 总 } \\
\text { 范 }\end{array}$ & 离 & 兽 & 芯 \\
\hline 2 & 怘 & 商 & 总 & 总 & 虔 & 啹 & 凷 & 參 & 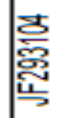 & 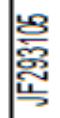 & 㢇 & 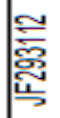 & 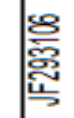 & 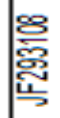 & 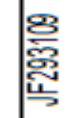 & 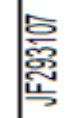 & 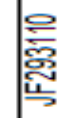 \\
\hline 离 & $\mid \begin{array}{l}\text { 誊 } \\
\text { 产 } \\
\text { 言 }\end{array}$ & 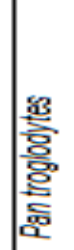 & 罒 & 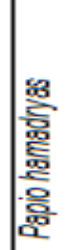 & 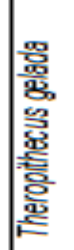 & 誊 & 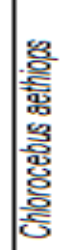 & 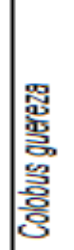 & 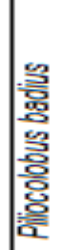 & 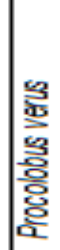 & 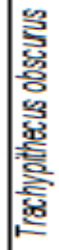 & 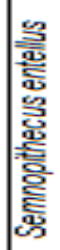 & 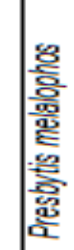 & 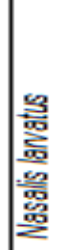 & 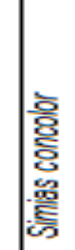 & | & 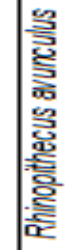 \\
\hline
\end{tabular}


Additional File 4: Single-locus phylogenetic trees ( $80 \%$ majority rule)
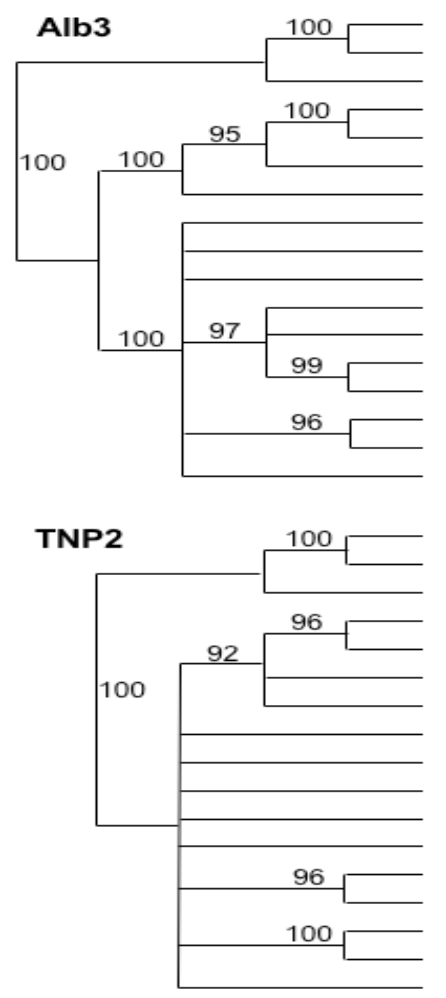

Homo

Pan

Pongo

Papio

Theropithecus

Macaca

Chlorocebus

Colobus

Piliocolobus

Procolobus

Rhinopithecus

Pygathrix

Nasalis

Simias

Trachypithecus

Semnopithecus

Presbytis

Homo

Pan

Pongo

Papio

Theropithecus

Macaca

Chlorocebus

Colobus

Piliocolobus

Procolobus

Rhinopithecus

Pygathrix

Nasalis

Simias

Trachypithecus

Semnopithecus

Presbytis
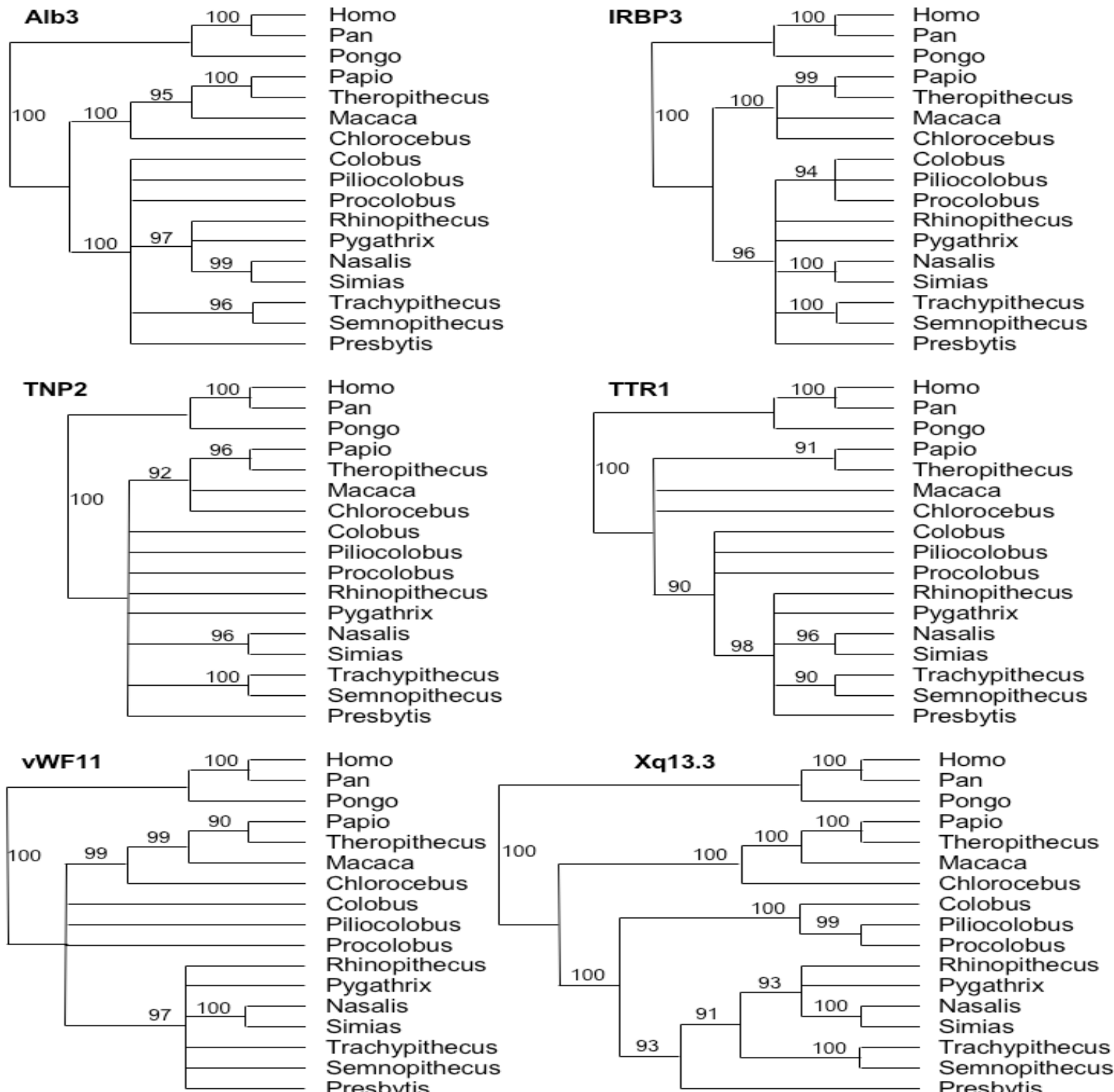


\section{Additional File 5: Divergence ages in mya estimated for each locus separately}

\author{
cercopithecoids-hominoids \\ Pongo-Homo/Pan \\ Homo-Pan \\ cercopithecines-colobines \\ Chlorocebus -other cercopithecines \\ Macaca-Theropithecus/Papio \\ Theropithecus-Papio \\ Colobus -other colobines \\ Procolobus/Piliocolobus-Asian colobines \\ Procolobus-Piliocolobus \\ Asian colobines \\ Semnopithecus-Trachypithecus \\ Presbytis-odd-nosed monkeys \\ odd-nosed monkeys \\ Pygathrix-Nasalis/Simias \\ Nasalis-Simias
}

cercopithecoids-hominoids

Pongo-Homo/Pan

Homo-Pan

cercopithecines-colobines

Chlorocebus -other cercopithecines

Macaca-Theropithecus/Papio

Theropithecus-Papio

Colobus -other colobines

Procolobus/Piliocolobus-Asian colobines

Procolobus-Piliocolobus

Asian colobines

Semnopithecus-Trachypithecus

Presbytis-odd-nosed monkeys

odd-nosed monkeys

Pygathrix-Nasalis/Simias

Nasalis-Simias

\section{Alb3}

$23.45(21.17-25.52)$

$13.81(12.57-14.91)$

$6.48(5.87-7.04)$

$15.45(14.31-16.56)$

$8.93(5.98-12.12)$

$7.12(4.73-9.86)$

$3.88(3.28-4.47)$

$10.87(8.86-12.95)$

$10.26(8.87-12.14)$

$7.67(3.70-11.07)$

$8.73(7.61-9.81)$

$2.99(0.61-5.81)$

$8.04(6.26-9.46)$

$5.20(2.96-7.43)$

$3.13(1.22-5.33)$

$0.36(0.10-1.00)$

DBY5

$23.63(21.44-25.80)$ $13.94(12.74-15.02)$

$6.40(5.83-6.98)$

$15.43(14.32-16.51)$

$9.60(6.72-12.90)$

$7.23(4.82-10-04)$

$3.88(3.27-4.43)$

$10.15(8.40-12.16)$

$9.20(7.79-10.66)$

$2.61(0.27-3.13)$

$8.67(7.58-9.76)$

$1.76(0.26-3.56)$

$7.74(5.92-9.49)$

$6.06(3.99-8.36)$

$5.33(3.07-7.55)$

$1.56(0.27-3.13)$
IRBP3

24.09 (22.08-26.24)

13.87 (12.74-14.97)

$6.41(5.83-6.99)$

15.15 (14.04-16.24)

$8.49(6.17-10.75)$

$6.03(4.46-7.83)$

$3.85(3.28-4.41)$

$10.87(9.28-12.67)$

$10.41(8.84-12.02)$

$7.62(5.00-10.09)$

$8.98(7.88-9.95)$

$3.24(1.58-4.94)$

$8.09(6.66-9.39)$

$5.77(4.10-7.45)$

$5.41(3.76-7.09)$

$2.43(1.07-3.74)$

SMCY7

22.93 (20.53-25.23)

$14.02(12.89-15.21)$

$6.44(5.83-7.03)$

$15.44(14.35-16.63)$

$9.19(5.25-13.01)$

$6.36(4.07-9.45)$

$3.90(3.35-4.49)$

$11.77(9.10-14.51)$

$10.04(8.01-12.48)$

$2.40(0.02-6.34)$

$8.74(7.59-9.86)$

$3.21(0.28-7.04)$

$7.25(4.31-9.84)$

$5.53(2.53-7.84)$

$4.60(1.59-7.90)$

$1.22(0.02-3.13)$
TNP2

23.57 (21.41-25.77)

$13.95(12.79-15.09)$

$6.48(5.92-7.07)$

$15.03(13.83-16.16)$

$9.42(6.07-13.38)$

$7.27(4.60-10.65)$

$3.93(3.37-4.51)$

$13.49(10.97-15.56)$

$12.14(9.79-14.75)$

$6.19(2.51-10.11)$

$9.01(7.93-10.10)$

$1.76(0.21-3.74)$

$7.94(5.90-9.78)$

$5.69(3.21-8.16)$

$4.63(2.24-7.20)$

$1.10(0.03-2.58)$

SMCY11

23.15 (21.04-25.45

$13.94(12.77-15.10$

$6.50(5.93-7.07)$

$15.32(14.20-16.46)$

$8.62(5.16-12.41)$

$7.15(4.22-10.40)$

$3.91(3.35-4.53)$

$11.37(9.11-13.79)$

10.48 (8.54-12.61)

$5.33(1.75-8.90)$

$8.80(7.67-9.85)$

$3.10(0.65-6.03)$

$7.81(5.74-9.60)$

$6.43(3.79-8.71)$

$5.31(2.61-7.87)$

$1.53(0.15-3.31)$ 
Additional File 5 continued

\author{
cercopithecoids-hominoids \\ Pongo-Homo/Pan \\ Homo-Pan \\ cercopithecines-colobines \\ Chlorocebus -other cercopithecines \\ Macaca-Theropithecus/Papio \\ Theropithecus-Papio \\ Colobus -other colobines \\ Procolobus/Piliocolobus-Asian colobines \\ Procolobus-Piliocolobus \\ Asian colobines \\ Semnopithecus-Trachypithecus \\ Presbytis-odd-nosed monkeys \\ odd-nosed monkeys \\ Pygathrix-Nasalis/Simias \\ Nasalis-Simias \\ cercopithecoids-hominoids \\ Pongo-Homo/Pan \\ Homo-Pan \\ cercopithecines-colobines \\ Chlorocebus -other cercopithecines \\ Macaca-Theropithecus/Papio \\ Theropithecus-Papio \\ Colobus -other colobines \\ Procolobus/Piliocolobus-Asian colobines \\ Procolobus-Piliocolobus \\ Asian colobines \\ Semnopithecus-Trachypithecus \\ Presbytis-odd-nosed monkeys \\ odd-nosed monkeys \\ Pygathrix-Nasalis/Simias \\ Nasalis-Simias
}

TTR1

23.49 (21.33-25.77)

$13.98(12.87-15.15)$

$6.44(5.87-7.03)$

$15.37(14.26-16.49)$

$11.76(8.09-15.12)$

$9.54(5.85-13.30)$

$3.95(3.36-4.54)$

$12.96(10.67-15.10)$

$12.26(9.95-14.41)$

$7.52(3.50-11.26)$

$8.56(7.42-9.70)$

$3.37(0.67-6.67)$

$7.22(4.77-9.18)$

$6.26(3.75-8.50)$

$5.41(2.88-7.86)$

$0.51(0.00-1.58)$

\section{SRY}

$23.34(21.27-25.63)$

$13.93(12.82-15.06)$

$6.47(5.86-7.01)$

$15.44(14.35-16.56)$

$9.03(6.20-12.07)$

$5.98(4.18-8.23)$

$3.84(3.26-4.41)$

$10.97(8.99-13.24)$

$10.32(8.40-12.28)$

$4.33(1.09-8.11)$

$8.66(7.62-9.78)$

$3.37(1.14-5.86)$

$7.69(5.71-9.38)$

$6.12(3.72-8.33)$

$5.21(2.57-7.78)$

$1.12(0.03-2.67)$
vWF11

$23.44(21.24-25.73)$

$13.93(12.72-15.01)$

$6.41(5.82-7.01)$

$15.48(14.32-16.56)$

$10.33(7.16-13.40)$

$5.67(3.87-7.78)$

$3.96(3.39-4.53)$

$13.46(11.35-15.48)$

$12.46(10.35-14.67)$

$10.22(7.56-13.02)$

$8.56(7.43-9.64)$

$6.64(3.07-9.22)$

$7.62(5.72-9.33)$

$6.75(4.66-8.91)$

$4.12(1.87-6.37)$

$0.72(0.01-1.81)$

\section{UTY18}

$23.04(20.85-25.35)$

$14.00(12.83-15.15)$

$6.46(5.90-7.08)$

$15.47(14.26-16.54)$

8.57 (4.96-12.29)

$5.59(3.64-8.22)$

$3.92(3.34-4.49)$

$11.46(9.24-13.87)$

$10.76(8.72-13.02)$

$3.86(0.35-8.61)$

$8.58(7.46-9.74)$

$3.03(0.29-6.57)$

7.34 (4.96-9.41)

$5.92(3.22-8.60)$

$4.84(2.03-7.68)$

$0.61(0.00-1.91)$
Xq13.3

$24.12(22.04-26.28)$

$13.82(12.73-14.97)$

$6.43(5.86-7.02)$

$15.47(14.40-16.56)$

$9.78(7.37-12.50)$

$6.65(4.86-8.84)$

$3.83(3.25-4.39)$

$10.80(9.14-12.34)$

10. $57(9.01-12.14)$

6.94 (4.17-9.63)

$8.35(7.25-9.36)$

$2.02(0.70-3.64)$

$7.96(6.71-9.27)$

$6.28(4.26-8.08)$

$5.93(3.87-7.83)$

$1.13(0.28-2.23)$

\section{ZFYLI}

23.23 (21.11-25.43)

$14.13(12.99-15.24)$

$6.39(5.79-6.97)$

15.38 (14.28-16.51)

$10.20(6.86-13.25)$

$6.07(3.96-8.61)$

$3.92(3.32-4.46)$

$11.96(9.73-14.26)$

$11.24(9.19-13.52)$

$6.46(2.72-10.35)$

8.67 (7.55-9.77)

$2.66(0.21-5.89)$

$7.81(6.02-9.52)$

$6.53(4.11-8.65)$

$4.14(1.84-6.49)$

$1.00(0.02-2.37)$ 
Additional File 6: Descriptive statistics to the measured parameters.

\begin{tabular}{|c|c|c|c|c|c|c|c|c|c|c|}
\hline \multirow[b]{2}{*}{ number } & \multirow[b]{2}{*}{ Parameter } & \multicolumn{3}{|c|}{ Presbytis comata } & \multicolumn{3}{|c|}{ Presbytis m. mitrata } & \multicolumn{3}{|c|}{ Presbytis m.melalophos } \\
\hline & & $\begin{array}{c}\text { arithmetic } \\
\text { mean }\end{array}$ & $\begin{array}{l}\text { standard } \\
\text { derivation }\end{array}$ & $\mathrm{n}$ & $\begin{array}{l}\text { arithmetic } \\
\text { mean }\end{array}$ & $\begin{array}{c}\text { standard } \\
\text { derivation }\end{array}$ & $\mathbf{n}$ & $\begin{array}{l}\text { arithmetic } \\
\text { mean }\end{array}$ & $\begin{array}{c}\text { standard } \\
\text { derivation }\end{array}$ & $\mathrm{n}$ \\
\hline 1 & Tduration & 2,86 & .26 & 10 & 2,38 & .33 & 19 & 2,41 & .50 & 28 \\
\hline 2 & Elements & 52 & 8 & 10 & 28 & 6 & 18 & 20 & 4 & 28 \\
\hline 3 & elemente/s & 18.20 & 1,81 & 10 & 10,85 & 2,36 & 18 & 8,28 & 1.05 & 28 \\
\hline 4 & $f \max s$ & 5537 & 1385 & 10 & 4732 & 623 & 19 & 5132 & 837 & 28 \\
\hline 5 & $f \min s$ & 759 & 322 & 10 & 2103 & 1089 & 18 & 2803 & 1184 & 28 \\
\hline B & $f \max e$ & 5604 & 1370 & 10 & 3665 & 1028 & 19 & 2428 & 821 & 28 \\
\hline 7 & fmin $e$ & 1076 & 328 & 10 & 812 & 401 & 18 & 1180 & 324 & 28 \\
\hline 8 & fmean $\mathrm{s}$ & 1695 & 469 & 10 & 3429 & 869 & 18 & 4189 & 832 & 28 \\
\hline 8 & fmean e & 2289 & 355 & 10 & 1715 & 303 & 19 & 1530 & 253 & 28 \\
\hline 10 & EX & 29 & 4 & 10 & 20 & 3 & 18 & 19 & 4 & 29 \\
\hline 11 & IN & 24 & 4 & 10 & 6 & 5 & 19 & 1 & 2 & 28 \\
\hline 12 & $1 / 4$ t/e & .05 & .01 & 10 & .09 & .01 & 19 & .09 & .01 & 28 \\
\hline 13 & $2 / 4$ t/e & .04 & .01 & 10 & .09 & .02 & 19 & .10 & .01 & 29 \\
\hline 14 & $3 / 4$ t/e & .05 & .01 & 10 & .09 & .03 & 18 & .12 & .02 & 28 \\
\hline 15 & $4 / 4$ t/e & .07 & .02 & 10 & .11 & .04 & 18 & .14 & .02 & 28 \\
\hline 16 & middle $(2 / 4-3 / 4)$ tee & .04 & .01 & 10 & .09 & .02 & 19 & .12 & .02 & 28 \\
\hline 17 & 1/4 mean $f$ start EX & 1316 & 196 & 10 & 3227 & 798 & 18 & 3566 & 794 & 28 \\
\hline 18 & 2/4 mean $\mathrm{f}$ start EX & 1394 & 221 & 10 & 3585 & 742 & 19 & 4132 & 833 & 28 \\
\hline 18 & 3/4 mean $f$ start EX & 1504 & 186 & 10 & 3799 & 709 & 18 & 4434 & 893 & 28 \\
\hline 20 & 4/4 mean f start EX & 3774 & 1103 & 10 & 4282 & 569 & 18 & 4849 & 798 & 28 \\
\hline 21 & $\begin{array}{l}\text { middle }(2 / 4-3 / 4) \text { mean } \\
\text { f start EX }\end{array}$ & 1452 & 196 & 10 & 3692 & 718 & 19 & 4280 & 859 & 28 \\
\hline 22 & $1 / 4$ mean $f$ end $E X$ & 1539 & 168 & 10 & 1571 & 294 & 18 & 1534 & 326 & 28 \\
\hline 23 & 2/4 mean $f$ end EX & 1768 & 232 & 10 & 1244 & 404 & 19 & 1399 & 261 & 28 \\
\hline 24 & 3/4 mean $f$ end $E X$ & 1990 & 188 & 10 & 1071 & 428 & 19 & 1382 & 309 & 28 \\
\hline 25 & 4/4 mean $f$ end $E X$ & 4284 & 959 & 10 & 1851 & 391 & 18 & 1728 & 362 & 28 \\
\hline 28 & $\begin{array}{l}\text { middle }(2 / 4-3 / 4) \text { mean } \\
f \text { end } E X\end{array}$ & 1880 & 168 & 10 & 1155 & 392 & 19 & 1394 & 272 & 28 \\
\hline 27 & first min & 1120 & 166 & 10 & 1727 & 531 & 19 & 1736 & 801 & 28 \\
\hline 28 & first fundamental & 1547 & 141 & 10 & 2274 & 680 & 19 & 2749 & 1011 & 28 \\
\hline 29 & first max & 2401 & 707 & 10 & 2987 & 732 & 18 & 3604 & 812 & 28 \\
\hline 30 & middle min & 1262 & 348 & 10 & 1573 & 259 & 18 & 1532 & 195 & 28 \\
\hline 31 & middle fund & 1778 & 235 & 10 & 2304 & 710 & 19 & 2402 & 905 & 28 \\
\hline 32 & middle $\max$ & 2961 & 1055 & 10 & 3371 & 653 & 19 & 4034 & 1025 & 28 \\
\hline 33 & last min & 4845 & 1413 & 10 & 2109 & 569 & 19 & 2181 & 658 & 28 \\
\hline 34 & last fund & 5273 & 1417 & 10 & 3717 & 901 & 19 & 3366 & 1250 & 28 \\
\hline 35 & last max & 5833 & 1464 & 10 & 4636 & 687 & 19 & 4701 & 1234 & 29 \\
\hline 36 & dif min start min end & 4057 & 1291 & 10 & 379 & 763 & 19 & 392 & 843 & 28 \\
\hline 37 & dif mid fund mid end & 3881 & 1453 & 10 & 1443 & 1235 & 18 & 514 & 1649 & 28 \\
\hline 38 & dif $\max$ start max end & 3672 & 1588 & 10 & 1848 & 896 & 19 & 881 & 1284 & 28 \\
\hline 39 & mean beginning & 1720 & 268 & 10 & 2330 & 594 & 18 & 2814 & 881 & 28 \\
\hline 40 & mean middle & 2000 & 287 & 10 & 2416 & 436 & 19 & 2856 & 592 & 28 \\
\hline 41 & mean end & 5365 & 1420 & 10 & 3428 & 487 & 19 & 3420 & 798 & 28 \\
\hline 42 & $(e x+1) /($ in +1$)$ start & 2,04 & 2,47 & 10 & 5.87 & 1,31 & 19 & 6,00 & 1,07 & 28 \\
\hline 43 & $(e x+1) /(\mathrm{in}+1)$ middle & 1,01 & .04 & 10 & 5,09 & 4,50 & 19 & 8,93 & 3,12 & 28 \\
\hline 44 & $(e x+1) /(i n+1)$ end & 1,83 & .59 & 10 & 2,86 & 2,28 & 18 & 5,30 & 1,55 & 28 \\
\hline
\end{tabular}


Additional File 5 continued

\begin{tabular}{|c|c|c|c|c|c|c|c|c|c|c|c|}
\hline \multicolumn{3}{|c|}{ Presbytis m.bicolor } & \multicolumn{3}{|c|}{ Presbytis m.sumatrana } & \multicolumn{3}{|c|}{ Presbytis potenziani } & \multicolumn{3}{|c|}{ Presbytis thomasi } \\
\hline $\begin{array}{l}\text { arithmetic } \\
\text { mean }\end{array}$ & $\begin{array}{c}\text { standard } \\
\text { derivation }\end{array}$ & $\mathbf{n}$ & $\begin{array}{l}\text { arithmetic } \\
\text { mean }\end{array}$ & $\begin{array}{c}\text { standard } \\
\text { derivation }\end{array}$ & $\mathrm{n}$ & $\begin{array}{c}\text { arithmetic } \\
\text { mean }\end{array}$ & $\begin{array}{l}\text { standard } \\
\text { derivation }\end{array}$ & $\mathbf{n}$ & $\begin{array}{c}\text { arithmetic } \\
\text { mean }\end{array}$ & $\begin{array}{c}\text { standard } \\
\text { derivation }\end{array}$ & $\mathbf{n}$ \\
\hline 2,52 & .53 & 15 & 2,53 & .40 & 8 & 4,17 & .42 & 8 & 3,58 & .35 & 10 \\
\hline 19 & 4 & 15 & 19 & 3 & 8 & 27 & 2 & 8 & 30 & 4 & 10 \\
\hline 7,35 & .40 & 15 & 7.45 & .18 & 8 & 6.42 & .56 & 8 & 8,50 & 1,00 & 10 \\
\hline 7587 & 2685 & 15 & 7006 & 845 & 8 & 1757 & 113 & 8 & 1752 & 228 & 10 \\
\hline 4627 & 2328 & 15 & 4296 & 1368 & 8 & 517 & 454 & 9 & 409 & 65 & 10 \\
\hline 2609 & 1132 & 15 & 1730 & 277 & 8 & 1779 & 155 & 8 & 1785 & 122 & 10 \\
\hline 1857 & 439 & 15 & 979 & 164 & 8 & 540 & 486 & 9 & 376 & 84 & 10 \\
\hline 6484 & 2492 & 15 & 5837 & 788 & 8 & 1119 & 228 & 9 & 972 & 171 & 10 \\
\hline 2098 & 792 & 15 & 1279 & 90 & 8 & 1115 & 271 & 9 & 993 & 86 & 10 \\
\hline 19 & 4 & 15 & 19 & 3 & 8 & 13 & 1 & 9 & 18 & 3 & 10 \\
\hline 0 & 0 & 15 & 0 & 0 & 8 & 13 & 1 & 9 & 12 & 2 & 10 \\
\hline . 10 & .01 & 15 & .09 & .00 & 8 & .16 & .02 & 9 & .08 & .01 & 10 \\
\hline .12 & .01 & 15 & 11 & .00 & 8 & .21 & .02 & 9 & .11 & .02 & 10 \\
\hline .13 & .01 & 15 & .13 & .00 & 8 & 14 & .02 & 9 & 14 & .02 & 10 \\
\hline .14 & .01 & 15 & 16 & .01 & 8 & 10 & .01 & 9 & 12 & .02 & 10 \\
\hline .14 & .01 & 15 & 13 & .00 & 8 & 17 & .03 & 9 & .12 & .02 & 10 \\
\hline 5691 & 2425 & 15 & 5088 & 878 & 8 & 1445 & 108 & 9 & 1199 & 395 & 10 \\
\hline 6627 & 2698 & 15 & 5560 & 813 & 8 & 1554 & 93 & 8 & 1409 & 295 & 10 \\
\hline 6880 & 2695 & 15 & 6031 & 765 & 8 & 870 & 246 & 9 & 1076 & 319 & 10 \\
\hline 6732 & 2386 & 15 & 6719 & 1038 & 8 & 449 & 14 & 9 & 495 & 54 & 10 \\
\hline 6741 & 2688 & 15 & 5803 & 678 & 8 & 1205 & 159 & 9 & 1250 & 304 & 10 \\
\hline 2206 & 1002 & 15 & 1400 & 234 & 8 & 1482 & 158 & 8 & 1274 & 411 & 10 \\
\hline 2143 & 1035 & 15 & 1282 & 161 & 8 & 1504 & 185 & 9 & 1508 & 198 & 10 \\
\hline 2053 & 689 & 15 & 1187 & 41 & 8 & 887 & 208 & 9 & 1073 & 223 & 10 \\
\hline 1984 & 488 & 15 & 1252 & 43 & 8 & 448 & 14 & 9 & 470 & 54 & 10 \\
\hline 2088 & 844 & 15 & 1229 & 81 & 8 & 1190 & 81 & 9 & 1299 & 178 & 10 \\
\hline 1993 & 451 & 15 & 1507 & 218 & 8 & 1218 & 339 & 8 & 773 & 360 & 10 \\
\hline 3081 & 1873 & 15 & 2253 & 598 & 8 & 1609 & 140 & 9 & 1561 & 262 & 10 \\
\hline 4949 & 2547 & 15 & 3623 & 997 & 8 & 2382 & 428 & 9 & 2279 & 409 & 10 \\
\hline 2100 & 389 & 15 & 1803 & 269 & 8 & 872 & 386 & 8 & 1084 & 299 & 10 \\
\hline 3298 & 1802 & 15 & 2217 & 171 & 8 & 1888 & 152 & 9 & 1838 & 221 & 10 \\
\hline 4478 & 2543 & 15 & 3841 & 673 & 8 & 2844 & 299 & 8 & 2382 & 395 & 10 \\
\hline 2080 & 340 & 15 & 2224 & 485 & 8 & 361 & 32 & 9 & 373 & 96 & 10 \\
\hline 3503 & 2307 & 15 & 2877 & 412 & 8 & 457 & 22 & 9 & 484 & 55 & 10 \\
\hline 4948 & 2331 & 15 & 5180 & 1773 & 8 & 564 & 63 & 8 & 633 & 160 & 10 \\
\hline-190 & 797 & 15 & 770 & 595 & 8 & -856 & 336 & 9 & -324 & 452 & 10 \\
\hline-45 & 1171 & 15 & 624 & 417 & 8 & -1151 & 132 & 8 & -921 & 552 & 10 \\
\hline 285 & 1243 & 15 & 1557 & 2234 & 8 & -1818 & 448 & 9 & -1418 & 820 & 10 \\
\hline 3279 & 1467 & 15 & 2309 & 288 & 8 & 1738 & 150 & 9 & 1538 & 183 & 10 \\
\hline 3292 & 1500 & 15 & 2554 & 228 & 8 & 1801 & 162 & 9 & 1701 & 158 & 10 \\
\hline 3510 & 1523 & 15 & 3427 & 694 & 8 & 461 & 25 & 9 & 497 & 52 & 10 \\
\hline 5,80 & .84 & 15 & 5,88 & .83 & 8 & .87 & .10 & 8 & 5,27 & 1,84 & 10 \\
\hline 10.27 & 2,19 & 15 & 10,50 & 1,31 & 8 & 1.03 & .07 & 9 & 1,31 & .26 & 10 \\
\hline 5.47 & 1,19 & 15 & 5,50 & .93 & 8 & 1.13 & .20 & 9 & 1,09 & .11 & 10 \\
\hline
\end{tabular}


Additional File 7: Photographs of Presbytis taxa.

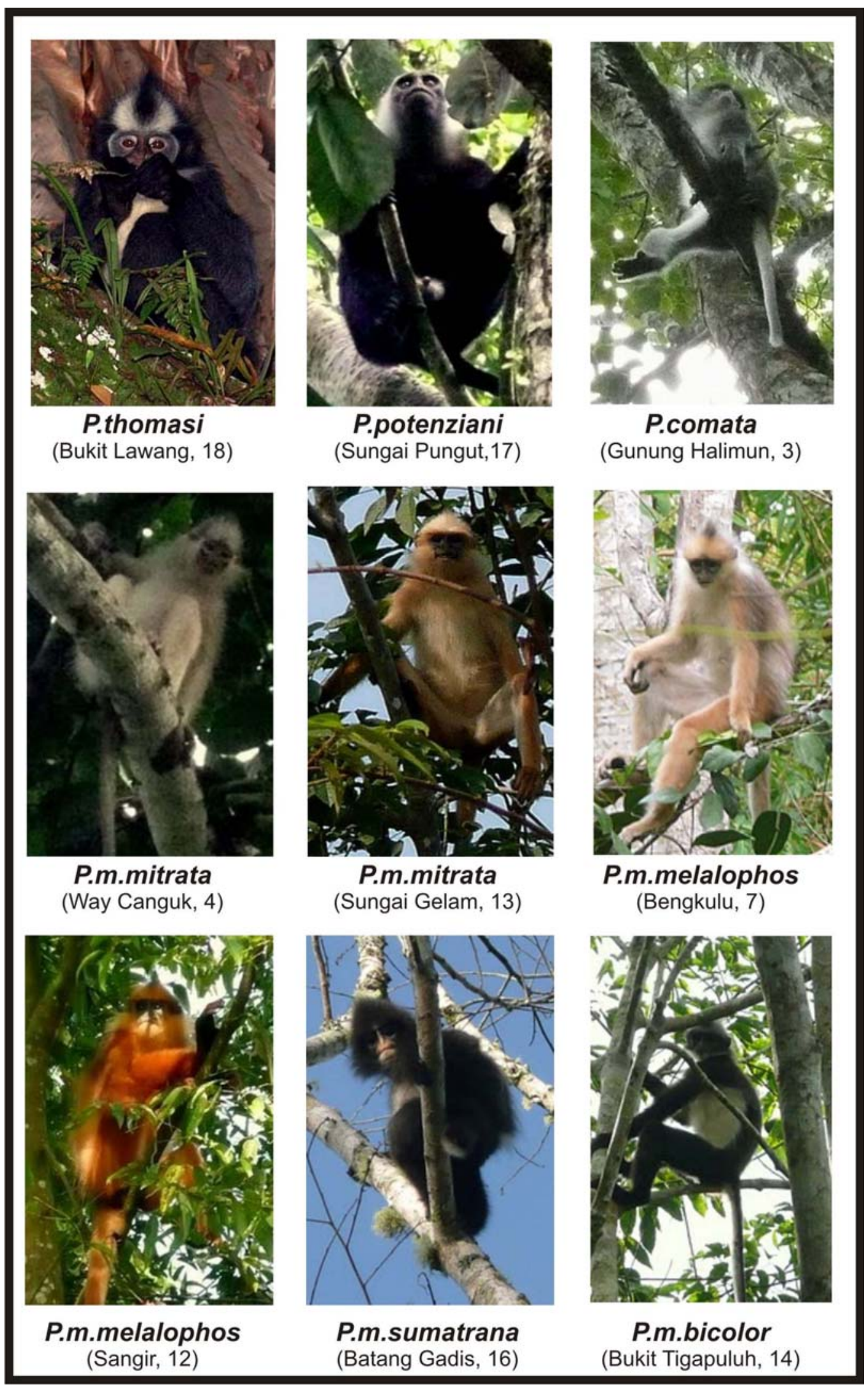




\section{Danksagung}

Ich bedanke mich bei...

Keith Hodges, für die gute Betreuung und viele lehrreiche Hinweise, welche mir nicht nur bei der Erstellung dieser Arbeit sehr geholfen, sondern auch zu meiner persönlichen Weiterentwicklung beigetragen haben (für einige graue Haare bin sicherlich ich verantwortlich....),

Muhammad Agil, Rinekso Soekmadi und Dones Rinaldi, meinen indonesischen Partnern vom Institut Pertanian Bogor (IPB), für die Hilfe vor Ort und die Unterstützung die Riesenmengen von Permits zu erlangen,

Christian Roos, für die große Hilfe bei der Laborarbeit, eine Engelsgeduld und viele tolle Grillabende mit gutem bayerischem Bier,

Insan Kurnia und vor allem Ambang Wijaya, meinen Feldassistenten, ohne sie wäre die Feldarbeit in Indonesien noch komplizierter gewesen, als sie schon war,

Lena Bruhn und Florian Voss, für das Korrekturlesen der Arbeit,

Stephen D. Nash, für die Genehmigung seine tollen Illustrationen in der Arbeit zu benutzen,

Kurt Hammerschmidt, für sehr anregende Diskussionen und die große Unterstützung bei der Interpretation der Daten,

Dietmar Zinner, für die Hilfe bei der Erstellung von Verbreitungskarten mit ArcGis,

Christian Matauschek, für ....... (da reicht der Platz nicht) ...alles..., aber vor allem dafür, daß er immer für mich da war,

der Abteilung Reproduktionbiologie, für eine nette Zusammenarbeit,

und allen Freunden und Kollegen, für Motivation und nicht zu vergessen zahlreichen die Reisen nach "Neverland“, besonders Ellen Wiese, Petra Kiesel, Yvan Lledo-Ferrer (the beaver), Mojca Stojan-Dolar, Vanessa Mass, "Muschi-Katze" Sabine Hutschenreuther (vor allem auch für die riesige Hilfe beim Formatieren), Matthias Markolf, Susanne Schliehe-Dieks, Markus Port, Tanja Wolf, Tanja Haus, Gisela Fickenscher, "Prof. Dr. Hong" Thinh van Ngoc, Rodrigo Soria-Auza (the beaver), Oda Hölscher, Anne Neurath und Jan Weckwerth (the beaver).........

Katrin Paetzold, für ihre große Geduld und Unterstützung, sowie Jone Josephine Wotschke, ohne die ich niemals auf den „Affen“ gekommen wäre,

Und vor allem meinen Eltern, ohne deren andauernde Unterstützung diese Arbeit nicht möglich gewesen wäre. 


\section{Curriculum Vitae}

\section{Persönliche Daten}

Dirk Meyer - Diplom-Biologe

geboren am 13. März 1970 in Berlin

ledig, eine Tochter

Rembrandtstr.16

12157 Berlin

E-Mail: dirk.meyer@redape.de

\section{Studium und berufliche Entwicklung}

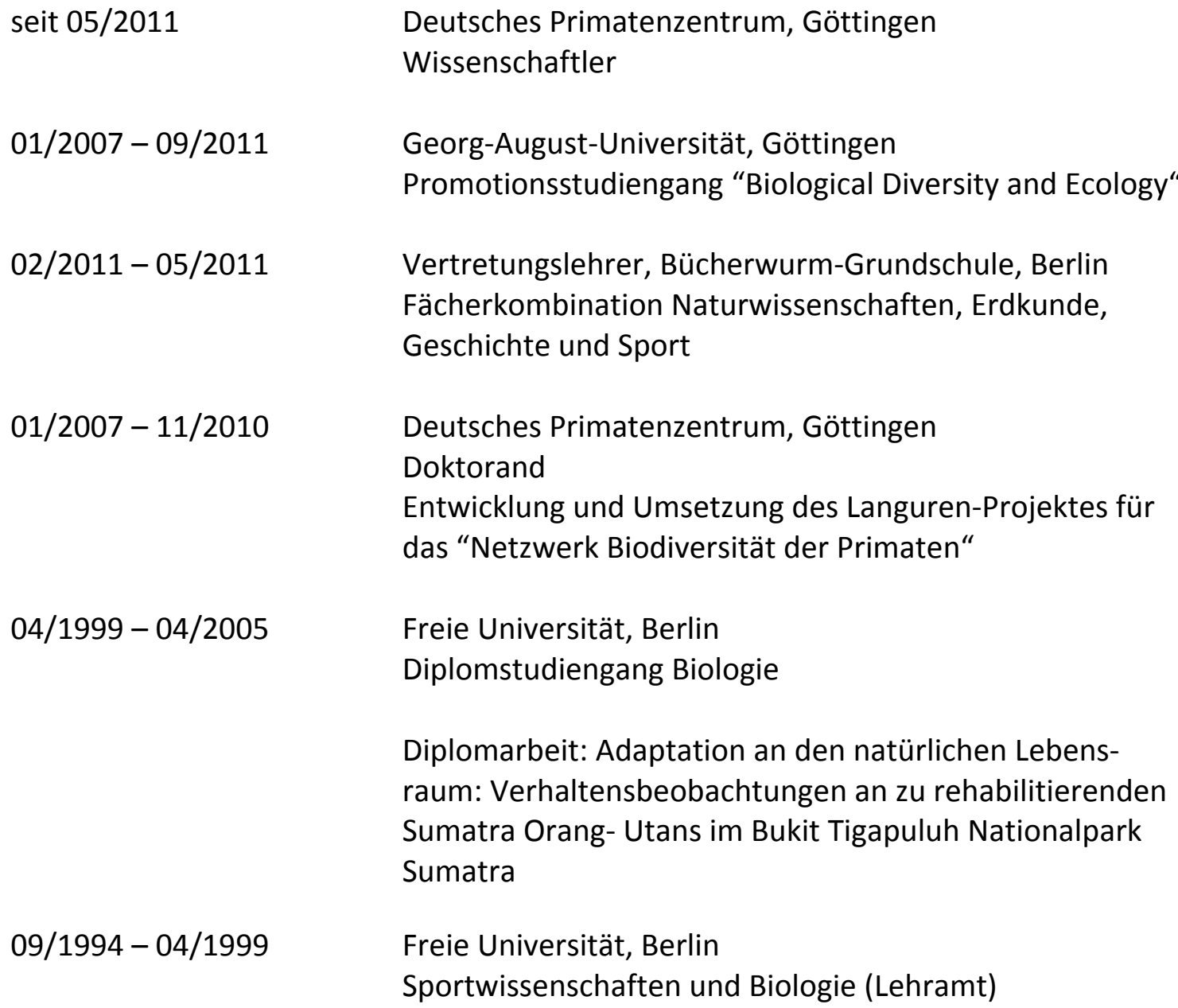


09/1989-08/1991 Freie Universität, Berlin

Chemie und Geographie (Lehramt)

08/1991-07/1994

Lise-Meitner Schule, Berlin

Ausbildung zum Biologisch-Technischen-Assistenten (BTA)

05/1989

Rückert Gymnasium, Berlin

Abitur

\section{Auszeichnungen}

$08 / 2009$

Zürich, 3. Kongress der Europäischen Föderation für Primatologie

1. Preis für den besten Vortrag von Nachwuchswissenschaftlern (EFP Folia Primatologica Young Scientist Award)

\section{Publikationen}

Meyer, D., Hodges, J., Rinaldi, D., Wijaya, A., Roos, C. \& Hammerschmidt, K. (2012): Acoustic structure of male loud-calls support molecular phylogeny of Sumatran and Javanese leaf monkeys (genus Presbytis). BMC Evol Biol 12: 16. doi:10.1186/14712148-12-16.

Meyer D., Dones Rinaldi IR., Ramlee H., Perwitasari-Farajallah D., Hodges K.J. and Roos C., (2011): Mitochondrial phylogeny of leaf monkeys (genus Presbytis, Eschscholtz, 1821) with implications for taxonomy and conservation. Molecular Phylogenetics and Evolution, Vol.59, pp. 311-319. http://dx.doi.org/10.1016/j.ympev.2011.02.015.

Roos C., Zinner D., Kubatko L.S., Schwarz C., Yang M., Meyer D., Nash S.D., Xing J., Batzer M.A., Brameier M., Leendertz F.H., Ziegler T., Perwitasari-Farajallah D., Nadler T., Walter L., Osterholz M. (2011): Nuclear versus mitochondrial DNA: evidence for hybridization in colobine monkeys. BMC Evolutionary Biology 11: 77.

Meyer D., Roos C. Hodges J.K. (2009): Molecular Phylogeny and Biogeography of Leaf Monkeys (genus Presbytis). 3rd Congress of the European Federation for Primatology, Abstracts. Folia Primatologica 80, pp. 130. 


\section{Eidesstattliche Erklärung}

Ich erkläre hiermit, dass ich diese Dissertation selbstständig ohne Hilfe Dritter und ohne Benutzung anderer als der angegebenen Quellen und Hilfsmittel verfasst habe. Alle den benutzten Quellen wörtlich oder sinngemäß entnommenen Stellen sind als solche einzeln kenntlich gemacht. Eigene Beiträge, im Verhältnis zu denen von Koautoren bei bereits publizierten oder zur Publikation eingereichten Teilen dieser Arbeit sind wie folgt:

Kapitel 2: Die Laborarbeit wurde von Dirk Meyer, Christian Roos, Martin Osterholz, Mouya Yang und Cristiane Schwarz ausgeführt. Für die Datenauswertung, sowie die Erstellung des Manuskriptes waren im wesentlichen Christian Roos und Martin Osterholz verantwortlich.

Kapitel 3: Die Studie wurde von Dirk Meyer, Christian Roos und Keith Hodges geplant. Die Proben wurden von Dirk Meyer mit Unterstützung von Ambang Wijaya gesammelt. Die Laborarbeit, sowie die Datenauswertung wurden von Dirk Meyer ausgeführt. Das Manuskript wurde von Dirk Meyer in Rücksprache mit Christian Roos und Keith Hodges erstellt.

Kapitel 4: Die Studie wurde von Dirk Meyer, Keith Hodges und Kurt Hammerschmidt geplant. Die Proben wurden von Dirk Meyer mit Unterstützung von Ambang Wijaya gesammelt. Die Laborarbeit wurde von Dirk Meyer ausgeführt. Die Datenauswertung wurde von Dirk Meyer in Rücksprache mit Kurt Hammerschmidt ausgeführt. Das Manuskript wurde von Dirk Meyer in Rücksprache mit Christian Roos, Keith Hodges und Kurt Hammerschmidt verfaßt.

Die Übersetzungen der Summary und der Abstracts der einzelnen Publikationen in das Indonesische wurden von Dones Rinaldi, bzw. Ambang Wijaya übernommen.

Diese Arbeit ist bislang keiner anderen Prüfungsbehörde vorgelegt worden und auch nicht veröffentlicht worden. Ich bin mir bewusst, dass eine falsche Erklärung rechtliche Folgen haben wird.

Ort, Datum, Unterschrift 